\title{
Political Beings: Sociopolitical Influence on Federal District Court Judges' Criminal Sentencing Behavior
}

\author{
Scott Harris
}

Follow this and additional works at: https://researchrepository.wvu.edu/etd

\section{Recommended Citation}

Harris, Scott, "Political Beings: Sociopolitical Influence on Federal District Court Judges' Criminal Sentencing Behavior" (2016). Graduate Theses, Dissertations, and Problem Reports. 5770.

https://researchrepository.wvu.edu/etd/5770

This Dissertation is protected by copyright and/or related rights. It has been brought to you by the The Research Repository @ WVU with permission from the rights-holder(s). You are free to use this Dissertation in any way that is permitted by the copyright and related rights legislation that applies to your use. For other uses you must obtain permission from the rights-holder(s) directly, unless additional rights are indicated by a Creative Commons license in the record and/ or on the work itself. This Dissertation has been accepted for inclusion in WVU Graduate Theses, Dissertations, and Problem Reports collection by an authorized administrator of The Research Repository @ WVU.

For more information, please contact researchrepository@mail.wvu.edu. 


\title{
"Political Beings: Sociopolitical Influence on Federal District Court Judges' Criminal Sentencing Behavior."
}

\author{
Scott Harris
}

\author{
Dissertation submitted \\ to the Eberly College of Arts and Sciences \\ at West Virginia University
}

In partial fulfillment of the requirements for the degree of

Doctor of Philosophy in

Political Science

John Kilwein, Ph.D., Chair

Erin Cassese, Ph.D.

Corey Colyer, Ph.D.

Robert Duval, Ph.D.

Shauna Fisher, Ph.D.

Department of Political Science

Morgantown, West Virginia

2016

Keywords: Judge, Judicial, Criminal, Sentencing, Federal, District Judge Copyright 2016 Scott Harris 


\section{ABSTRACT}

\section{"Political Beings: Sociopolitical Influence on Federal District Court Judges' Criminal Sentencing Behavior."}

\section{Scott Harris}

Judicial scholars have long debated what factors influence judges' decisionmaking. Several competing theories have offered relatively parsimonious explanations for the motivations of appellate judges, but sources of influence for trial judges are relatively understudied. One area ripe for testing potential determinants of trial court behavior is the criminal sentencing behavior of federal district court judges. Recent empirical research has examined federal district court sentencing, but this research has often focused solely on the effects of legal policy change and judges' personal partisanship. These efforts are informative but ignore other potentially important contextual determinants of sentencing behavior, such as sentiment in the legal/judicial community, sentiment among the public, and pertinent objective conditions, such as crime rates and incarceration rates. Using a variety of methods in three different research designs, each emphasizing the change in judicial behavior over time, I test the extent to which district judges' sentencing decisions are impacted by broader social and political concerns. Results from the dissertation are decidedly mixed, but they do suggest that contextual influences are clearly an important component of sentencing behavior for many district judges. Future research efforts should pay heed to the potential impact of contextual factors on trial judge decision-making and seek to identify conditions under which social or political characteristics are most likely to affect judges. 


\section{Table of Contents}

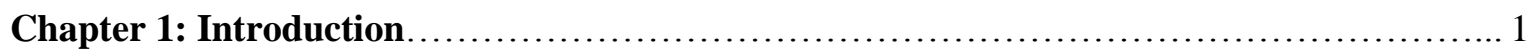

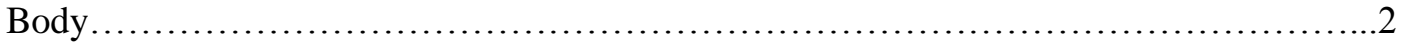

References................................................................. 22

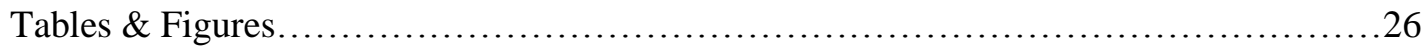

Chapter 2: "Not Like the Good Old Days: Judicial Departures From the US Sentencing Guidelines Over Time." ....................................... 27

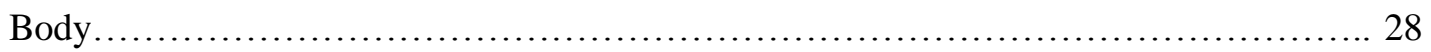

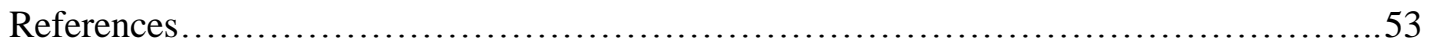

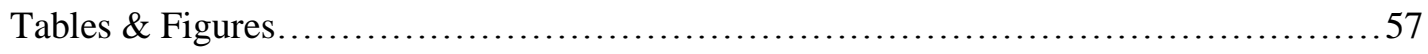

Chapter 3: "Of Time and Space: How Localized and Temporal Factors Influence Federal Judges' Criminal Sentencing Decisions." ......................61

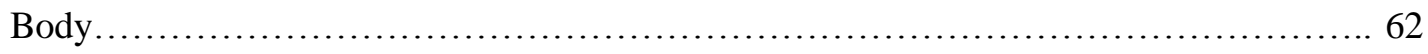

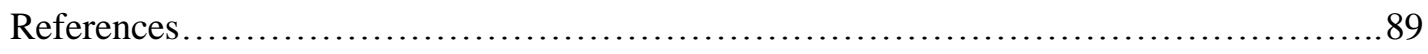

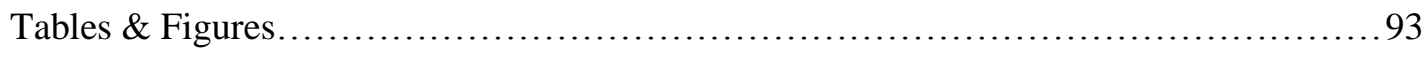

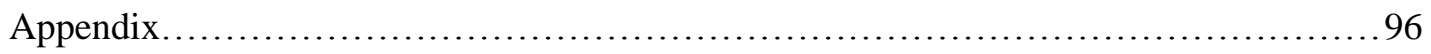

Chapter 4: "In Their Words: The Sentencing Decisions of Federal

District Court Judges According to Judges and Attorneys." ............................ 102

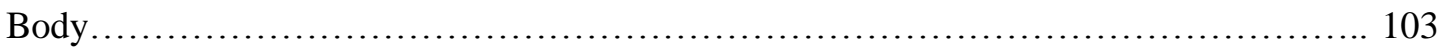

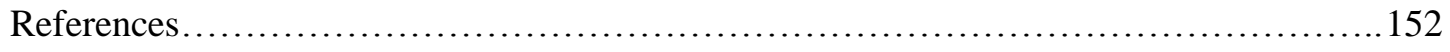

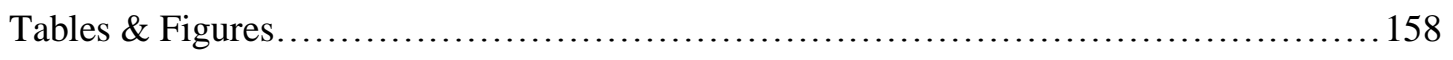

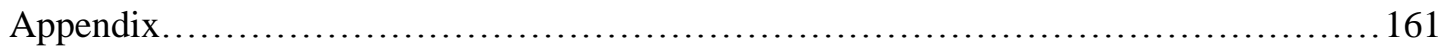

Chapter 5: Conclusion......................................................... 165

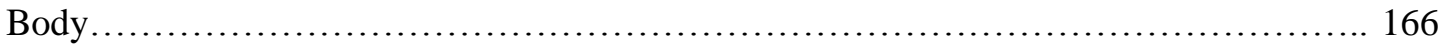

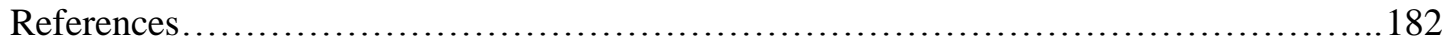




\section{Chapter 1: Introduction}

Under Article III of the United States Constitution, federal judges are appointed by the President of the United States and confirmed by the United States Senate. Once appointed, these judges hold their position for life, barring impeachment. One might suppose that given this type of job security, judges might be largely immune from political influence. Indeed, in Federalist 78, Alexander Hamilton justified life appointment for judicial officers by invoking the principle of a politically independent judiciary (Hamilton 2000). Hamilton argued that "the complete independence of the courts of justice is peculiarly essential in a limited Constitution" (2000, 497). The extent to which judges should ignore social and political considerations in a representative democracy is an important normative question identified at least as early as the Anti-Federalist response to Mr. Hamilton (Brutus 2003). Brutus argued that, while there should be some degree of judicial independence, in a republic, judges should ultimately be responsible to some body elected by the people.

From an empirical perspective, numerous scholars, inside and out of the legal field, have rigorously examined and questioned the extent to which Hamilton's principle of extreme federal judicial independence has been followed in practice (Woodford 2014; Carrington \& Cramton 2008; Ferejohn 2002; Spiller \& Gelly 1992; Kaufman 1978; Cook 1973, 1977). Other scholars have more narrowly focused on the extent to which public opinion impacts federal judges

(Casillas, et. al. 2011; Friedman 2009; Mishler \& Sheehan 1993; Franklin \& Kosaki 1989). However, with some notable exceptions (See e.g. Kim 2009; Rowland \& Carp 1996; Cook 1973, 1977), the vast majority of scholarship has focused on the appellate judges of the United States 
Supreme Court or the United States Court of Appeals. ${ }^{1}$ This asymmetry in research belies the fact that the majority of Article III judges are in fact trial judges, called "federal district court judges."

Every federal district court judge sits in one of ninety ${ }^{2}$ different districts throughout the United States. District court appointees are almost always long-time residents of the district to which they are appointed (Rowland \& Carp 1996; Silver \& Shapiro 1984). One duty of district court judges is to preside over criminal cases brought by the federal government against alleged violators of federal law. A particularly important aspect of this judicial task is to sentence criminal offenders once convicted. In the words of one former federal district court judge, "criminal sentencing is the most important duty of a [district court] judge."

Given the importance of the task of criminal sentencing, the relative dearth of scholarship on district judges, and the normative implications for the role of unelected judges, there is a necessity for further inquiry into the link between district judges' criminal sentencing behavior and politics. Accordingly, the central question of this study is as follows: are federal district court judges sensitive to social or political factors when sentencing convicted offenders?

The argument I develop in this dissertation is that district court judges' sentencing behavior is indeed influenced by these social and political factors to a greater degree than is appreciated in the extant research. ${ }^{4}$ It is important to note that my argument focuses on

\footnotetext{
${ }^{1}$ The federal judiciary is divided into three levels: ninety district courts, each underneath one of twelve court of appeal circuit courts, all underneath the Supreme Court of the United States. *excluding US territories.

${ }^{2}$ Excluding the U.S. territories of Puerto Rico, Guam, the US Virgin Islands, and the North Mariana Islands.

${ }^{3}$ Interview No. 12, January 21, 2016. See Chapter 4 for further details regarding these interviews.

${ }^{4}$ Throughout this dissertation, I use several different terms to describe these influences: "sociopolitical"; "contextual"; "environmental"; "exogenous", depending on the specific situation. Yet these terms can be thought of as interchangeable with respect to my broader theoretical perspective. Namely: district judges' decisions are shaped by the environment in which they operate.
} 
exogenous influences, such as public and elite opinion and the objective conditions pertinent to crime, rather than on district judges' party or ideology. This is not to suggest that district judges' political or personal preferences are irrelevant to their behavior, as they undoubtedly are. Instead, this research focuses on exogenous contextual factors in order to highlight the importance of context and demonstrate how much of district judge behavior is missed by simplifying it to a simplistic partisan or "left-right" dimension.

In this Introduction, I first provide background on the history and mechanics of federal sentencing policy and highlight the important role of district court judges in this arena. I then summarize competing theories of judicial behavior and explore how they fit with the present research. Next, I summarize recent empirical research on federal sentencing policy, and highlight some unresolved questions. I then develop a model of judicial behavior that serves as the theoretical underpinning of my argument for sociopolitical influence on district judge sentencing. Finally, I present a road-map of the dissertation by outlining the three chapters used to test my theoretical perspective.

\section{Background}

\section{The Importance of Sentencing Policy and the Role of Judges}

There are two reasons the present dissertation focuses on criminal sentencing, rather than other areas of the law. First, one of the most important aspects of judicial power is the power of the trial judge to sentence convicted criminals. The Sixth Amendment to the United States Constitution grants the power to determine the guilt or innocence of accused criminals to an impartial jury. However, dating back to British common law, the power to determine the punishment for criminals upon conviction has traditionally been left within the authority of judges (Mandiberg 2009). 
Beginning in the late 1980 's, the discretion afforded to district judges in sentencing decisions was reduced significantly. Legislators, police and other law enforcement, attorneys, probation officers, and other actors are all intimately involved in setting forth punitive policies (Stith \& Cabranes 1998). Furthermore, the past few decades have seen the growth of policies, such as mandatory minimum sentences and/or implementation of sentencing guidelines, seeking to restrict the sentencing authority of trial judges (USSC 2012). Even Attorney General Eric Holder has acknowledged the increased role of federal prosecutors in higher incarceration rates and has taken measures to curb mandatory minimum sentences for many nonviolent offenders (Holder 2010). ${ }^{5}$

Despite the multiple actors involved in sentencing policy, district court judges still have to make important sentencing decisions in the majority of individual cases. And while district judge sentencing discretion is no longer unfettered, the role of district court judges' individual preferences in determining sentencing outcomes has increased over the past decade (USSC 2012). Furthermore, as multiple studies have demonstrated the negative impact that mass incarceration has on society (Alexander 2012; Travis, et. al. 2006; Pattillo, et. al. 2004; Braman 2002; Freudenberg 2002), it is an extremely important societal question to ask how/why district judges arrive at these important sentencing decisions.

Aside from the theoretical appeal of a study of federal criminal sentencing, there is also a practical matter that renders research on the subject pertinent and timely. The United States Sentencing Commission (“Sentencing Commission”) has developed and recorded a wealth of

\footnotetext{
5 A substantial minority of federal offenders are convicted of offenses that carry these "mandatory minimum" penalties. In these cases, district judges have no discretion to unilaterally sentence criminals to shorter sentences than the proscribed statutory period. These "mandatory minimum" sentences have understandably garnered much attention from criminal justice reform advocates. However, it is important to realize that these cases still make up only 20-30\% of all federal criminal cases, depending on the year (USSC 2011). In the remainder of cases, as will be discussed in greater detail below, district judges have broader authority to arrive at their preferred sentence.
} 
data, documenting and coding every case of a federal criminal sentence, reported by the various district courts. This objectively-coded data provides extraordinary opportunities for both understanding relevant factors relevant to sentencing and for testing competing theories of judicial behavior.

None of the foregoing is meant to suggest that criminal sentencing is the only important aspect of a federal district court judge's role. Nor do I suggest criminal sentencing is necessarily akin to other judicial tasks. However, given the above considerations, criminal sentencing is an important and feasible policy area to test the theory of exogenous influences on judicial behavior.

\section{Sentencing Policy in US District Courts}

In order to understand the role of the district judges on criminal sentencing, some history and background on the mechanics of federal criminal sentencing is also required. Prior to the late 1980's, federal district court judges enjoyed relatively broad discretion in determining the sentences of convicted criminals (Stith and Cabranes 1998). Upon conviction, either by jury verdict or by plea agreement, judges were charged with the task of sentencing criminals within relatively wide statutory penalty ranges. Two early-to-mid twentieth century United States Supreme Court cases ${ }^{6}$ explicitly recognized this important distinction between determinations of guilt and determinations of punishment and further expounded that trial judges should be granted wide discretion in the latter area.

The era of discretionary sentencing in the federal court system would not last through the final two decades of the century. The passage of the 1984 Sentencing Reform Act (SRA) fundamentally altered sentencing in the federal courts. Specifically, among other provisions, the SRA provided for the creation of the Sentencing Commission to promulgate guidelines for

\footnotetext{
${ }^{6}$ U.S. v. Williams, 337 U.S. 241 (1949); Burns v. U.S., 287 U.S. 216 (1932).
} 
federal district court judges to follow in issuing sentences for those convicted of federal crimes. ${ }^{7}$ As a result, the Sentencing Commission was created as an independent agency of the judicial branch, with its members appointed by the President and approved by the Senate. Following its creation, the Commission promulgated the United States Sentencing Guidelines ("Guidelines"), which were placed into effect on November 1 1987. The Guidelines set forth relatively tight ranges of sentences for criminal defendants based on the type of offense committed and the offenders' criminal history.

One primary motivation behind the SRA was to reduce disparity in federal sentencing outcomes (Tiede 2009). In other words, the SRA sought to alleviate the problem of persons being convicted of similar or identical crimes in similar circumstances being sentenced to different punishments by different federal judges across the country. Whether and to what extent the implementation of the Guidelines has achieved this goal of reduced disparity is subject to some debate, although the weight of the evidence seems to suggest that inter-judge sentencing disparity has indeed decreased under the Guidelines (See Waldfogel 1991; Payne 1997; Hofer, et. al. 1999; Anderson, et. al. 1999; Tiede 2009). Regardless of the Guidelines' effect on sentencing disparity, it is undisputed that the Guidelines reduced trial judges' sentencing discretion from the pre-Guideline era (USSC 2012).

Still, despite policymakers' initial intentions, uniform sentencing through strict application of the Guidelines has also decreased markedly over time. The proportion of offenders sentenced below the Guideline recommended range has more than tripled from $14.8 \%$ in 1988 to $51.8 \%$ in 2014 (USSC 1995-2014). Crucially, this trend began well before 2005 when the Supreme Court ruled that application of the Sentencing Guidelines was merely "advisory" rather than mandatory (US v. Booker, 543 U.S. 220, (2005)). In fact, as will be discussed at

\footnotetext{
${ }^{7} 18$ U.S.C. $\S \S 351-386$.
} 
length throughout this dissertation, this trend of an increasing percentage of below-Guideline sentences has continued since Booker was decided in 2005 (USSC 1995-2014). But if formal changes in judicial policy with respect to the application of the Guidelines cannot fully explain the above-noted trend, are there other explanations? More fundamentally, what factors determine federal district court judicial sentencing behavior over time?

A primary objective of this research is to provide a more comprehensive explanation of federal district court sentencing behavior than is offered by the current literature. A secondary objective is to improve understanding of judicial behavior more generally. While the focus of the dissertation is on sentencing policy in federal courts, it is possible that significant determinants can be expanded to test other areas of law and/or aspects of judicial behavior.

\section{Judicial Behavior and Sentencing Policy: A Brief Overview}

\section{General Theories of Judicial Behavior}

Scholars of judicial behavior have emphasized a variety of different motivations affecting judicial decisions. In general, these scholars can be divided into four major schools: legal, attitudinal, strategic, and audience-based. While a comprehensive summary of each of these models is outside the scope of this work, a brief overview is necessary to emphasize the major positions and disagreements regarding what motivates judges and how many of these accounts may be unable to fully explain district judge sentencing behavior.

The traditional legal model essentially states that the judge's role is to use case-facts and apply those facts to the law, which can be discovered through both reason and application of precedent (Weinrib 1988). The attitudinal model proposed by Segal and Spaeth (2002) argues that the legal model does not conform to empirical reality and that the decisions of judges, especially Supreme Court justices, are driven almost entirely by their ideology. The strategic 
model espoused by Epstein \& Knight (1997) posits that justices do not simply vote their preference, but instead adjust their preferences based on the anticipated actions of other actors to arrive at the ultimate position closest to their preferences. Finally, Baum (2006) argues that the strategic and attitudinal models explain a great deal of judicial behavior, but they fail to account for the fact that judges are not perfect utility-seeking robots and have personal audiences whom they seek to please, such as other judges and the legal community.

While each of these models, excepting Baum's (2006), serve as an extremely parsimonious account of judicial behavior, they are generally tested by analyzing Supreme Court or other appellate court decisions. The attitudinal model, for example, has been extremely successful in predicting Supreme Court votes (Segal \& Spaeth 2002). Yet given their direct exposure to case-facts, along with their distinct hierarchy of goals, it is extremely likely that trial judges are less motivated by ideological and strategic considerations than appellate judges (Kim 2009; Baum 1997; Ashenfelter, et. al. 1995; Church, et. al. 1978). Indeed, several examinations of federal district courts have shown the importance of a variety of other factors outside the scope of the attitudinal/strategic models (See e.g. Zorn \& Bowie 2010; Swenson 2004; Sisk, et. al. 1998; Rowland \& Carp 1996; Ashenfelter, et. al. 1995; Kritzer 1978; Peltason 1971; Vines 1964; But See Sisk \& Heise 2012).

For example, one such factor deemed influential on district judges is the local political culture. As stated by two prominent scholars of district judges,

"the sociological impact of the community, in combination with an appointment process that tends to ensure that judges are representative of the local political culture, causes us to believe district judges are (at least somewhat) representative of their respective communities"

Rowland \& Carp (1996, 74-75). 
There is long-standing support for the notion that federal district court judges are influenced by their communities as Peltason (1971) and Vines (1964) found that Southern district justices following Brown v. Board did not enforce de-segregation, because of the judges' concern over their standing in their southern, elite communities. The importance of these works to the present dissertation is that they provide evidence that dominant appellate models of judicial behavior, such as the attitudinal model, offer an incomplete understanding of trial judge behavior. Baum's (2006) audience based framework is potentially more helpful, yet he offers no empirical test of this model, especially at lower-level courts.

\section{Specific Research on Federal Sentencing Behavior}

Moving beyond general studies of judicial behavior, there has also been a substantial amount of research done specifically on federal district court criminal sentencing. Historically, scholars conducting research in the pre-Guideline era of federal sentencing policy sought to determine whether political factors, both local and national, would affect the sentences of "draftdodgers" in federal courts. Specifically, Cook (1973) and Kritzer (1978) both analyzed the extent to which local and national opinion about the Vietnam War affected judges' sentences for convicted "draft dodgers."

Cook $(1973,1977)$ found the local political environment (both elite local opinion and public local opinion) influenced the sentences handed down to the "draft dodgers" by federal judges. Kritzer (1978) conducted a similar test that sought to improve on the explanatory power of Cook's model. Importantly, Kritzer found variables related to the political environment (both local and national) were the most important factors in explaining the sentencing decisions of federal district court judges, as opposed to judge-based characteristics or case-specific facts. Several more recent empirical efforts have been aimed at modeling judicial discretion under the 
Guidelines. Indeed, these recent empirical efforts have conducted studies directly related to the determinants of judicial sentencing and what factors influence departure from the Guidelines (Lynch and Omori 2014; Epstein, et. al. 2013; Fischman and Schanzenbach 2011; Tiede 2009; Wu and Spohn 2010; Schanzenbach \& Tiller 2007).

These research efforts have identified several factors that may affect district judge sentencing behavior. These factors include: levels of discretion (Epstein, et. al. 2012; Fischman \& Schanzenbach 2011; Freeborn \& Hartmann 2010); the partisan composition of district judges in particular judicial districts (Fischman \& Schanzenbach 2011); the partisan composition of circuit judges in the appellate court of appeals above the applicable district court (Epstein, et. al. 2013; Fischman and Schanzenbach 2011; Schanzenbach \& Tiller 2007); and the prevalence of mandatory minimum prosecutions within districts (Lynch and Omori 2014). Other recent research has attempted to explain inter-district variation in sentencing, but has focused broadly on ultimate outcomes, rather than on determinants of district judges' behavior (Wu and Spohn 2010; Tiede 2009; Kautt 2002).

\section{The Missing Link? Contextual Conditions}

The above referenced studies generally focus on two variables: partisanship and legalpolicy change affecting district judge discretion (Epstein, et. al. 2013; Fischman and Schanzenbach 2011). Stated in terms of the general models of judicial behavior, these works rely almost exclusively on strategic and attitudinal models of judicial behavior. Absent from these studies is an explanation for how different judges might alter their sentencing behavior in the face of changing conditions.

My argument with regards to district judge sentencing behavior is simple: context matters. District court judges are members of local communities. They live and work within 
specific geographic areas, and the relevant conditions in these communities pertinent to crime and punishment vary greatly both across the country and over time. As I will argue in more detail below, many district judges also care both about their reputations in these communities and the policy consequences of their sentencing decisions in these communities. Accordingly, given this premise, it is unlikely that most district judges ignore pertinent conditions in their community when making their sentencing decisions.

To add some specificity to this general argument, I posit that two types of contextual variables potentially influence sentencing decisions: objective conditions and societal punitiveness. Pertinent objective conditions include factors such as crime rates and incarceration rates. Societal punitiveness involves mass and elite opinion regarding crime and punishment. Intuitions aside, one might legitimately ask what evidence exists that suggests district judges are influenced by these contextual variables.

As to objective conditions, high crime rates could lead judges to pursue more punitive courses of action, as a means of incapacitating convicted criminals or deterring future criminals. There is some support for the crime rate hypothesis as Ulmer and Bradley (2006) found that Pennsylvania judges in counties with higher crime rates tended to render more punitive sentences. Gibson (1980) made a similar finding regarding Iowa judges. Gibson's findings are especially interesting, because Iowa state-judges travel across counties. Thus, Gibson finds that the same judges sentence criminals more severely in areas with higher crime rates. While there might be reasons to think that the Ulmer \& Bradley and Gibson results would not hold for unelected judges, their finding at least merits testing of whether the crime-rate impacts federal sentencing. 
Additionally, high incarceration rates resulting from the Guidelines (Stith and Cabranes 1998) might both signal to district judges that the Guidelines are not desirable or simply that the cost of implementing them is too great. There is scant past empirical work ${ }^{8}$ on the influence of incarceration rates on judges' sentencing behavior. However the notion that many judges care about good public policy independent of their partisanship (Baum 1997, 2006; Posner 2010) coupled with the facts that the skyrocketing federal incarceration rate observed since the implementation of the Guidelines has been mitigated by district judges in recent years (US DOJ 2015; USSC 2012; USSC 1995-2014) make it intuitively plausible that incarceration rates affect judicial application of the Guidelines.

As to societal punitiveness, there is substantial anecdotal evidence that judges care about elite opinion of themselves. Posner (1993) and Epstein, et. al. (2013) characterize reputation in the legal community as part of a judge's "utility function." Baum (2006) similarly argues many judges care about their ratings in law reviews and their standing among their judicial peers. Judges themselves have alluded to the influence of their peers on their behavior. As stated by one prominent federal judge, "we are impressed with each other, and strive to enhance the level of work of all of us." (Weinstein 1994, 555). Thus, to the extent the legal community and other elites have certain views regarding crime and criminal sentencing, we would expect district judges' sentencing decisions to be influenced by those views, in lieu of gaining a poor reputation.

Finally, there is also evidence that public opinion affects sentencing behavior. As noted above Kritzer (1978) and Cook (1973) both find that evidence that that lower levels of public support for the Vietnam War were associated with lower sentences for "draft-dodgers" by federal

\footnotetext{
${ }^{8}$ Although Ulmer and Johnson (2004) do find a positive relationship between jail capacity and odds of incarceration in Pennsylvania, which is a related, if not identical, argument
} 
district courts. There is additional support for public influence over sentencing decisions as Kuklinski and Stanga (1979) find that California state courts reduced their sentences in marijuana cases after California public opinion shifted in a liberal direction. Furthermore, Gibson (1980) interprets his crime-rate finding regarding Iowa judges as indirect support of the notion that public opinion influences judicial behavior, as he assumes that higher crime rates are associated with more punitive attitudes by the public.

To be fair, there are also certainly reasons to be skeptical that unelected judges would care deeply about public opinion. Evidence from state supreme courts suggests electoral calculations drive the effect of public opinion on judges' death penalty case decisions (Brace and Boyea, 2008). However, some studies have shown the sociological impact of a community shapes $^{9}$ federal district court judge behavior (Rowland \& Carp 1996; Kritzer, et. al. 1993). Furthermore, recent research on macro-politics implies that the public's punitive attitudes prompted both elected and unelected policymakers to incarcerate more individuals for longer periods (Enns 2014; Nicholson Crotty, et. al. 2009). Finally, given the specific findings of Kritzer (1978) and Cook (1973) that public and elite opinion factors affected federal district courts in criminal sentencing cases of draft-dodgers, the inclusion of public opinion variables to test the hypothesis more generally is certainly worthwhile.

\footnotetext{
${ }^{9}$ There is perhaps a more problematic issue with inferring a causal relationship between public opinion and judicial behavior. Epstein, et. al. (2013) and Segal \& Spaeth (2002) both note the difficulty of assuming that public opinion has a direct, causal effect simply because public opinion changes correspond with changes in judicial behavior. After all, judges are also members of the public, and they may simply be responding concomitantly to the same stimuli affecting the public at large. However, some recent scholars using temporal methods have argued that direct influence exists (Enns 2014; Mishler and Sheehan 1993). As I will discuss in greater detail throughout this dissertation, the debate over whether public influence is direct or indirect is important; but in my view, this inquiry is secondary to the more general question of whether judges concern themselves with exogenous contextual factors. Regardless of whether the influence of public or elite opinion is direct or indirect, it is most important to understand why the policy considerations of the public should matter to unelected judges who are, in theory, supposed to divorce themselves form extralegal considerations.
} 


\section{A Conceptual Framework of Judicial Behavior}

The main contribution of this work is not necessarily to develop a novel theory but instead to broaden understanding of trial-judge behavior and provide a more comprehensive empirical examination of district judge sentencing behavior. Still, the present dissertation has two general theoretical frameworks. First, I argue that district judges engaged in sentencing decisions are actors who are influenced by a multiplicity of influences (Rowland \& Carp 1996; Kritzer 1978). These influences lead judges to have an ideal preference for each sentence he/she gives. These ideal preferences are constrained by legal policy or other institutions, which influence, but cannot totally shape, the final sentencing decision (Kritzer 1978).

The causal diagram of my basic argument for judicial sentencing behavior is displayed in Figure 1 below.

\section{[Figure 1 about here]}

Figure 1 is a modified version of Kritzer's (1978) similar diagram of federal judges' decisions. Like Kritzer (1978), I posit that judges' sentencing decisions are complex and are ultimately the result of many different influences. Figure 1 is also consistent with the theoretical framework of Baum's $(1997,2006)$ audience-based perspective, which also emphasizes the multiplicity of influences on judges. Importantly, the model is very much a simplified typology ${ }^{10}$, as some categories surely overlap (Reputational Factors could be considered an aspect of Judge Characteristics). The model is categorized in this way simply, because it is a convenient heuristic for breaking down categories of potentially relevant variables that affect sentencing policy.

\footnotetext{
${ }^{10} \mathrm{I}$ also acknowledge the above model may not precisely replicate the process of how human beings make political decisions and that such decisions often involve a more complex two-step process (See Fiske and Taylor 1991; Conover and Feldman 1984). Instead, the model is simply intended as a simplification of how multiple influences may influence final sentencing decisions.
} 
As noted above, this model should not be necessarily viewed as a marked departure from prior understandings of district judge behavior. There seems to be scholarly consensus that no simplistic models would explain little of district judge behavior (See Rowland \& Carp 1996; Kritzer 1978). However, this more complex framework of multiple judicial influences has not been comprehensively tested in recent studies of district court criminal sentencing behavior (See Epstein, at. al 2013; Fischman and Schanzenbach, 2011; Freeborn and Hartmann, 2010).

In relation to Figure 1, these recent studies seem to assume that "Judge Characteristics" are the only factor that influences ideal sentencing behavior, and that legal policy changes then allow/restrict judges' ability to transfer that ideal point into their decisions. Yet, as discussed in greater detail above, there is both empirical and anecdotal evidence suggesting other contextual factors influence sentencing behavior of trial judges (Tiede 2009; Ulmer \& Bradley 2006; Kautt 2002; Gibson 1980; Kritzer 1978). Furthermore, there is evidence that the legal factors associated with the Guidelines cannot completely constrain judicial sentencing decisions (Lynch and Omori 2014). After all, there were still significant departures from the Sentencing Guidelines long before the Supreme Court ruled the Guidelines were not mandatory in 2005 (See USSC 1995-2014).

It is of course true, that environment and context have not been entirely ignored in studies of federal sentencing. Many scholars from the field of criminology have attempted to explain the causes of district variation in sentencing outcomes and have concluded that different district practices, especially those implemented in different U.S. attorneys' offices, can result in substantial variation in sentences for offenders (Lynch and Omori 2014; Wu and Spohn 2010; Ulmer 2005; Kautt 2002). However, as discussed in more detail in Chapters 3 and 4, there is still marked inter-district variation in how often judges choose to initiate departures from the 
Guidelines, independent of any differences in prosecutorial practices (USSC 1995-2014). This suggests that exogenous factors affect district judges' sentencing decisions, independent of any institutional differences amongst districts and their legal practices. Moreover, these studies focusing on regional variability in sentence-length tend to skirt theoretical question of why judges might behave differently in different districts. ${ }^{11}$ Accordingly, there is still a deficiency in understanding why district judges behave differently in different social and political contexts.

In summary, my general theoretical perspective, like Baum’s (2006) audience based perspective, emphasizes complexity and sacrifices parsimony for explanatory power. This tradeoff should not be taken lightly as parsimony is surely a valuable trait for any research endeavor. However, the dominant parsimonious models tend to leave unexplained variance in district judge behavior (Zorn \& Bowie 2010; Ashenfelter, et. al. 1995). If the inclusion of these additional factors identified in the bottom two boxes of Figure 1 can substantially improve our understanding of judicial behavior, this more complex model is a worthwhile endeavor.

In addition to the importance of studying multiple inputs, another theme present throughout this work is that district judge sentencing behavior is best studied over time. Because of low turnover in the federal judiciary, the difficulties in determining causal ordering in crosssectional work, and the substantial variation in sentencing behavior observed over time, this project is particularly suited for longitudinal analysis. While recent empirical works assuredly take into account trends in sentencing behavior, too often general trends are conflated with onetime changes to legal policy. In other words, these authors often assume that one time changes legal policy have lasting effects years after their adoption, irrespective of broader trends (Epstein, et. al. 2013; Fischman \& Schanzenbach 2011; Freeborn \& Hartman 2010).

\footnotetext{
${ }^{11}$ See Note 8, above.
} 
I argue that this assumption is simply not proper. The trend in increased departures from the Guidelines began well before Booker, or other legal policy changes, occurred (USSC 19952014). Furthermore, the trend continued after Booker and can be observed in the most recent 2014 data (USSC 1995-2014). It is simply not reasonable to assume that these trends are solely the product of legal policy change that occurred in 2005. My expectation is that the contextual variables identified above will help explain the more general trend and provide a better understanding of how district judges altered their sentencing behavior over time.

\section{A Road-Map of the Work}

The present work aims to improve on the past literature by incorporating previously untested variables and studying district court sentencing behavior at different levels of analysis. Each chapter also employs different methods. These different approaches are useful as both a robustness check of any potential findings as well as for explaining the potentially conditional nature of some explanatory variables. The common themes throughout all three empirical chapters are the importance of different social and political conditions and the change in district judge sentencing behavior over time.

\section{Chapter 2: The National Level}

Chapter 2 is a time-series analysis of trends in national-level sentencing. The primary contribution of Chapter 2 is to determine whether nationwide changes in: the partisanship of the judiciary; public punitive preferences; crime rates; and incarceration rates explain trends in the sentencing behavior of federal judges. More generally, this chapter seeks to probe different causes of judicial behavior by comparing and analyzing multiple time series, each linked in some way to different theories of judicial behavior. 
One might query why a theory focused on contextual influence would model the aggregate sentencing decisions of all district judges throughout the country. One answer to this query is that the nationwide analysis of this chapter is focused on the effect that "time" has on sentencing decisions rather than "place". Yet the national level time-series design allows no room for variation among different judicial districts nor for variation among different judges. Obviously, such a model is overly simplistic, as we know from past studies that different types of judges in different parts of the country behave differently (Tiede 2009; Wu and Spohn 2010; Kautt 2002; Rowland and Carp 1996). Furthermore, the nationwide data is unable to tap into potentially relevant considerations for judges who must make sentencing decisions, such as regional/local reputational factors.

However, there are certain distinct advantages for including a nationwide model of sentencing decisions. First, a macro-analysis allows for potentially more parsimonious explanations of district judges' sentencing behavior. While the theoretical framework of the present work generally trades parsimony for explanatory power, this chapter potentially allows for results that carry less conditions and caveats than region-specific levels of analysis. In addition, the nationwide analysis allows for comparisons of whether district judges respond to national trends or localized trends. While my conception of district judges would expect stronger local influence, the conclusion chapter will discuss how the results from Chapter 2 suggest some district judges might respond to different constituencies.

\section{Chapter 3: The District Level}

Chapter 3 employs a panel design, by examining annual Guideline Departure rates in every federal district court from 1996-2011. Several of the same variables employed in Chapter 2 are used in Chapter 3, but they are measured at state (or when possible district) levels. The 
major contribution of Chapter 3 is that it improves on past designs related to Guideline departures by including additional community-level variables that potentially impact district judges' sentencing behavior over time. As set forth above, many of these variables have been postulated in past theoretical work, but empirical testing has been limited.

Moreover, Chapter 3 allows for the inclusion of localized/geographic concerns that were ignored in Chapter 2. As argued above, and as noted by other scholars (Rowland and Carp 1996; Kritzer, et. al. 1993), district judges identify with other members of both their social and geographic communities. Thus, it would be surprising to find that judges are not sensitive to the concerns of these communities.

Third, although one focus of the second empirical chapter is intra-district change over time, separate "random effects" models also analyze differences between districts. Different districts throughout the country have different crime types. Thus, judges in different districts deal with different types of cases and offenders, so comparisons between districts should be used with some caution. Still, certain models in Chapter 2 attempt to account for these differences and parse out why/how certain judges in certain districts apply the Guidelines differently.

\section{Chapter 4: Qualitative Analysis of Four Districts}

The final empirical chapter of the present work is a more in-depth study of sentencing practice within four selected federal districts. The primary purpose of this chapter is to assess whether the suggested explanatory variables from the models in Chapters 1 and 2 are supported by a more in-depth investigation into the actual behavior of district court judges over the relevant time period. Unlike the two previous chapters, which are primarily quantitative, this chapter involves thick description and qualitative methods. 
In particular, Chapter 4 presents results obtained from interviews with federal district court judges, former federal district court judges, federal public defenders, United States attorneys, and private practice criminal defense attorneys experienced in federal sentencing. The interviews probe sources of influence on federal district court judges' sentencing determinations by discussing federal sentencing with both judges themselves and with attorneys who have experience observing, and potentially impacting, sentencing decisions.

This final interview-based empirical chapter adds significant value to the dissertation. In addition to the previously stated goal of providing potential corroboration for the quantitative studies, this interview-grounded chapter provides more detail and description of federal district court judges' sentencing decisions. This description is valuable by supplementing any facts gleaned in the prior two quantitative chapters with relevant interpretations of how and why those facts are influential on judges (Geertz 1973).

Yet another strength of using these qualitative interviews is they provide insight into the process by which district court judges changed their sentencing practices throughout the policy changes that occurred over the past two decades (See George and Bennet 2005; Tansey 2007). As discussed previously, there is no doubt that federal sentencing has changed dramatically in recent years. It is beneficial to understand how and why this change came about by soliciting perspectives from persons directly responsible for and/or observing this change.

Finally, the interview chapter is also beneficial for testing competing theories of district court behavior. Chapter 4 includes not only quotes and interpretations but also descriptive statistics and other qualitative methods used in hypothesis-testing. Though the use of these methods do not allow for strong causal statements, the results will still be beneficial for facial validity testing (See MacDonald 2007). In other words, it would be difficult to maintain any 
theory of district court judge sentencing behavior (attitudinal, contextual, etc.) if strong majorities of experienced federal sentencing actors, including judges themselves, are resoundingly dismissive of this theory. On the other hand, strong and broad support for a given theory by the interview subjects would further bolster that theory's case and provide impetus for further empirical testing.

\section{Chapter 5: Conclusion and Future Research}

After the third empirical chapter, I conclude the dissertation with a chapter summarizing the results. In this concluding chapter, I discuss in which ways my theoretical perspective of contextual/sociopolitical influence has been supported, and in which ways it has shown to be limited. I also discuss implications of this research and suggest areas for further study.

\section{A More Complete Picture of Judicial Behavior \& Federal Criminal Sentencing}

Criminal sentencing is one of the most socially important activities of the federal judiciary. The United States incarceration rate stands as a dramatic outlier to the rest of the democratic world (Walmsley 2013). This high rate of incarceration can, at least in part, be attributed to application of the US Sentencing Guidelines in the federal judiciary (Stith and Cabranes 1998). This dissertation will lead to a better understanding of why and how district judges choose to apply the Guidelines or ignore them. Understanding district judges' use and application of the Guidelines over time can also allow us to assess more accurately the factors that affect judicial decision-making, regarding the socially important act of incarceration.

This dissertation will also provide additional insight into judicial behavior generally. Using a variety of different methods and techniques, I test the extent to which district judges are influenced by contextual factors, personal factors, and legal constraints. The relative weight 
each of these variables has on judicial decision-making is fundamentally important to

understanding the role of an unelected federal judiciary in our democracy.

Finally, the dissertation also provides a more comprehensive examination of district judges' sentencing decisions. While past scholarship has examined the sentencing behavior of district judges under the Guidelines, I argue these approaches have been unduly limited in scope. In order to improve upon past research, this dissertation expands the scope of explanatory variables, uses multiple different methods, and accounts for longer-term trends in sentencing policy. Thus, irrespective of results as to specific sources of influence, the broader framework of this dissertation will improve understandings of both district judge behavior and federal criminal sentencing.

\section{References}

Alexander, Michelle. 2012. The New Jim Crow: Mass Incarceration in the Age of Colorblindness. New York: The New Press.

Ashenfelter, Orley, Theodore Eisenberg, and Stewart J. Schwab. 1995. "Politics and the judiciary: The influence of judicial background on case outcomes."The Journal of Legal Studies 24(2): 257-281.

Baum, Lawrence. 2006. Judges and Their Audiences. Princeton, NJ: Princeton University Press.

Baum, Lawrence. 1997. The Puzzle of Judicial Behavior. Ann Arbor, MI: University of Michigan Press.

Braman Donald. 2002. "Families and Incarceration.” In Invisible Punishment: The Collateral Consequences of Imprisonment. ed. M. Mauer and M. Chesney-Lind, New York: New Press.

"Brutus" 2003. The Anti-Federalist Papers and the Constitutional Convention Debates. ed. Ralph Ketcham. Penguin.

Carrington, Paul D., and Roger C. Cramton. 2008. "Judicial Independence in Excess: Reviving the Judicial Duty of the Supreme Court." Cornell Law Review 94: 587.

Casillas, Christopher J., Peter K. Enns, and Patrick C. Wohlfarth. 2011. "How Public Opinion Constrains the US Supreme Court." American Journal of Political Science 55(1): 74-88.

Church Jr, Thomas, Alan Carlson, Jo-Lynne Quong Lee, Teresa Tan, Kenneth Chantry, and Larry L. Sipes. 1978. "Justice delayed: The pace of litigation in urban trial courts." State Court Journal 2: 3-41.

Conover, Pamela \& Stanley Feldman. 1984. "How People Organize the Political World: A Schematic Model." American Journal of Political Science 28:95-126.

Cook, Beverly B. 1973. "Sentencing Behavior of Federal Judges: Draft Cases 1972." Cincinnati Law Review 42:597-633. 
Cook, Beverly B. 1977. "Public Opinion and Federal Judicial Policy." American Journal of Political Science 21: 567-600.

Enns, Peter. 2014. "The Public's Increasing Punitiveness and Its Influence on Mass Incarceration in the United States" The American Journal of Political Science. 58(4): 857-872.

Epstein, Lee \& Jack Knight. 2003. The Choices Justices Make. Washington, D.C.: CQ Press.

Epstein, Lee, William M. Landes, \& Richard A. Posner. 2013. The Behavior of Federal Judges. Cambridge, MA: Harvard University Press.

Ferejohn, John. 2002. "Judicializing Politics, Politicizing Law." Law and Contemporary Problems 65: 41-68.

Fischman, Joshua B. \& Max Schanzenbach. 2011 "Do Standards of Review Matter? The Case of Federal Criminal Sentencing." Journal of Legal Studies 40:405-437.

Friedman, Barry. 2009. The Will of the People: How Public Opinion Has Influenced The Supreme Court And Shaped the Meaning of the Constitution. London: Macmillan.

Fiske, Susan, \& Shelly Taylor. 1991. Social Cognition. 2d ed. New York: McGraw-Hill.

Franklin, Charles H., and Liane C. Kosaki. 1989. "Republican Schoolmaster: The US Supreme Court, Public Opinion, and Abortion." American Political Science Review 83: 751-771.

Freeborn, Beth A., and Monica E. Hartmann. 2010. "Judicial Discretion and Sentencing Behavior: Did the Feeney Amendment Rein In District Judges?" Journal of Empirical Legal Studies 7:355-378.

Freudenberg, Nicholas. 2002. "Adverse Effects of US Jail and Prison Policies on the Health and Well-Being of Women of Color.” American Journal of Public Health 92(12):1895.

Geertz, Clifford. 1973. The Interpretation of Cultures: Selected Essays. New York: Basic Books

George, Alexander L., \& Bennett, Andrew. 2005. Case Studies and Theory Development in the Social Sciences. Cambridge, MA: MIT Press.

Gibson, James L. 1980. "Environmental Constraints on the Behavior of Judges: A Representational Model of Judicial Decision Making. Law \& Society Review 14:343-370.

Hamilton, Alexander, John Jay, and James Madison. 2000. The Federalist. Edited by Robert Scigliano. New York: Modern Library.

Holder, Eric. 2010. "Memorandum from Eric H. Holder, Jr., Attorney General, to All Federal Prosecutors." Accessible at: http://www.justice.gov/oip/holder-memocharging-sentencing.pdf.

Johnson, Brian. 2003. Racial and Ethnic Disparities in Sentencing Departures Across Modes of Conviction. Criminology 41:449-88.

Kaufman, Irving R. 1979. "Chilling Judicial Independence." Yale Law Journal 88: 681-716.

Kautt, Paula M. 2002. "Location, Location, Location: Interdistrict and Intercircuit Variation in Sentencing Outcomes for Federal Drug-Trafficking Offenses." Justice Quarterly 19(4): 633-671.

Kim, Pauline T. 2009 "How Should We Study District Judge Decision-Making?" Washington University Journal of Law and Policy 29:83 
Kritzer, Herbert. 1978. "Political Correlates of the Behavior of Federal District Judges: A Best Case Analysis." Journal of Politics 40:25-58.

Kritzer, Herbert M., and Frances Kahn Zemans. 1993. "Local Legal Culture and the Control of Litigation." Law \& Society Review 27:535-558

Kuklinski, James H. and John E. Stanga. 1979. "Political Participation and Government Responsiveness: The Behavior of California Superior Courts." American Political Science Review 73:1090-1099.

Lynch, Mona and Marisa Omori. 2014. "Legal Change and Sentencing Norms in the Wake of Booker: The Impact of Time and Place on Drug Trafficking Cases in Federal Court." Law and Society Review 48 (2):411-445.

Macdonald, Jason A. 2007. “The US Congress and the Institutional Design of Agencies." Legislative Studies Quarterly 32(3): 395-420.

Mandiberg, Susan. 2009. "Why Sentencing by a Judge Satisfies the Right to Jury Trial: A Comparative Law Look at Blakeley and Booker." Mcgeorge Law Review 40: 107.

Mishler, William, and Reginald S. Sheehan. 1993. "The Supreme Court as a Countermajoritarian Institution? The Impact of Public Opinion on Supreme Court Decisions." American Political Science Review 87(1):87-101.

Nicholson-Crotty, Sean, David A.M. Peterson, and Mark D. Ramirez. 2009. "Dynamic Representation(s): Federal Criminal Justice Policy and an Alternative Dimension of Public Mood." Political Behavior 31(4):629-655.

Pattillo, Mary, Bruce Western, and David Weiman, eds. 2004. Imprisoning America: The Social Effects of Mass Incarceration: The Social Effects of Mass Incarceration. New York: Russell Sage Foundation.

Peltason, Jack AW. 1971. Fifty-Eight Lonely Men: Southern Federal Judges and School Desegregation. Urbana, IL: University of Illinois Press.

Posner, Richard A. 2010. How Judges Think. Harvard University Press.

Posner, Richard A. 1993. "What do Judges and Justices Maximize? (The Same Thing Everybody Else Does)." Supreme Court Economic Review 3:1-41.

Rowland, C.K. \& Robert A. Carp. 1996. Politics and Judgment in Federal District Courts. Lawrence, KS: University of Kansas Press.

Schanzenbach, Max M., and Emerson H. Tiller. 2007. "Strategic Judging under the U.S. Sentencing Guidelines: Positive Political Theory and Evidence." Journal of Law, Economics, and Organization 23:24-56.

Segal, Jefferey A. and Harold J. Spaeth. 2002. The Supreme Court and the Attitudinal Model Revisited. New York: Cambridge University Press.

Silver, Charles and Robert Shapiro. 1984. "Public Opinion and the Federal Judiciary: Crime, Punishment, and Demographic Constraints.” Population Research and Policy Review 3:255-280.

Sisk, Gregory C., and Michael Heise. 2012. "'Ideology' All the way down"? An Empirical Study of Establishment Clause Decisions in the Federal Courts." Michigan Law Review 110(7): 1201-1263.

Songer, Donald R. 1982. "Consensual and Nonconsensual Decisions in Unanimous Opinions of the United States Courts of Appeals." American Journal of Political Science 26:225-239.

Spiller, Pablo T., and Rafael Gely. 1992. "Congressional Control or Judicial Independence: The Determinants of US Supreme Court Labor-Relations Decisions 1949-1988." The RAND journal of Economics 23:463-492. 
Stith, Kate \& Jose A. Cabranes. 1998. Fear of Judging: Sentencing Guidelines in the Federal Courts. Chicago, Il: University of Chicago Press.

Swenson, Karen. 2004. "Federal District Court Judges and the Decision to Publish." Justice System Journal 25:121-142.

Tansey, Oisin. 2007. "Process Tracing and Elite Interviewing: A Case for Non-Probability Sampling." PS: Political Science \& Politics, 40(04):765-772.

Tiede, Lydia B. 2009. "The Impact of the Federal Sentencing Guidelines and Reform: A Comparative Analysis." Justice System Journal 30:34-49.

Travis J, Cincotta EM, Solomon AL. 2003. "Families Left Behind: The Hidden Costs of Incarceration and Reentry." Urban Inst. Policy Brief: Washington, DC.

Ulmer, Jeffery T. 2005. "The Localized Uses of Federal Sentencing Guidelines in Four U.S. District Courts: Evidence of Processual Order," Symbolic Interaction 28: 255.

Ulmer, Jeffery T. \& Mindy S. Bradley. 2006. "Variation in Trial Penalties Among Serious Violent Offenses." Criminology 44:631-670.

Ulmer, Jeffery T., \& Brian Johnson, B. 2004. Sentencing in Context: A Multilevel Analysis. Criminology 42: 137178.

United States Department of Justice. 2015. "Prisoners in 2014." Accessible at: http://www.bjs.gov/content/pub/pdf/p14.pdf

United States Sentencing Commission. 2012. Report on the Continuing Impact of United States v. Booker on Federal Sentencing. Washington, DC: US Sentencing Commission.

United States Sentencing Commission. 2011. Report to the Congress: Mandatory Minimum Penalties in the Federal Criminal Justice System. Washington, DC: US Sentencing Commission

United States Sentencing Commission. 1995-2014. Sourcebook of Federal Sentencing Statistics. Available at: http://www.ussc.gov/Research_and_Statistics/Annual_Reports_and_Sourcebooks/Archives.cfm

Vines, Kenneth. 1964. "Federal District Judges and Race Relations Cases in the South." Journal of Politics 26:337-357.

Wamsley, R. 2013. World Population List $10^{\text {th }}$ Ed. Essex: International Centre for Prison Studies.

Weinstein, Ian. 1998. "Substantial Assistance and Sentence Severity: Is There a Correlation Substantial Assistance." Federal Sentencing Reporter Rep 11: 83-85.

Weinrib. E. J. 1988. "Legal Formalism: On the Immanent Rationality of Law. Yale Law Journal 97:949-1016.

Woodford, Howard J. 2014. Courts of Appeals in the Federal Judicial System: A Study of the Second, Fifth, and District of Columbia Circuits. Princeton, NJ: Princeton University Press.

Wu, Jawjeong \& Cassia Spohn. 2010. Interdistrict Disparity in Sentencing in Three U.S. District Courts." Crime and Delinquency 56: 290-322.

Zorn, Christopher, and Jennifer Barnes Bowie. 2010. "Ideological Influences on Decision Making in the Federal Judicial Hierarchy: An Empirical Assessment.” Journal of Politics 72:1212-21. 


\section{Figure 1: Causal Diagram of the Determinants of Federal District Court Judges Sentencing Decisions}

\section{Judge Characteristics:}

-demographics, partisanship, ideology etc.

\section{Case Facts:}

-defendant characteristics, seriousness of the offense, etc.

Reputational Factors:

-opinion among: judicial community, legal community, general public

Objective Conditions:

policy evaluation, crime rates,

incarceration rates, recidivism rates,

etc.
Legal Constraints:

-Guideline

recommended range,

mandatory/advisory

nature of Guidelines,

standard of review for

appellate court

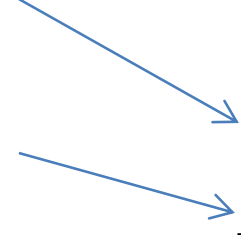

udge's Ideal Sentence

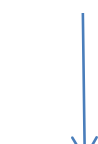

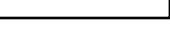

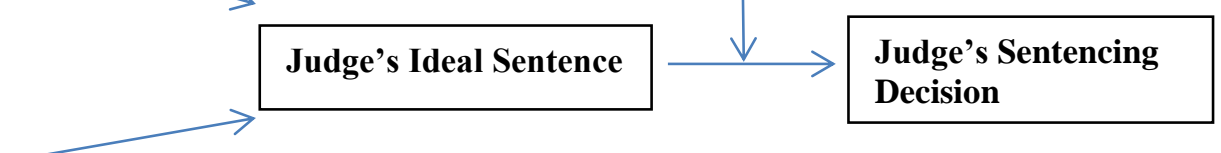




\title{
CHAPTER 2:
}

\section{"Not Like the Good Old Days: Judicial Departures From the US Sentencing Guidelines Over Time."}

\begin{abstract}
:
Recent scholars in sentencing policy have identified several factors that have affected federal district court judges' sentencing decisions under the U.S. Federal Sentencing Guidelines. While this research has advanced our understanding of both sentencing policy and judicial behavior, they have not fully explained the extreme change in judicial adherence to the Guidelines since they were implemented in 1987. The present chapter posits that district judges are attentive to both public views and the objective failures or successes of criminal justice policy. This article employs a time-series ARIMAx model to test the potential effects of three possible causes of judicial sentencing behavior consistent with this theoretical perspective: the punitive attitudes of the general public, the crime rate, and the incarceration rate. Results do not support the hypotheses that either higher crime rates or the punitive attitudes of the public are associated with judicial sentencing behavior. However, results offer limited support for the hypothesis that higher incarceration rates lead sentencing judges to mete out more lenient sentences. In total, while not strongly supportive of the present hypotheses, the findings do suggest that future research should utilize different methods and incorporate new variables to improve upon models of the sentencing behavior of district judges.
\end{abstract}




\section{Introduction}

An important open question in federal sentencing policy is what factors federal district court judges consider when making sentencing decisions under the United States Sentencing Guidelines (hereafter "the Guidelines")? To be sure, substantial research has been conducted on federal sentencing during the Guideline era (Epstein, et. al., 2013; Fischman and Schanzenbach, 2011; Tiede, 2009; Schanzenbach \& Tiller, 2007; Mustard, 2001). These studies have made important contributions and have provided evidence that district judges may be influenced by changes in judicial policy (Epstein, et. al., 2013; Fischman and Schanzenbach, 2011), partisan factors (Epstein, et. al., 2013; Fischman and Schanzenbach, 2011; Stidham and Carp 1988), and the demographics of the offender (USSC 2012; Mustard, 2001) when making sentencing decisions.

Despite these contributions, these pieces of research are limited in that they do not incorporate many potentially influential contextual and environmental variables into their studies. Scholars of judicial behavior have found that judges, especially at lower levels of the judiciary, respond to multiple inputs when making decisions and are generally representative of their communities (Sisk. et. al., 1998; Baum 1997; Rowland \& Carp, 1996; Kritzer 1978). Given these findings, pertinent sociopolitical factors such as public sentiment regarding crime, the crime rate, and the incarceration rate could all potentially influence judicial decision-making.

Another limitation of past federal sentencing research is its tests cannot fully account for the dramatic changes to district judge adherence to the Guidelines over time (USSC 1995-2014). As argued more thoroughly below, district judges no longer apply the Guidelines at rates remotely comparable to the rates when they were first implemented, and this trend cannot be solely attributed to the effect of legal changes on judges' discretion. Thus, regardless of the 
potential effects of the above mentioned exogenous variables, more comprehensive testing of district judge sentencing behavior over time is warranted.

In this chapter, I first provide some background information regarding federal sentencing. Next, I survey some past efforts at examining judicial sentencing under the Guidelines. Third, I explain some of the broader theories of judicial behavior and how they might fit in with the framework of district judge criminal sentencing. Fourth, I develop the argument that public attitudes and objective conditions are potentially important, but largely untested, factors influencing district judge sentencing behavior. Fifth, I execute the research design and provide the empirical results. Finally, I conclude with a discussion of the results and their implications.

\section{Background}

As discussed more thoroughly in Chapter 1, federal district court judges had a significant amount of discretion in sentencing federal criminal offenders prior to 1987. However, beginning on November 1, 1987 with the implementation of the Guidelines, district judges were forced to calculate a recommended sentence for each offender. Guideline recommended sentences are primarily based on two variables: 1) the seriousness of the offense (as quantitatively defined by the Sentencing Commission); and 2) the criminal history of the offender (passed upon a "points system"). Table 1, below, is an example of the Guidelines sentencing matrix from 2012.

\section{[Table 1 about here]}

As can be seen in Table 1, the vertical axis of the matrix ascribes each federal offense with a "level," and the horizontal axis of the matrix depends on how many "criminal history points" the offender has. As can also be gleaned from Table 1, application of the matrix results in relatively tight ranges of sentences, measured in units of monthly imprisonment (e.g. 21-27 months). Although there are procedures within the Guidelines framework that allow for 
adjustments to sentences in a limited number of circumstances, most sentences are calculated using solely these two deterministic quantitative variables. In fact, federal probation officers, rather than district judges, are responsible for calculating the Guideline sentence for each offender. (Stith and Cabranes 1998). Given the fact district judges enjoyed relatively uninhibited judicial discretion in sentencing prior to the Guidelines' adoption, an important question to ask is how district judges responded to this dramatic change?

The raw data presents a somewhat complex and era-dependent answer to this question. When the Guidelines first took effect in fiscal year ${ }^{12}$ (hereafter "FY") 1988, the percentage of sentences within the proscribed Guideline range was 82.3\% (USSC 1995-2014). By FY 2014, the percentage of within-Guideline sentences was only $46 \%$, and the vast majority of these deviant sentences outside the Guideline range (95.9\%) were below, rather than above, the Guideline recommended range (USCC 1995-2014). In other words, the Guidelines are not applied nearly as strictly as they used to be.

A well-studied explanation for this dramatic trend relates to changes in legal rules/policy pertinent to the Guidelines. Two such changes of import were portions of the 2003 PROTECT Act $^{13}$ enacted by Congress and the 2005 Supreme Court case of US. v. Booker, 543 U.S. 220 (2005) (“Booker"). These two policy changes had opposing effects. The PROTECT Act constrained district judges' ability to depart from the Guidelines by allowing appellate courts to review sentencing decisions without deference to the original decision of the sentencing district judge. On the other hand, Booker augmented judicial discretion by holding that the Guideline ranges must be merely "advisory," rather than mandatory. The Supreme Court further clarified

\footnotetext{
${ }^{12}$ The Federal Fiscal year runs from October 1 of the prior year to September 30 of the corresponding calendar year. Thus, for example, FY 2014 includes all cases from October 1, 2013-September 30, 2014.

${ }^{13}$ Pub. L. No. 108-121, 117 Stat. 650
} 
in Booker that district court judges could legally "depart" from the Guidelines' recommended range so long as the departure was "reasonable." However, as will be evidenced in more detail below, neither the PROTECT ACT nor Booker tell the complete story of Guideline adherence. Figure 1, below, provides graphical representation of the annual percentage of offenders receiving below-Guideline sentences since 1988 .

\section{[Figure 1 about here]}

As can be seen from Figure 1, the trend in increased below-Guideline sentence-ranges began well before the PROTECT Act was passed $2003^{14}$, and said trend has continued after Booker was decided through FY 2014 (USCC 1995-2014). Thus, it does not appear as if these policy changes are solely responsible for the increasing trend of below-Guideline sentences.

To be sure, part of the explanation for the clear trend can be attributed to factors outside the purview of judges. The Sentencing Commission has noted that increased government recommendations for below-guideline sentences helps explain the increased departure rate (USSC 2012). However, the Sentencing Commission has also acknowledged these extra-judicial factors do not tell the whole story and have noted that non-government sponsored downward departures have increased in recent years (USSC 2012). Furthermore, rates of below-Guideline sentences have increased across all major offenses, including the three most common nonimmigration federal offenses: drug trafficking, unlawful firearms possession/use, and fraud (USSC 1995-2014). Thus, there remain unanswered questions about why district judges are increasingly less apt to apply Guideline-recommended sentences to offenders. The fundamental question of this chapter is what other factors might be responsible for this trend?

\footnotetext{
${ }^{14}$ Although this trend did stall and reverse course after the passage of the PROTECT ACT in 2003.
} 


\section{Past Federal Judge Sentencing Research}

Social science research on how federal judges sentence criminals began at least forty years ago. Cook $(1973,1977)$ and Kritzer $(1978)$ both sought to examine what factors influenced federal judges sentencing "draft dodgers" of the Vietnam War. One key finding from both scholars was that the local political environment influenced the sentences handed down to the draft dodgers by federal judges (Cook 1973, 1977; Kritzer 1978). In other words, district judges did not appear to be making their decisions independently of the local and elite sentiment in the community towards the Vietnam War, which changed drastically over the course of the 1960's. Of particular importance, Kritzer found that the political environment factors were most important in explaining the sentencing decisions of district judges, when compared to characteristics of judges or case-specific facts.

Building upon the findings of Cook $(1973,1977)$ and Kritzer (1978), Silver and Shapiro (1984) conducted a more thorough test of the "representational model" of judicial behavior, which posits that judges' behavior reflects public sentiment. Applying this model to the district judges' role in sentencing, Silver and Shapiro found that federal judges were less likely to sentence criminals to probation, as popular sentiment for harsher penalties rose. Silver and Shapiro similarly found that increasing levels of public support for marijuana decriminalization and legalization were correlated with shorter sentences. However, Silver and Shapiro also found that judges were actually more likely to imprison offenders as opposed to probation, even as public support for legalization increased. Ultimately, Silver and Shapiro interpreted their mixed results as grounds for reappraising the representational model and posited that factors such as crime rates, incarceration rates, and issue salience should be included in examining the public opinion/sentencing connection. 
Despite the future research avenues laid out by Silver and Shapiro (1984), little recent federal sentencing scholarship has subjected the representational model to further testing. ${ }^{15}$ Instead, the recent scholarship on district judge behavior under the Guidelines has primarily focused on whether judges' partisan preferences or changes in judicial-discretion policy (e.g. pre- or post-Booker) have affected district judge's adherence to the Guidelines. Specifically, Fischman and Schanzenbach (2011) find that the 2003 PROTECT Act provisions which allowed appellate courts to review district court judge departures from the Guidelines without giving any deference to the district court judge, increased district court adherence to the Guidelines.

Fischman and Schanzenbach also find that the Booker decision, which invalidated this portion of the PROTECT Act and further rendered the Guidelines "advisory," resulted in decreased district judge adherence to the Guidelines. Similarly, in a recent study, Epstein, et. al. (2013) found that the rate of departures from the Guidelines has increased substantially in the post-Booker era. Both Fischman and Schanzenbach (2011) and Epstein, et. al. (2013) also detected strategic and partisan influences on sentencing behavior. In particular, both found that higher proportions of Republican circuit judges on the Court of Appeals sitting above the sentencing district court were associated with lower probabilities of Guideline departures by district judges.

This finding perhaps suggests that district judges are somewhat strategic when making sentencing decision and consider the odds their sentence will be overturned on appeal when making sentencing decisions. On the other hand, the finding could simply be reflective of the

\footnotetext{
${ }^{15}$ To be fair, one likely reason that recent research on judicial sentencing has not tested the "representational model" as thoroughly as older studies is simply that the representational model has not held up very well when subjected to empirical testing in other contexts. In their study of Supreme Court justice behavior, Segal and Spaeth (2002), find virtually no support for the notion that popular opinion influences justice decision-making. Even scholars propounding the notion that public opinion is relevant to Supreme Court decision-making are extremely cautious and conditional regarding their conclusions (Mishler and Sheehan 1993). On the other hand, other scholars find a strong connection between public influence and trial judge behavior (Kuklinski and Stanga 1979; Gibson 1980). Moreover, some recent research has promisingly examined the effect of public attitudes on sentencing policy in particular, and found evidence that sentencing outcomes (certainly not solely attributable to judges) are responsive to the public's punitive attitudes (Enns, 2014; Nicholson-Crotty, et. al., 2009)
} 
ideological composition of circuits and district courts. Past research finds a relationship between the liberalness of circuit judges and the liberalness of their home-state Senators (Songer 1982). In addition, there is evidence that, unlike district judges, circuit judges retire strategically by waiting for a President to be elected who more closely resembles their ideological perspective so that a similar policy-minded jurist will replace them (Spriggs \& Wahlbeck 1995). This research suggests that perhaps the observed relationship between circuit judge ideology/partisanship and district judge departure rates (Epstein, et. al. 2013; Fischman \& Schanzenbach 2011) is actually the result of relatively liberal areas of the country preferring less punitive policies. This interpretation is more aligned with the representational model of judicial behavior, as discussed above, as opposed to any sort of strategic behavior by district judges seeking to avoid reversal on appeal.

Aside from attitudinal effects, other researches have emphasized demographics of offenders as a key component to understanding why/how judges arrive at their sentences (Mustard 2001; USSC 2010). In a study of over 70,000 offenders since the implementation of the Guidelines, Mustard (2001) finds that African-Americans, males, and offenders with lower socio-economic status are generally sentenced more severely under the Guidelines. The Sentencing Commission has reached similar conclusions based on analyses of the average and median sentences for all demographic groups (USSC 2010). Several analyses have also addressed the degree to which increases in judicial discretion post-Booker exacerbated or mitigated racial biases in sentencing. While the Sentencing Commission finds that the increased discretion given to district judges has resulted in increased biases and undue sentencing disparity (USSC 2012), several studies have questioned this finding and argue that increased unwarranted 
disparities post-Booker are mostly due to prosecutorial behavior (Lynch \& Omori 2014; Rehavi \& Starr 2012).

\section{Reviving the Past: The Representational Model applied to the Post-Guideline Sentencing Era.}

The literature discussed above has advanced our understanding of how offender demographics, legal policies, and partisanship affect district judges' sentencing behavior in the post-Guideline era. However, most of this recent scholarship tests relatively narrow questions, and with the exception of studies on the effect of judges' partisanship, little attention is paid to larger theories about how district judges arrive at their sentencing decisions. Furthermore, none of these studies seem to offer nuanced explanations for why below-Guideline sentences continually increased after the Booker decision.

Perhaps the lack of attention to alternative influences on district judge decisions is a byproduct of the success of more parsimonious theories of appellate judicial behavior. ${ }^{16}$ The most prominent of these theories are likely the attitudinal theory holding that justices/judges are motivated by their personal ideology (Segal and Spaeth 2002), and the strategic theory holding that justices don't purely follow preferences but adjust their decisions based on the actions or likely actions of other actors to arrive at the optimal outcome (Epstein \& Knight 1998). Both of these theories are incorporated into recent studies on district judge sentencing, at least to the extent judges' partisanship (as deduced by the party of the President appointing them) is reflective of their ideology (Epstein, et. al. 2013; Fischman and Schanzenbach 2011). ${ }^{17}$

\footnotetext{
${ }^{16}$ See Chapter 1 for a more comprehensive explanation of trial judge/appellate judge differences.

${ }^{17}$ Needless to say this assumption may not hold, and some scholars of judicial behavior prefer "common space score" measures of judicial ideology, which incorporates measures of ideology from both the appointing presidents and the judges' home-state senators as an alternative to simple partisanship (See Giles, et. al. 2001).
} 
Yet there is some evidence that the attitudinal and strategic models do not have the same explanatory value when applied to district judges. Rowland and Carp (1996), perhaps the leading authorities on federal district court judges, argue these judges are often influenced by a multiplicity of influences that do not fit squarely within parsimonious attitudinal models. Similarly, Kritzer (1978) posits that several factors, including judge characteristics, case facts, and legal constraints, affect how district court judges make decisions. ${ }^{18}$ Baum (2006) claims that judges of all kinds take into account their audiences when making decisions and that the attitudinal and strategic models portrait of judges as "single-minded utility seekers" is overly simplistic.

In addition, several scholars have noted that district court judges' are generally representative of their communities (Rowland and Carp 1996; Kritzer \& Zemans 1993; Peltason 1971; Vines 1964). It is an open question whether this representative nature of district judges applies to Guideline-era criminal sentencing, and if so, whether the relationship is causal or simply the result of judges being members of these communities (See Kritzer 1978; Cook 1973, 1977). However, some recent evidence suggests there is a causal relationship between public attitudes on crime and punishment and criminal justice policy outputs (Nicholson-Crotty, et. al. 2009; Enns 2014).

Finally, in addition to any representational factors, certain judicial behavior scholars maintain that some judges care about making the "right" decision and making "good public policy," independent of partisanship or ideology (Baum 1997; Posner 1993). In relation to criminal justice policy, district judges' conception of "good public policy” could potentially be influenced by sociopolitical conditions such as crime rates and incarceration rates. Scholars of

\footnotetext{
${ }^{18}$ See Chapter 1, Figure 1 for a diagram of my own theoretical perspective on district judge decision-making, which is similar in many respects to Kritzer (1978).
} 
state judges have indeed found that higher crime rates are correlated with judges meting out harsher sentences (Ulmer and Bradley 2006; Gibson 1980). There is also some evidence, however, that the crime rate bears little impact on district judges. ${ }^{19}$ It is perhaps possible that district judges are not as sensitive to crime-rate concerns because of the lack of an electoral connection. Elected state court judges may simply be issuing harsher sentences in higher crime areas in order to increase their electoral prospects with a public who desire tough-on-crime judges (Gibson 1980). Yet as discussed above, most scholarship on district judge behavior finds them susceptible to community influences, despite the lack of any electoral connection (Rowland and Carp 1996, Kritzer \& Zemans 1993; Peltason 1971; Vines 1964). Thus, it is worth further examining the relationship between crime rates and district judges' sentencing.

Incarceration rates also represent a plausible contextual factor district judges might consider in their sentencing decisions. While there is little research on the effect incarceration rates have on judges' sentencing habits, exploding incarceration within the federal system is a potential explanation for the trend observed in Figure 1. The logic of this theory is based upon the initial premise that district judges' preferences can change in the face of changing contexts. As more and more people were incarcerated in the post-Guideline era, especially for non-violent drug offenses, district judges may have viewed Guideline sentences as too punitive. As a result, I argue district judges began sentencing offenders to shorter sentences.

In summary, I aim to build upon recent studies on district judge sentencing practices (Epstein, et. al. 2013; Fischman and Schanzenbach 2011) by reviving tests of the representational model of judicial behavior examined by researchers in the 1970s and 1980s (Silver and Shapiro 1984; Kritzer 1978; Cook 1973). In addition, I choose to assess the impact relevant objective

\footnotetext{
${ }^{19}$ See Johnson, et. al. (2008) for a null finding of crime rate influence on district judges. The findings of Johnson, et. al. (2008) regarding the crime rate are discussed in more detail in Chapter 3.
} 
conditions, such crime rates and incarceration rates, might also have on district judges' sentencing decisions. It is quite plausible that an examination of these previously untested variables might explain the drastic change in district judge sentencing behavior that is depicted in Figure 1.

\section{Research Design}

\section{Hypotheses}

Consistent with my theory of contextual influences ${ }^{20}$ I posit three testable hypotheses. First, the "representational hypothesis" is: there will be a positive relationship between the public's punitive preferences and district judges' punitiveness in sentencing. Second, the "crime rate hypothesis" is: there will be a positive relationship between the crime rate and district judges' punitiveness in sentencing. Finally, the "incarceration rate hypothesis" is: there will be a negative relationship between the incarceration rate and district judges' punitiveness in sentencing.

\section{Dependent Variable}

\section{District Judge Punitiveness}

To measure the primary dependent variable of interest, district judge sentencing behavior, I use the proportions of offenders receiving two different types of below-Guideline sentences, also known as "departures," in fiscal years 1988 to $2013 .^{21}$ The first measure is the proportion of all offenders who receive any below-Guideline sentences ("Total Downward Departures"). The second measure is the same proportion, except that all offenders who receive below-Guideline

\footnotetext{
${ }^{20}$ For a more thorough discussion of the theoretical justification for these hypotheses, please see above and Chapter 1.

${ }^{21}$ Although data from Fiscal Year 2014 is available, this year was excluded from this analysis due to lack of data availability for certain exogenous covariates.
} 
sentences based upon providing "substantial assistance" to the government are excluded from the proportion (“Judge-Initiated Downward Departures").

The purpose of using two different departures measures is that some departures from the Guidelines are actually recommended and/or agreed to by the government or prosecution as part of a plea bargain. The majority ${ }^{22}$ of these government-sponsored departure cases throughout the series are these "substantial assistance" departures wherein the government makes a motion that the offender has provided substantial assistance in the investigation or prosecution of another person who has committed a crime (See Sentencing Guidelines Policy Statement 5K1.1). Essentially, these substantial assistance cases are cases where Guideline departures are recommended by the government because the offender provides law enforcement with information that allows them to resolve more serious cases. This distinction between total departures and substantial assistance departures sponsored by the government is possibly relevant, as there is some question as to whether Guideline departures recommended by the government should be included in an analysis of "judicial behavior."

On balance, I argue the Total Downward Departure measure is probably a more valid measure of district judge punitiveness. Even if recommended by the government, district judges still must approve below-Guideline sentences and are free to ignore the government's recommendation. Additionally, there is negative correlation between substantial assistance departure rates and non-substantial departure rates among different districts (Weinstein 1998; USSC 1995-2014), which suggests that district judges are not beholden to the government's

\footnotetext{
${ }^{22}$ Some government sponsored departures are not "substantial assistance" downward departures and include government-sponsored departure for other reasons. Unfortunately the Sentencing Commission did not begin coding all other "government sponsored departures" until 2003. Thus, the data does not allow for examination of only nongovernment sponsored departures for the full series. Still, given the "substantial assistance" departures are, by far, the most common government-sponsored departure, the measure of departures that excludes these cases should provide a fairly strong proxy for all non-government sponsored departures.
} 
recommendations. Moreover, other recent studies of district judge sentencing examine total departure rates, rather than any subset of departures (See e.g. Epstein, et. al. 2013). All of this evidence suggests that the Total Downward Departure measure is preferable. However, as a robustness check, and to ensure substantial assistance cases are not driving results, I also include the secondary measure of Judge-Initiated Downward Departures.

Setting aside the two alternative measures of departures, one might also question why the use of downward departure rates in general is an appropriate proxy for district judge punitiveness. ${ }^{23}$ The justification for using downward departure rates, as opposed to measures such as median length of sentence, is that laws, prosecutorial practices, and the Guidelines themselves change over time (USSC 2012). There also are changes to the types of cases prosecuted over time, as is evidenced by the increasing proportion of immigration offenders in recent years (USSC 1995-2014). Thus measuring Guideline downward departure rates more appropriately ${ }^{24}$ isolates the behavior of district judges than measuring mean or median sentence length.

In spite of the foregoing, two points merit discussion regarding the downward departure measures of judicial sentencing behavior. First, the measures do not include "upward departures" or occasions when the sentencing judge sentences the offender to a penalty that is more harsh that the penalty recommended by the Guidelines. The reasons for excluding upward departures from the analysis are both that upward departures are rare (an average of $1.6 \%$ of cases from FY 1988-2014) and they do not appear to exhibit coherent trends over time. Conversely, downward departures are fairly common (an average of $32.2 \%$ of all cases in from

\footnotetext{
${ }^{23}$ Note also that lower values of the departure measure imply more punitive behavior by district judges.

${ }^{24}$ Notably this measure of Guideline downward departures follows past research studying judicial sentencing behavior (Epstein, et. al., 2013; Fischman \& Schanzenbach 2011; Freeborn \& Hartmann 2010; Schanzenbach \& Tiller, 2007).
} 
FY 1988-2014) and exhibit relatively strong stability from one year to the next, with clear trends over the course of the series.

The second point regarding the downward departure measures is that they are not the only potential measures for whether district judges are treating criminals harshly. In addition to rates of Guideline departure, one alternative measure is the average Guideline minimum imprisonment sentence for all offenses in a given year compared to the average imprisonment sentence actually imposed in a given year (USSC 2012). The logic of this "average difference" measure is that if average sentences become relatively shorter/longer than average guideline minimums over time, then we have some evidence that judges are shifting to a less/more punitive direction. This alternative measure has the advantage of incorporating sentence length into the analysis and controlling for above-mentioned problems with average/median sentence length measures, such as changes to the Guidelines over time.

Despite these advantages, the "average difference" measure also has two key disadvantages. First, the average difference measure is susceptible to outliers. A few judges' decisions to give offenders the maximum Guideline-range, or above maximum Guideline-range sentence could greatly affect average difference. Overall departure rates present a more accurate overall picture of how punitive district judges' preferences are in a given year.

Second, the U.S. Sentencing Commission only has data on this measure beginning in 1996, rather than 1988, which eliminates nearly $30 \%$ of the observations. For these reasons, I opt for the downward departure measures. Still, the average difference measure may be appropriate in some contexts, and future tests and research should investigate whether this measure produces different results from the departure rate measure used in this design. 


\section{Input Variables}

\section{Policy Change}

Variables related to the two major policy changes in Guideline application that occurred will be incorporated through adjusted dummy variables. A " 1 " is coded for each fiscal year that the PROTECT Act was fully in effect, which limited judicial discretion, with a corresponding "0" for fiscal years when the PROTECT Act was not in effect. Similarly a " 1 " is coded for each year after $U S v$. Booker was decided, which expanded judicial discretion, and a "0" coded for years prior to the decision. As neither Booker nor the PROTECT Act were placed into, or taken out of, effect at the exact beginning or end of fiscal years, I calculate the proportion of cases in the year the policy was in effect for those fiscal years. ${ }^{25}$ For example, since U.S. v. Booker was in effect for approximately $76 \%$ of all cases with departure data in FY 2005, I code FY 2005 as a “0.76” for Booker.

\section{Public Sentiment Regarding Crime}

A new measure for public punitiveness has recently been developed by Enns (2014). The measure incorporates responses to 33 survey questions related to treatment of criminals and seeks to capture the general level of public punitiveness over time. ${ }^{26}$ For the years of 1988-2010, I simply use the gross measure utilized by Enns (2014). However, since the Enns (2014) measure is only constructed through 2010, I employ an estimated measure for public punitiveness, updated for the years of 2011 and 2012. Specifically, I utilize more recent data from survey questions to construct estimates of the same public punitiveness measure for the years of 2011 and 2012. To construct these estimates, I use survey questions that: 1) Enns

\footnotetext{
${ }^{25}$ As the Sentencing Commission does not have separate information for before and after the PROTECT Act was placed into effect, I instead use the proportion of the number of days that the PROTECT Act was in effect out of the entire fiscal year. This measure assumes that there is an even distribution of cases throughout the Fiscal Year.

${ }^{26}$ For a more detailed discussion of how the measure is constructed, see Enns (2014).
} 
himself incorporated into his measure in earlier years; 2) exhibit a strong correlation with Enns' aggregated measure of public punitiveness (.75 or higher); and, 3 ) and have available response data for the years of 2011 and 2012. ${ }^{27}$ Assuming that the strong correlations between the particular survey questions and the gross measure of public punitiveness hold for recent years, this procedure should produce valid estimates of Enns (2014) public punitiveness measure for the updated years of 2011 and $2012 .^{28}$

\section{Federal Incarceration Rate}

As discussed above, it is also plausible that district judges tend to depart from the Guidelines more often when the incarceration rate is high. The logic here is that judges are directly observing the deleterious effects of placing more federal offenders into prison, so they adjust their sentencing behavior to mitigate this problem. Since this reasoning relates to judges' direct impact and exposure to the problem and consequences of over-incarceration, the federal incarceration rate is a preferable measure to the overall incarceration rate. ${ }^{29}$ The federal incarceration rate from 1988-2012, is taken from the Department of Justice's Bureau of Justice Statistics (U.S. DOJ 2015).

\footnotetext{
${ }^{27}$ Specifically, three survey questions from Gallup and the General Social Survey (GSS) meet the above criteria for 2011 and 2012. Two of these questions concerning support for the death penalty and one question concerns whether the courts treat criminals too harsh or not harsh enough. To compute the measure, I take any percentage change in the ratio of punitive responses from the older survey questions, used in Enns (2014) measure, to the newer survey questions, and then incorporate that change into my 2011 and 2012 estimates for public punitiveness. I then repeat this procedure for every question with available data that meets the above criteria.

${ }^{28} \mathrm{In}$ fact, the resultant procedure yields a $2.7 \%$ decrease in the overall public punitiveness measure from 2010 to 2011 , which is consistent with the recent trend, and no change in the public punitiveness measure from 2011 to 2012.

${ }^{29}$ Despite the strengths of the federal measure, to the extent federal judges are able to internalize the incarceration problem that exists in the community beyond the federal system, it is possible that overall incarcerations also have some effect on their decisions.
} 


\section{Crime Rate}

As to changing objective conditions, the crime rate measure is taken using annual data published by the FBI's Uniform Crime Reports from 1988-2012 for the country. Notably, this measure assumes that district judges are able to recognize and internalize changes to the crime rate. Due to district judges' pervasive, if indirect, exposure to crime through their role as criminal case adjudicators, I argue this is a reasonable assumption.

One potential issue with the crime rate measure is the fact that huge variation exists in crime rate trends across different parts of the country. Since district judges are assigned to a specific geographic area, it is possible that they are sensitive to the local crime rate but not the national crime rate. Despite this possibility, due to the fact that all other variables are measured at the national level, this design ${ }^{30}$ assumes that the annual crime-rates measure will average out any diverging and regional trends.

Another issue regarding the crime rate, incarceration rate, and public punitiveness measures merits brief discussion. For all three variables, annual data is compiled in calendar years as opposed to fiscal years. The federal government's fiscal year operates from October 1September 30, and as such, the Sentencing Commission publishes its annual data and reports based upon sentences issued during this time period. This mismatch in annual data creates a potential difficulty when making causal inference in time-series analysis (Skog 2003).

In the present models, I chose to correspond the fiscal-year variables with the previous calendar year variables. Although this decision creates only a three month overlap for corresponding variables, as opposed to a nine month overlap, it is preferable for two reasons.

First, it prevents the inclusion of elements of input variables that occur after district judges issue

\footnotetext{
${ }^{30}$ For a test of whether state/local crime rates impacts district judges' sentencing decisions, see Chapters 3-4.
} 
sentences. Obviously, it makes no theoretical sense that the independent variables of crime, incarceration, or public opinion could be affecting district judges, if the trends in these independent variables have not yet occurred when sentencing decisions are made.

This first reason for this decision is closely related to the second reason. Namely, the logic of this theory is that as district judges begin to become sensitive to the public sentiment or pertinent objective conditions surrounding them, they alter their individual sentencing decisions. It is implausible that this reaction would occur immediately with no lag time. Accordingly, corresponding the preceding calendar year for these input variables with the remaining variables is the better option than corresponding the same fiscal and calendar years.

\section{Partisanship of District Judges}

Although my theoretical perspective de-emphasizes ideology and party, sentencing preferences are potentially related to partisanship of the judges (Fischman \& Schanzenbach 2011). If this is the case, we would expect the proportion of district judges appointed by Democratic presidents to correspond with downward Guideline departures. To measure this series, I calculate the proportion of active federal district judges appointed by a Democratic President for each year from 1988-2013. In order to account for judges appointed/retiring within the year in question, I calculate this proportion at the halfway-point through each fiscal year (April 1). Note this measure assumes both that there are roughly equal sentencing decisions made in each half of the fiscal year and that there are no partisan differences in whether judges retire in the first or second half of the fiscal year. ${ }^{31}$

\footnotetext{
${ }^{31}$ The sentencing data (USCC 1995-2014), in addition to past research evidencing that district judges do not retire strategically (Yoon 2006), suggest these are both reasonable assumptions.
} 


\section{Partisanship of Circuit Judges}

There is also the possibility that district judges make sentencing decisions strategically and avoid deviating from the Guidelines when it is likely they will be overturned on appeal. Both Epstein, et. al. (2013) and Fischman \& Schanzenbach (2011) find that the proportion of Democrat-appointees sitting on the court of appeals circuit with appellate jurisdiction over the sentencing district judge was positively associated with downward departure rates. As discussed above, this finding may be evidence of strategic behavior of district judges who do not want their sentences to be overturned or it may simply be reflective of the observed relationship between circuit court ideology and region.

To provide insight into these alternative theories, I also include a partisan variable for circuit court judges who do not make initial sentencing decisions. This variable is measured simply as the proportion of circuit judges appointed by a Democratic President in each fiscal year from 1988-2013, as of April 1. ${ }^{32}$ If strategic behavior is truly the driving factor behind the circuit partisanship/departure rate relationship, we should expect to find that changes to the aggregate partisan proportion of appellate judges affects aggregate district judge sentencing behavior over time.

\section{Methods}

To test determinants of Guideline departures over time, I employ an autoregressive integrated moving average with exogenous variables (ARIMAx) model. ${ }^{33}$ An ARIMAx model is similar to the Auto Regressive Integrated Moving Average Model (ARIMA) of Box and Jenkins (1970), except that it allows for the inclusion of additional exogenous covariates based upon

\footnotetext{
${ }^{32}$ As with the annual measure of the partisanship of the district courts, above, this proportion is calculated on April 1 of each year, because it is the halfway point of the federal fiscal year.

${ }^{33}$ Also sometimes referred to as “dynamic regression” Pankratz (2012).
} 
cross-correlations between these covariates and the response series. (Andrews, et. al. 2013; Lee, et. al. 2013).

There are several factors that make an ARIMAx dynamic regression model appropriate in this case. First, a simple multiple linear regression model of judicial departure rates from the Guidelines, with the above-referenced independent variables included, results in positively correlated residuals, which violates assumptions of the linear regression model. ${ }^{34}$ An ARIMAx model is similar to a multiple linear regression model, except that it includes one or more autoregressive (AR) terms or moving average (MA) terms. Inclusion of these terms can be used to ensure that the correlated residuals of a time series model can be translated into white noise.

Secondly, the Guideline departure rate series exhibits substantial variation over time (See Figure 1) with many different plausible exogenous input variables explaining this trend (See above). These are the type of situations when ARIMAx models can potentially be utilized (Grillezoni 1993). Furthermore, ARIMAx models allow for both lagged and decaying effects of covariates (Feng, et. al. 2013; Lee, et. al. 2013; Clavijo 1994). As we would not expect any effects of the input variables to be either immediate or permanent on district judges, this inclusion of lagged and decaying effects is also appropriate. Finally, due to the limited number of observations in the time series, a more complex model, such as a vector auto regressive (VAR) model, which uses multiple equations to estimate the effect of separate series at various lags, is inappropriate (Rautava 2004).

Modeling with ARMA parameters requires that the modeled series be stationary, with a constant mean and variance over time (Copertwait \& Metcalfe 2009). However, as can be

\footnotetext{
${ }^{34}$ More specifically, a simple linear regression model of total departure rates, with all of the above noted variables included, results in a Durbin Watson statistic of 0.55., suggesting strong, positive serial correlation in the residuals. Accordingly, a simple linear model of departure rates does not comport with the assumption of linear regression of independently distributed residuals.
} 
clearly seen from Figure 1, the Guideline departure rate series is not stationary, as it exhibits substantial drift upwards over time. Indeed, it is this drift that the present model seeks to explain. To address this issue, the departure rate series is differenced so that the series reflects annual changes in departure rates rather than annual levels of departure rates. The first differencing technique of the departure rate successfully creates a stationary time-series, which allows for ARIMA modeling. As is advisable for ARIMAx model-building, the input variables are also differenced using the same method as was used on the dependent variable (Andrews, et. al., 2013). Thus, the model represents the effects of changes in the input variables on changes in judicial departure rates at various lags.

One disadvantage of the ARIMAx models is that, because the value of the dependent variable is dependent on prior values of the dependent variable, the coefficients of the input variables cannot be interpreted intuitively as a one unit change in the input variable producing a one-unit change in the dependent variable (Enders 2008). However, as these models are exploratory, seeking to test the effect of previously untested variables on judicial behavior, the significance tests themselves are worthwhile endeavors.

\section{Results}

Recall that two different series are used as a measure of district judge punitiveness: Total Departures and Judge-Initiated Downward Departures. Results from two different ARIMAx model specifications for the Total Downward Departures series are first presented in Table 2 below. The first column of Table 2 includes a model specification with only the policy change/partisanship of the judiciary input variables included. The second column of the model represents the full specification, which adds the hypothesized variables: annual change in the incarceration rate, the annual change in the crime rate, and the annual change in the Enns (2014) 
measure of public punitiveness. Both models represent the best fitting ARIMA model order, or the one with the lowest AIC (Akaikie Information Criteria). ${ }^{35}$

Before examining the effect of the input variables, note that the differenced series modeled in Table 2 include two significant moving average parameters, which are required to make the residuals of the series white noise. After these parameters are included, the auto correlation function plots for the models produce no significant autocorrelation at any lags for the selected series, and each of the Ljung-Box Tests resulted in a failure to reject the null hypothesis of independently distributed residuals. ${ }^{36}$ Thus, the observed serial correlation in the residuals of the simple linear regression model is no longer present.

\section{[Table 2 about here]}

Turning to the effect of the input series on below-Guideline sentences, there is some evidence for the hypothesis that increased levels of federal incarceration are associated with higher rates of downward departures. The positive and statistically significant coefficient for the incarceration rate in the second column of Table 2 suggests that increase in the incarceration rate leads to increases in downward departures from the Guidelines.

Despite the evidence supporting the effect of incarceration rates, results do not support the hypotheses that either the crime rate or public punitiveness are negatively associated with rates of below-Guideline sentences. As can be seen from Table 2, the negative coefficient for the crime rate variable is in the expected direction but fails to obtain statistical significance. Additionally, contrary to expectations, the coefficient for public punitiveness is positive.

\footnotetext{
${ }^{35}$ See Bozdogan (1987) for a full discussion of AIC and how it works well as a test of model strength in ARIMA models.

${ }^{36}$ The $p$ values for the Ljung Box Test are: 0.80, 0.34 for the two models respectively. Thus, we fail to reject the null hypothesis of independently distributed residuals.
} 
Not surprisingly, we do observe negative, significant coefficients for the legal policy change of the enactment of the PROTECT Act. This finding is consistent with past research regarding district judge adherence to the Guidelines and suggests that the PROTECT Act constrained district judges' ability to depart from the Guidelines, (Tiede 2009, Fischman \& Schanzenbach, 2011). On the other hand, neither model finds that Booker significantly increased proportions of below-Guideline sentences, which is contrary to expectations (See Epstein, et. al., 2013).

The results in Table 2 are also somewhat mixed as to the effect the partisanship of the judiciary has on downward departure rates. While the more parsimonious model has a significant positive coefficient for the proportion of Democratic-appointees on the district court, this statistical significance disappears in the full model. Neither model finds a significant relationship between Democratic-appointees on the circuit court and departure rates.

In comparing the two models, the inclusion of the newly added input variables does nominally improve the strength of the model. The AIC in the second column is lower than the AIC in first column, which suggests that the additional parameters add explanatory power to predicting changes in departure rates. The AIC measure of model strength is parameter efficient, so even after being "penalized" for including the additional variables, the model improves (Bozdogan 1987).

Table 3 represents a similar set of models, but this time the dependent variable excludes downward departures based on "substantial assistance" to the government. Recall that this series excludes certain downward departures from the Guidelines, wherein the prosecution recommends and sponsors a below-Guideline sentence due to the offender providing information to the government related to other criminals. Thus, in contrast to Table 2, Table 3 does not 
represent the full gamut of judicial guideline application but instead excludes a sizable minority of cases wherein the government recommends a reduced sentence to the judge based on the offender's substantial assistance.

As with the models of in Table 2, both ARIMAx models in Table 3 of Judge-Initiated Downward Departures are free of autocorrelation. The autocorrelation function plots of the models' residuals show no significant lags and results of the Ljung-Box tests provide no evidence of correlated residuals. $^{37}$

\section{[Table 3 about here]}

The two models of Judge-Initiated Downward Departures presented in Table 3 produce similar results to those observed in Table 2. As with the Total Departure Model presented in Table 2, the positive and significant coefficient for the incarceration rate suggests that higher levels of incarceration are associated with district judges issuing more below-Guideline sentences. The other two input variables of interest (public punitiveness and the crime rate), however, fail to reach statistical significance.

One difference between the models of the Total Downward Departure series presented in Table 2 and the Judge-Initiated Downward Departure series in Table 3 is that the Booker coefficient is positive and significant in Table 3. This is consistent with past research suggesting that judges increased their proportion of below-Guideline sentences in response to the increased discretion they received after Booker (Epstein, et. al. 2013).

\section{Discussion}

The results of the models presented above provide some support for the incarceration rate hypothesis suggesting increased incarceration is associated with more lenient district judge

\footnotetext{
${ }^{37}$ The $p$ values for the Ljung Box Test are: 0.77 and 0.89 for the two models respectively. Thus, we fail to reject the null hypothesis of independently distributed residuals.
} 
sentencing. The incarceration rate variable reaches statistical significance in both the Total Downward Departure model in Table 2 and the Judge-Initiated Downward Departure model in Table 3. Thus, there is some preliminary evidence that increased federal incarceration has softened the sentencing behavior of district court judges over time.

However, when viewed overall, the results are certainly not strongly supportive of the theoretical perspective of contextual influence. Specifically, results did not support the hypotheses that either the crime rate or public punitiveness are positively associated with punitive judicial behavior. Overall, there is little to no support for the "representational model" of judicial behavior suggesting that judges' decisions are representative of the people (Silver and Shapiro 1984; Gibson 1980; Vines 1960).

While it is quite possible that the expected variables simply do not influence judicial behavior as theorized, it should be noted that there are other potential explanations for the failure of the above tests to provide strong results. First, the limited number of observations in the series makes the results susceptible to data from a single variable in a single year. This problem is exacerbated by the policy changes that occurred in the early 2000's (the PROTECT Act and Booker) that impacted departure rates. To address the small sample size issue, Chapter 3 employs a panel design, utilizing data from different US district courts throughout the country in different years. This method vastly increases the sample size and could perhaps lead to different results.

Second, it is possible that district judges do respond to crime rates and public punitive attitudes, but they are concerned with crime and opinion at the local level only. Indeed, this finding may be what would be expected by scholars of district court behavior who note their connection local communities (Kritzer \& Zemans 1993). If this is the case, and changes in public 
punitiveness and the crime rate vary throughout the country, the results from these national-level models will not be able to fully capture these variables' import. Once again, to test whether this is the case, models presented in Chapter 3 will test the potential impact of localized crime rates and local public preferences, as opposed to any national-level changes.

Finally, the results do indirectly support one aspect of my theoretical perspective. While failing to strongly support the specific hypotheses, the results do tacitly suggest that district judge behavior is complex and cannot be easily captured by a handful of variables. Stated differently, minimal change in judicial sentencing behavior over the past few decades was explained by the partisan and policy-change variables. However, and notably, the inclusion of the additional contextual variables into models of departure rates resulted in improvements in the models' explanatory power. This model-strength improvement implies that the hypothesized contextual variables should be subjected to future testing using alternative methods to better determine their possible relationship with district judges' sentencing behavior.

In sum, the results of this test were somewhat disappointing but do lay some initial groundwork for future empirical testing. Notwithstanding some promising results regarding the effect of incarceration rates, the most reasonable interpretation of the findings is that the strong trend exhibited in Figure 1 remains largely unexplained. Accordingly, future scholars should follow the advice of Silver and Shapiro (1984) and continue to use new methods and probe additional variables that may help explain causes of district judges' sentencing decisions.

\section{References}

Andrews, Bruce H., Matthew D. Dean, Robert Swain, Caroline Cole. 2013. "Building ARIMA and ARIMAX Models, Predicting Long-Term Disability Benefit Application Rates in the Public/Private Sectors." Society of Actuaries Executive Summary. Portland, ME.

Baum, Lawrence. 2006. Judges and Their Audiences. Princeton, NJ: Princeton University Press.

Baum, Lawrence. 1997. The Puzzle of Judicial Behavior. Ann Arbor: University of Michigan Press. 
Bozdongan, Hamparsum. 1987. "Model Selection and Akaike's Information Criterion (AIC): The General Theory and its Analytical Extensions." Psychometrika 42:345-370.

Box, George and Gwilym Jenkins. 1970. "Forecasting with Econometric Methods: Folklore versus Fact with Discussion" Journal of Business 51:549-600.

Clavijo, Sergio. 1994. "Relative price and inflation uncertainty in Colombia: A case of chronic moderate inflation 1970-1990." Estudios Económicos: 119-136.

Cook, Beverly B. 1973. "Sentencing Behavior of Federal Judges: Draft Cases, 1972." Cincinnati Law Review 42:597-633.

Cook, Beverly B. 1977. "Public Opinion and Federal Judicial Policy." American Journal of Political Science 21: 567-600.

Cowpertwait, Paul S.P. \& Andrew V. Metcalfe. 2009. Introductory Time Series with R. New York: Springer Science \& Business Media.

Enns, Peter. 2014. "The Public's Increasing Punitiveness and Its Influence on Mass Incarceration in the United States." American Journal of Political Science 58:857-872.

Enders, Walter. 2008. Applied Econometric Time Series. Hoboken, NJ: John Wiley \& Sons.

Epstein, Lee \& Jack Knight. 2003. The Choices Justices Make. Washington, D.C.:CQ Press.

Epstein, Lee, William M. Landes, \& Richard A. Posner. 2013. The Behavior of Federal Judges. Cambridge, MA: Harvard University Press.

Feng, Zhujing, Keith E. Schilling, and Kung-Sik Chan. 2013. "Dynamic Regression Modeling of Daily NitrateNitrogen Concentrations in a Large Agricultural Watershed." Environmental Monitoring and Assessment 185(6): 4605-4617.

Fischman, Joshua B. \& Max Schanzenbach. 2011 "Do Standards of Review Matter? The Case of Federal Criminal Sentencing." Journal of Legal Studies 40:405-437.

Freeborn, Beth A., and Monica E. Hartmann. 2010. "Judicial Discretion and Sentencing Behavior: Did the Feeney Amendment Rein In District Judges?” Journal of Empirical Legal Studies 7:355-378.

Gibson, James L. 1980. "Environmental Constraints on the Behavior of Judges: A Representational Model of Judicial Decision Making.” Law \& Society Review 14:343-370.

Giles, Micheal W., Virginia A. Hettinger, and Todd Peppers. 2001. "Picking Federal Judges: A Note on Policy and Partisan Selection Agendas." Political Research Quarterly 54(3):623-641.

Grillezoni, Carlo. 1993 "ARIMA Processes with ARIMA Parameters." Journal of Business and Economic Statistics. 11:235-250.

Johnson, Brian. 2003. "Racial and Ethnic Disparities in Sentencing Departures Across Modes of Conviction." Criminology 41:449-88.

Johnson, Brian, Jeffery T. Ulmer, and John H. Kramer. 2008. “The Social Context of Guidelines Circumvention: The Case of Federal District Courts." Criminology 46(3):737-783.

Kim, Pauline T. 2009. "How Should We Study District Judge Decision-Making?." Washington University Journal of Law and Policy 29:83-121. 
Kritzer, Herbert. 1978. "Political Correlates of the Behavior of Federal District Judges: A Best Case Analysis." Journal of Politics 40:25-58.

Kritzer, Herbert M., and Frances Kahn Zemans. 1993. "Local Legal Culture and the Control Of Litigation." Law \& Society Rev. 27:535-558.

Kuklinski, James H. and John E. Stanga. 1979. "Political Participation and Government Responsiveness: The Behavior of California Superior Courts.” American Political Science Review 73:1090-1099.

Lee, Hu Suk, Moon Her, Michael Levine, and George E. Moore. 2013. "Time Series Analysis of Human and Bovine Brucellosis In South Korea From 2005 to 2010." Preventive Veterinary Medicine 110(2): 190-197.

Lynch, Mona and Marisa Omori. 2014. "Legal Change and Sentencing Norms in the Wake of Booker: The Impact of Time and Place on Drug Trafficking Cases in Federal Court." Law and Society Review 48 (2):411-445.

Mishler, William, and Reginald S. Sheehan. 1993. "The Supreme Court as a Countermajoritarian Institution? The Impact of Public Opinion on Supreme Court Decisions." American Political Science Review 87(1):87-101.

Pankratz, Alan. 2012. Forecasting With Dynamic Regression Models. Hoboken, NJ: John Wiley \& Sons.

Peltason, Jack AW. 1971. Fifty-Eight Lonely Men: Southern Federal Judges and School Desegregation. Urbana, IL: University of Illinois Press.

Posner, Richard A. 1993. "What do Judges and Justices Maximize? (The Same Thing Everybody Else Does)." Supreme Court Economic Review 3:1-41.

Rautava, Jouko. 2004. "The Role of Oil Prices and the Real Exchange Rate in Russia's Economy-A Cointegration Approach." Journal of Comparative Economics. 32:315-327

Rehavi, M. Marit, \& Sonia Starr. 2012. "Racial Disparity in Federal Criminal Charging and Its Sentencing Consequences," U of Michigan Law \& Econ, Empirical Legal Studies Center Paper (12-002)

Rowland, C.K. \& Robert A. Carp. 1996. Politics and Judgment in Federal District Courts. Lawrence, KS: University of Kansas Press.

Schanzenbach, Max M., and Emerson H. Tiller. 2007. "Strategic Judging under the U.S. Sentencing Guidelines: Positive Political Theory and Evidence." Journal of Law, Economics, and Organization 23:24-56.

Segal, Jefferey A. and Harold J. Spaeth. 2002. The Supreme Court and the Attitudinal Model Revisited. New York: Cambridge University Press.

Silver, Charles and Robert Shapiro. 1984. "Public Opinion and the Federal Judiciary: Crime, Punishment, and Demographic Constraints." Population Research and Policy Review 3:255-280.

Sisk, Gregory S., Michael Heise, and Andrew P. Morriss. 1998. "Charting the Influences on the Judicial Mind: An Empirical Study of Judicial Behavior.” New York University Law Review 73: 1377-1500.

Skog, Ole-Jo. 2003. "Alcohol consumption and fatal accidents in Canada, 1950-98." Addiction 98(7): 883-893.

Songer, Donald R. 1982. "Consensual and Nonconsensual Decisions in Unanimous Opinions of the United States Courts of Appeals." American Journal of Political Science 26:225-239.

Spriggs, James \& Paul Wahlbeck. 1995. "Calling it Quits: Strategic Retirement on the Federal Courts of Appeals, 1893-1991.” Political Research Quarterly 48:573-597. 
Stith, Kate \& Jose A. Cabranes. 1998. Fear of Judging: Sentencing Guidelines in the Federal Courts. Chicago, Il: University of Chicago Press.

Tiede, Lydia B. 2009. The Impact of the Federal Sentencing Guidelines and Reform: A Comparative Analysis. Justice System Journal 30:34-49.

Ulmer, Jeffery T. \& Mindy S. Bradley. 2006. "Variation in Trial Penalties Among Serious Violent Offenses." Criminology 44:631-670.

Ulmer, Jeffery T., \& Brian Johnson, B. 2004. Sentencing In Context: A Multilevel Analysis. Criminology 42: 137178.

United States Department of Justice. 2015. "Prisoners in 2014. Accessible at: http://www.bjs.gov/content/pub/pdf/p14.pdf

United States Sentencing Commission datafile. 1995-2014. Sourcebook of Federal Sentencing Statistics. Retrieved from: http://www.ussc.gov/Research_and_Statistics/Annual_Reports_and_Sourcebooks/Archives.cfm

United States Sentencing Commission. 2012. Final Report of the Impact of United States v. Booker on Federal Sentencing. Washington, D.C.: United States Sentencing Commission.

United States Sentencing Commission. 2010. Demographic Differences in Federal Sentencing Practices: An Update of the Booker Report's Multivariate Regression Analysis. Washington, DC: US Sentencing Commission.

Vines, Kenneth. 1964. "Federal District Judges and Race Relations Cases in the South." Journal of Politics 26:337-357.

Weinstein, Ian. 1998. "Substantial Assistance and Sentence Severity: Is There a Correlation Substantial Assistance." Federal Sentencing Reporter Rep 11: 83-85.

Yoon, A. 2006. "Pensions, Politics, and Judicial Tenure: An Empirical Study of Federal Judges, 1869-2002." American Law and Economics Review 8:143-180. 
Table 1: FY 2012 Sentencing Table

*Source: USSC

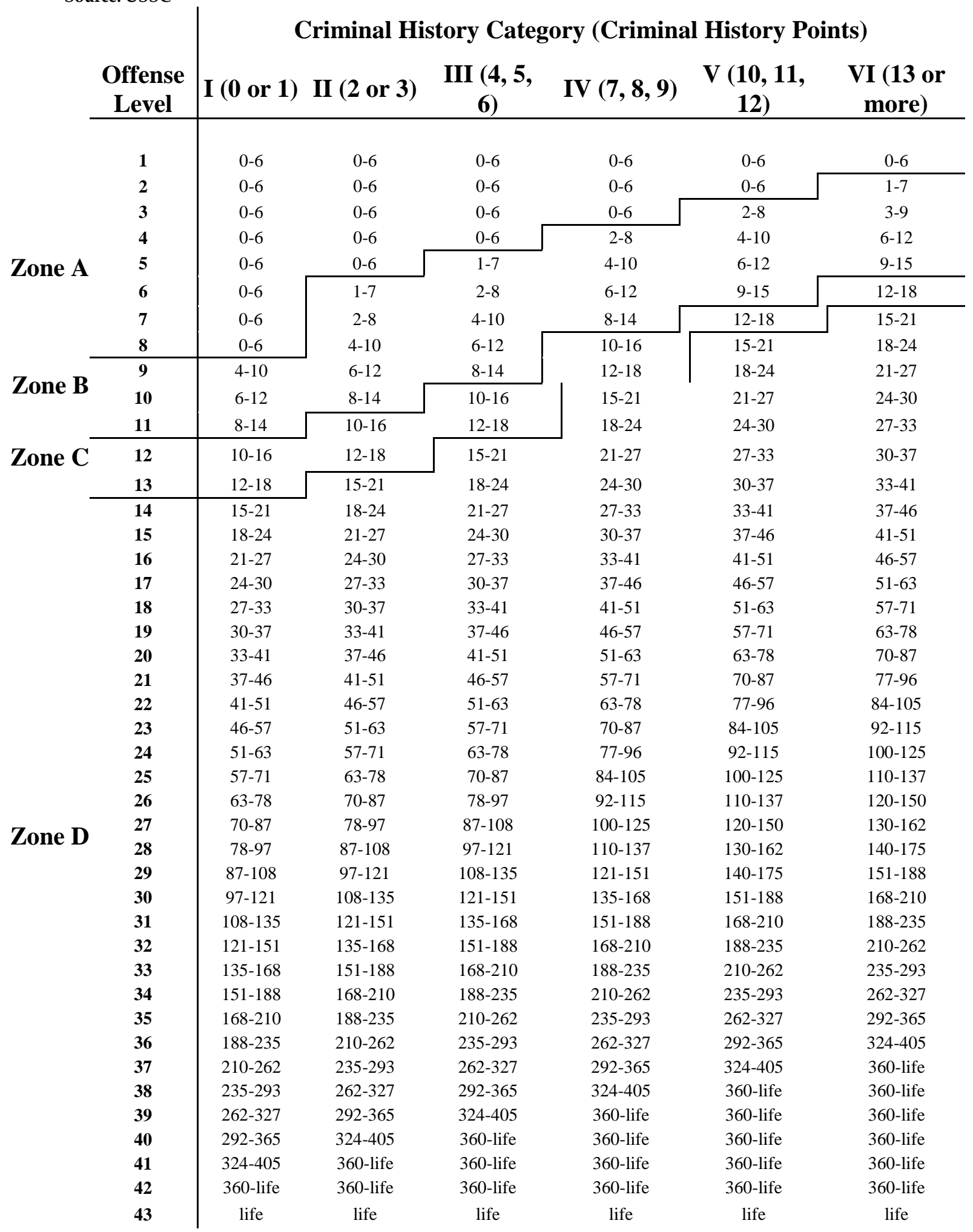


Figure 1: Percentage of Offenders Sentenced Below Guideline Recommended Range: 1988-2014

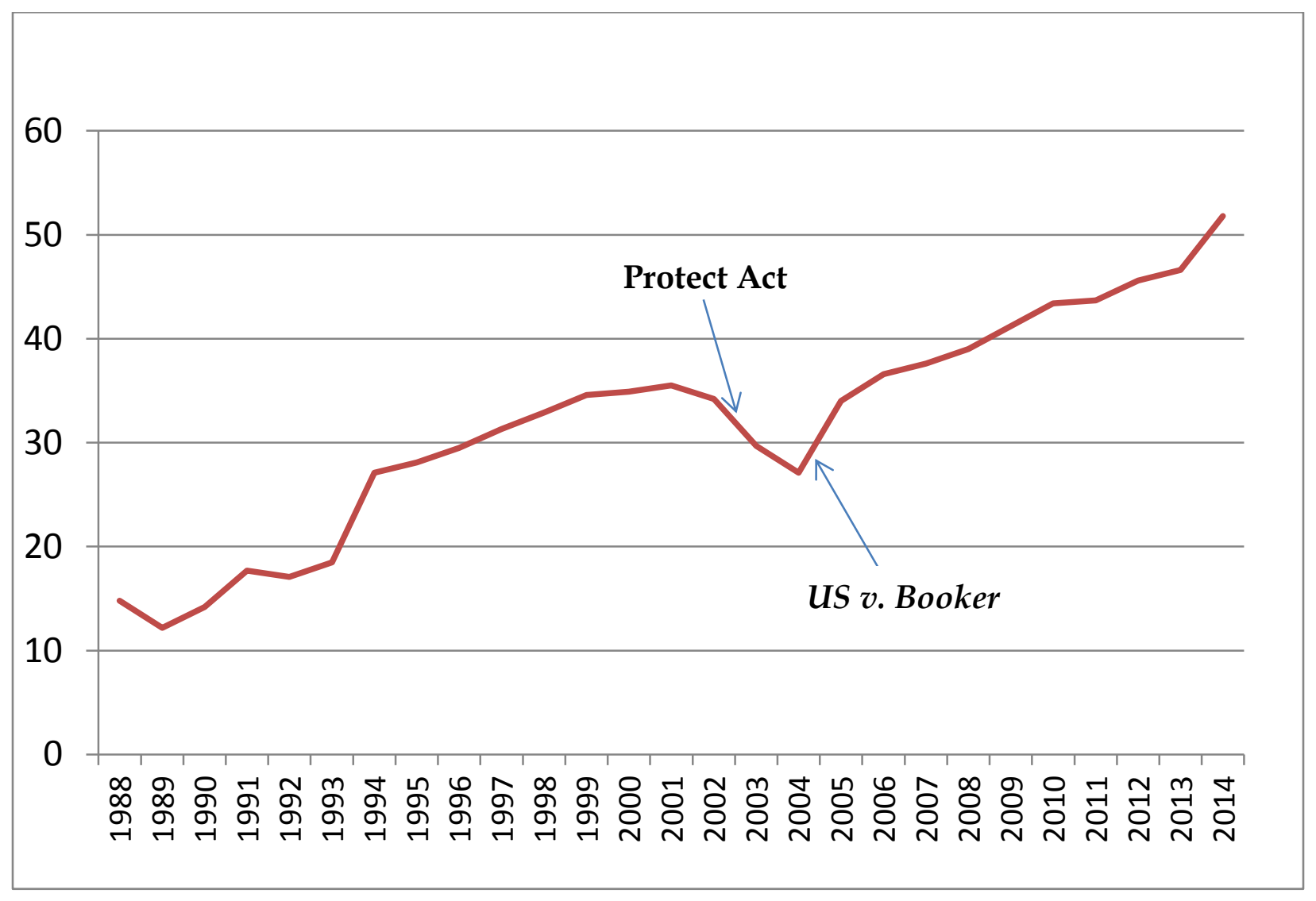


Table 2: Dynamic Regression Determinants of Total Downward Departure Rates (FY 1988-2013)

\begin{tabular}{|c|c|c|}
\hline Variable & (1) & (2) \\
\hline Booker & $\begin{array}{l}3.95 \\
(4.01)\end{array}$ & $\begin{array}{l}0.87 \\
(4.73)\end{array}$ \\
\hline PROTECT Act & $\begin{array}{l}-5.88^{* *} \\
(2.14)\end{array}$ & $\begin{array}{l}-4.28^{*} \\
(2.35)\end{array}$ \\
\hline DemDist \% & $\begin{array}{l}0.19^{* *} \\
(0.06)\end{array}$ & $\begin{array}{l}0.10 \\
(.12)\end{array}$ \\
\hline DemCirc \% & $\begin{array}{l}-0.04 \\
(0.09)\end{array}$ & $\begin{array}{l}0.12 \\
(0.12)\end{array}$ \\
\hline Incarc. Rate & - & $\begin{array}{l}0.44^{*} \\
(0.23)\end{array}$ \\
\hline Crime Rate & - & $\begin{array}{l}-0.03 \\
(0.14)\end{array}$ \\
\hline Public Punitiveness & - & $\begin{array}{l}0.20 \\
(0.10)\end{array}$ \\
\hline ARIMA Order $(p, d, q)$ & $(0,1,2)$ & $(0,1,2)$ \\
\hline $\mathrm{MA}(1)$ & $\begin{array}{l}0.62^{* *} \\
(0.18)\end{array}$ & $\begin{array}{l}0.98^{* *} \\
(0.31)\end{array}$ \\
\hline $\mathrm{MA}(2)$ & $\begin{array}{l}1.00^{* *} \\
(0.19)\end{array}$ & $\begin{array}{l}1.00^{* *} \\
(0.20)\end{array}$ \\
\hline $\begin{array}{l}\text { MSE } \\
\text { (Mean Squared Error) }\end{array}$ & 1.07 & 0.80 \\
\hline Degrees of Freedom & 19 & 16 \\
\hline AIC & 86.93 & 86.07 \\
\hline Note: standard errors in parentheses $* \mathrm{p}<.05 * * \mathrm{p}<.01$ & 1 (one-tailed tests) & \\
\hline
\end{tabular}


Table 3: Dynamic Regression Determinants of Judge-Initiated Departure Rates (FY 1988-2013)

\begin{tabular}{|c|c|c|}
\hline Variable & (1) & (2) \\
\hline Booker & $\begin{array}{l}6.95^{*} \\
(3.52)\end{array}$ & $\begin{array}{l}4.38 \\
(3.69)\end{array}$ \\
\hline PROTECT Act & $\begin{array}{l}-2.62 \\
(1.95)\end{array}$ & $\begin{array}{l}-1.53 \\
(2.18)\end{array}$ \\
\hline DemDist \% & $\begin{array}{l}0.00 \\
(0.05)\end{array}$ & $\begin{array}{l}-0.04 \\
(0.06)\end{array}$ \\
\hline DemCirc. \% & $\begin{array}{l}0.02 \\
(0.07)\end{array}$ & $\begin{array}{l}0.16^{*} \\
(0.08)\end{array}$ \\
\hline Incarc. Rate & - & $\begin{array}{l}0.41^{*} \\
(0.15)\end{array}$ \\
\hline Crime Rate & - & $\begin{array}{l}-0.01 \\
(0.01)\end{array}$ \\
\hline Public Punitiveness & - & $\begin{array}{l}0.10 \\
(0.07)\end{array}$ \\
\hline ARIMA Order $(p, d, q)$ & $(0,1,2)$ & $(0,1,2)$ \\
\hline MA(1) & $\begin{array}{l}0.75^{* *} \\
(0.16)\end{array}$ & $\begin{array}{l}1.11^{\text {** }} \\
(0.30)\end{array}$ \\
\hline $\mathrm{MA}(2)$ & $\begin{array}{l}1.00^{* *} \\
(0.20)\end{array}$ & $\begin{array}{l}1.00^{* *} \\
(0.21)\end{array}$ \\
\hline $\begin{array}{l}\text { MSE } \\
\text { (Mean Squared Error) }\end{array}$ & 0.76 & 0.60 \\
\hline Degrees of Freedom & 19 & 16 \\
\hline AIC & 78.78 & 78.5 \\
\hline Note: standard errors in parentheses $* \mathrm{p}<.05 \quad * * \mathrm{p}<.01$ & 1 (one-tailed tests) & \\
\hline
\end{tabular}




\title{
Chapter 3:
}

\section{"Of Time and Space: How Localized and Temporal Factors Influence Federal Judges' Criminal Sentencing Decisions."}

\begin{abstract}
:
Recent research on sentencing outcomes in federal district courts suggests that sentencing practice is complex and contingent upon the location of the federal district. While researchers have identified several sources of this inter-district variation, potentially relevant sociopolitical characteristics have not been fully explored. I argue that district court judges, despite being unelected, are likely to be sensitive to salient sociopolitical inputs. Using a panel-design, pooling data from ninety (90) federal districts across sixteen (16) years, this paper tests whether two such sociopolitical variables: 1) the state crime rate and 2) state citizen ideology, affect the harshness of sentences through judicial application of the US Sentencing Guidelines. Results suggest that both the crime rate and the ideology of the citizens are associated with judicial departures from the Guidelines. Results further suggest that while there is substantial inter-district variation in judicial behavior, sociopolitical factors have an effect over-time within districts. Broadly, these findings suggest that federal district court judges may be accounting for broader sociopolitical factors in their individual decisions.
\end{abstract}




\section{Introduction}

Trial judges are members of communities. Trial judges in many state-court systems in the United States are directly elected by the people of these communities. In the federal system, trial judges, or "district court judges," are instead appointed by the President and confirmed by the US Senate. Despite this lack of an electoral connection to their communities, district court judges are often long-time residents of the geographical areas to which they are appointed (Sivler and Shapiro 1984). The federal judiciary is divided into ninety distinct geographic districts within the fifty U.S. States and the District of Columbia. ${ }^{38}$ Accordingly, federal district court judges are political actors both within a nationwide federal system and within much smaller geographic areas.

For obvious reasons, a substantial body of research on Congress has focused on the extent to which members differ and/or are reflective of the views of the district or state they represent (Miller and Stokes 1963; Fiorina 1974; Mayhew 1974; Bartels 1991; Clinton 2006). Yet, while these questions have been explored by federal judicial scholars, especially in prior decades (Rosenberg 1991; Silver and Shapiro 1984; Cook 1973, 1971; Vines 1964), there have been comparatively fewer attempts to explain whether national variation in federal district judge behavior is explained by social and political qualities of the location where the judges sit. ${ }^{39}$

Accordingly, the broader question of this chapter is: to the extent that we observe national variation in district court judicial behavior, how much of said variation can be explained

\footnotetext{
${ }^{38}$ There are also four (4) additional districts for the U.S. territories of Puerto Rico, Guam, the US Virgin Islands, and the North Mariana Islands.

${ }^{39}$ Criminologists and Criminal Justice scholars interested in sentencing practice have more thoroughly examined national variation. See Johnson, et. al. (2008); Wu and Spohn (2010). However, as explained much more thoroughly, infra, there is a need to update and build upon these studies.
} 
by district or statewide features of the community? Thus, rather than attempting to understand judicial behavior by focusing on national or case-specific factors, this paper takes a less-utilized "middle" approach and focuses on qualities of states and districts. I argue these more localized, but not necessarily case-specific, factors are influential on federal district judge behavior. It is of course true that we would expect social and political characteristics of states and districts to affect elected political actors, such as members of Congress, more than unelected political actors, such as federal district court judges. Still, district judges are a unique type of policymaker in that they operate within a national political system, but exercise jurisdiction over only a geographically defined area. Thus, it is worthwhile to examine the potential impact characteristics of these local areas have on district judges.

Criminal sentencing, as a policy area, may provide unique and powerful insight into how characteristics of a local area might impact district judges. First, the United States Sentencing Commission ("USSC") has kept a wealth of data on the sentencing practices of each federal judicial district This data provides researchers with a rare opportunity to compare judicial decisions in different districts using objectively coded data.

Second, cursory examination of the raw sentencing data reveals extreme inter-district variation with respect to how criminals are sentenced throughout the country. This variation is certainly not solely the product of differences in judicial behavior, as different areas of the country have differing profiles of both crimes committed and types of offenders (USSC 2012). Still, recent research has observed variation even when controlling for some or all of these conflating factors (Wu and Spohn 2010; Tiede 2009; Kautt 2002). Moreover, the considerable 
size of the variation in different areas of the country is itself grounds for examination of the potential effect of geographic-specific sociopolitical factors on judicial sentencing practices. ${ }^{40}$

Finally, criminal sentencing is an incredibly important duty of federal district court judges. The rise of the federal prison population through approximately the last twenty five years is striking. In 1988 federal prisons held approximately 50,000 inmates. By 2012, that number had nearly quadrupled to over 196,000 inmates. The rates of federal incarceration have also risen markedly from roughly 20 inmates per 100,000 US residents to more than 60 per 100,000 (US DOJ 2015). While several factors outside of judicial control, such as increased prevalence of mandatory minimum sentencing, are largely responsible for the upward trend in incarceration, district judges possess some power to either exacerbate or mitigate these effects (Lynch and Omori 2014; USSC 2012). To the extent we believe high levels of incarceration are a societal problem, the potential effects of localized sociopolitical variables on either contributing to or alleviating this problem is certainly a worthwhile inquiry.

In this chapter, I focus on two state-level sociopolitical variables that may impact sentencing decisions on judges within those states: (1) the crime rate; and (2) the ideology of the citizens of the state. These two factors provide potentially important explanations for interdistrict sentencing variation. Testing potential effects of the crime rate is predicated upon the notion that judges are sensitive to relevant environmental conditions occurring in their community when ruling on cases (Kritzer 1978). Accordingly, judges who live and work in higher crime areas are likely to seek to address this crime problem by punishing criminal

\footnotetext{
${ }^{40}$ The size of the variation can perhaps best be illustrated by an example from the distribution of judge-initiated departure rates amongst districts in FY 2013. At the $25^{\text {th }}$ percentile, or a typically Guideline-adherent district, offenders received a judge-initiated downward departure approximately $15 \%$ of the time. At the $75^{\text {th }}$ percentile, in a typically Guideline-resistant district, offenders received a judge-initiated departure $27 \%$ of the time. Thus, offenders are almost twice as likely to receive a judge-initiated downward departure in a Guideline-resistant district than a Guideline-adherent district.
} 
offenders with longer sentences. Moreover, irrespective of the lack of evidence that long sentences deter crimes in the future, district judges are probably more likely to be receptive to the general deterrence justification for sentencing, when the crime problem is severe. Finally, there is some qualified support for the proposition that higher crime rates cause judges to issue harsher sentences, albeit for elected judges (Ulmer and Bradley 2006; Gibson 1980).

The logic underlying state citizen ideology is based upon the "representational model" of judicial behavior suggesting that judges are reflections of the communities in which they sit (Rowland \& Carp 1996; Goldman and Sarat 1978; Silver and Shapiro 1984; Peltason 1971; Vines 1964). ${ }^{41}$ Although the question of public influence on unelected judges is far from settled, and general ideology is by no means a perfect proxy for treatment towards criminals, some recent evidence suggests that unelected officials in the criminal justice system may be responsive to public opinion (Enns 2014; Nicholson-Crotty, et. al. 2009; Johnson, et. al. 2008).

It is worth noting at the outset that these two variables are not thought to be exclusive of other geographic-specific effects on judicial sentencing. Other potentially relevant factors may include economic factors (Johnson, et. al. 2008) or local sentiment in the legal community regarding crime and punishment (Kautt 2002; Posner 1993; Baum 2006). ${ }^{42}$ Still, the crime rate and citizen ideology are measurable factors that vary widely across states. They provide an excellent starting point for testing whether and to what extent federal judges respond to sociopolitical factors when making decisions in individualized cases.

The outline of this chapter will proceed as follows. First, I develop the theoretical framework of why district judges may be sensitive to environmental conditions. Second, I give a necessary background of sentencing policy and procedures in the United States. Third, I

\footnotetext{
${ }^{41}$ For a more thorough discussion of the "representational model", see Chapter 2.

${ }^{42}$ This latter factor is examined in Chapter 4.
} 
examine recent research on federal judicial sentencing and explain how the present model builds and improves upon said research. Fourth, I set forth testable hypotheses derived both from my theoretical perspective and important prior findings. Fifth, I construct a model to empirically test these hypotheses. Finally, I examine the results of the model and discuss the results.

\section{Location and District Court Behavior}

Many early researchers of judicial behavior sought to examine the influence of contextual factors on district court decision-making. As set forth in the prior chapters, several scholars have found a link between local communities and the behavior of federal judges (Peltason 1971; Vines 1964; Cook 1973, 1971; Kritzer 1978; Kuklinski and Stanka 1979; Rowland and Carp 1996). ${ }^{43}$ While these studies provide some preliminary support for community-based influence on appellate behavior, empirical testing of public influence on unelected appellate judges has also produced several null or highly conditional results. (Brace and Boyea 2008; Segal and Spaeth 2002; Mishler and Sheehan 1996).

To reconcile the foregoing findings, I argue that trial judges, as opposed to appellate judges, are fundamentally more likely to be responsive to local contextual factors. First, trial judges deal directly with people in their community on a daily basis. Whether it is civil litigants, criminal defendants, or jurors, federal district court judges are directly exposed to many different members of their district that appellate judges simply are not. This fact alone could make these trial judges more sensitive to environmental factors than their appellate brethren. Moreover, trial judges are less driven by their personal ideological orientation than judges at higher levels of the judiciary (Posner 1993; Epstein, et. al. 2013). Thus, it is plausible that if judges' personal ideologies are less influential, then other factors, either case-specific or environmental, have greater import.

\footnotetext{
${ }^{43}$ For a more thorough discussion of these pieces of research, please see Chapter 1.
} 
The idea that trial judges are fundamentally different than appellate judges is certainly not a novel argument. One federal Court of Appeals judge compared the difference between trial judges and appellate judges to watching Gone with the Wind vs. reading a TV Guide description of the film (Batchelder 1993). Goldman and Sarat (1978) point to several differences between trial court judges and appellate court judges, including direct interaction with litigants. Baum (1994) argues that since district court judges live in their district, they may be particularly sensitive to environmental factors, because their rulings may affect judges' standings among their friends and associates in the district.

Aside from trial/appellate judge differences, there is also some recent indirect evidence that public opinion is influential on criminal justice policy generally. Nicholson-Crotty, et. al. (2009) find that, over time, federal criminal justice policy is responsive to a dimension of public mood. Enns (2014) similarly finds increasing public punitiveness is a contributing factor to the rising incarceration rate over the past approximately fifty years. While these studies were conducted on a national level and do not isolate only judicial behavior, the results intimate the influence public sentiment, whether local or national, may have on unelected criminal justice decision makers.

In summary, while the results regarding contextual influences on federal district court judges is somewhat mixed, there is certainly sufficient anecdotal and empirical support to warrant further study. Federal district court judges are often long-time residents of their districts (Silver and Shapiro 1984). They also directly interact with citizens and observe first-hand certain social and political characteristics of their community through their work on the bench. Thus, it would be surprising indeed to find that sociopolitical factors do not affect district judge decision-making. 


\section{Sentencing in Federal Courts}

Prior to discussing specific studies on federal sentencing, it is necessary to understand the historical background of modern federal sentencing practice. For the purposes of this chapter, it is necessary to understand that there are different "eras" of judicial sentencing under the sentencing Guidelines. The different legal rules and/or standards associated with each era are set forth below: ${ }^{44}$

\section{[Figure 1 about here]}

To summarize, the amount of discretion that district court judges have enjoyed in their sentencing practices has varied over time. There is little doubt that judges in recent years have enjoyed the greatest amount of discretion in their sentencing decisions. By 2014, more than half of offenders were sentenced below the range recommended by the Guidelines. The Sentencing Commission and several recent researchers of sentencing under the Guidelines have analyzed this trend in depth and noted the strong effect that policy consequences, such as the PROTECT Act and Booker, had on district court sentencing practices (Fischman and Schanzenbach 2011; Epstein, et. al. 2013; USSC 2012). More specifically, this research, as well as the raw data, provides strong evidence that district judges are more willing to make departures from Guideline recommended ranges in recent years, which have been characterized by greater judicial discretion.

The focus of this chapter however, is not simply to analyze how these national-level policy changes to discretion have affected judges, but instead to examine inter-district differences within the country. These differences can be substantial. For example, in FY 2014, the Eastern District of Wisconsin sentenced only $20.6 \%$ of offenders to a sentence within the recommended Guideline Range, while the Southern District of Mississippi sentenced 67.2\% of

\footnotetext{
${ }^{44}$ For a more detailed background on federal sentencing over time, please see Chapters 1 and 2 of this dissertation.
} 
offenders within the recommended range (USSC 1995-2014). It is worth reiterating that state and local sociopolitical conditions are certainly not expected to be the sole explanation for this disparity, as differing prosecutorial practices (Lynch and Omori 2014; Wu and Spohn 2010; Bibas 2005), as well as crimes committed (USSC 2012), are also contributing factors. Still, the size of the disparity is further indication that district judges in different parts of the country may have vastly different views regarding criminal sentencing.

Before proceeding with a discussion of prior scholarship on federal sentencing, two additional facts regarding judicial discretion and federal sentencing practice merit brief discussion. First, a substantial proportion of offenders, especially drug offenders, are subject to mandatory minimum sentences. In these cases, judges are not permitted to depart from the Guidelines. The increased use of mandatory minimum sentences in recent years has had the effect of mitigating any judicial departures on average imprisonment length (USSC 2012).

Second, an important distinction should be made between Guideline departures that are sponsored by the government and Guideline departures that are not sponsored by the government. The most utilized of government sponsored departures are known as $5 \mathrm{~K} 1.1$ "substantial assistance" departures, wherein the government or prosecution moves the Court to grant the offender a below-range sentence based upon his/her assistance in the prosecution of another individual. Essentially, substantial assistance departures give offenders or potential offenders an incentive to give the government valuable information regarding more serious criminals. While the use of substantial assistance departures has declined over time, coinciding with increased levels of judicial discretion allowing judges to depart on their own, it is still a relatively prevalent policy, occurring in 12.8\% of cases in FY 2014. 
The prevalence of both mandatory minimum sentencing and substantial assistance Guideline departures are key background facts necessary to understanding federal sentencing practice. Like departures themselves, there is great inter-district variation in the prevalence that these two methods are employed throughout the country. To the extent this variation may have an impact on disparity in sentence length or judicial departures, both factors must be accounted for.

\section{Past Federal Judge Sentencing Research}

Some of the earliest research on federal district court sentencing addressed the question of whether district court judges were sensitive to contextual influences, such as public sentiment (Cook 1973, 1977; Kritzer 1978; Silver and Shapiro 1984). While the findings of these scholars showed evidence of community-based influences on federal district court judges, more recent research on federal sentencing has focused on different variables. Specifically, recent scholarship on district judge behavior under the US Sentencing Guidelines has primarily focused on whether or not changes in policy have affected judge's adherence to the Guidelines.

Fischman and Schanzenbach (2011) find the 2003 PROTECT Act provisions that allowed appellate courts to review district court judge departures from the Guidelines without giving any deference to the district court judge, increased district judge adherence to the Guidelines. Similarly, in a recent study, Epstein, et. al. (2013) found the rate of departures from the Guidelines has increased substantially in the post-Booker era. Both Fischman and Schanzenbach (2011) and Epstein, et. al. (2013) also detected strategic and partisan influences on sentencing behavior, as both found that as the number of Republican judges on the Court of Appeals sitting above the district court judge increased, the less likely the sentencing district judge was to depart from the Guidelines. 
While a great bulk of the research on federal sentencing has focused on the effect of nationwide policy change in discretion, recent research has examined the causes and consequences of sentencing disparity among similarly situated offenders throughout the country. The Sentencing Commission has attributed increased disparity to the increased discretion that resulted from the post-Booker Era (USSC 2012). But Tiede (2009) finds that whether or not Booker increased or decreased disparity varied greatly based on region of the country. Ulmer, et. al. (2011) and Lynch and Omori (2014) also question the Sentencing Commission's conclusions regarding the effect of Booker and argue that increased disparity after Booker has much to do with adapted prosecutorial practice.

Specific causes of the sources of inter-district sentencing variation has also been examined, if less thoroughly. Kautt (2002) attributes much of inter-district variation in sentencing practice to local legal culture. Wu and Spohn (2010) find differences in the prevalence of "substantial assistance" tactics by prosecutors can result in sentencing inequities between districts. Ulmer (2005) examines variation in Sentencing Practices and finds that differing interpretations of Guideline terms and parlance can lead to disparate outcomes. In their analysis of federal drug trafficking cases, Lynch and Omori (2014) find the use of mandatory minimum sentencing greatly impacted sentencing disparity between districts. Of particular relevance, Lynch and Omori found there was much greater variation in average drug trafficking sentence length between districts than within districts $(2014,430)$.

Still, most of these studies do not address "political environment" factors emphasized by earlier researchers, such as Cook (1971) and Kritzer (1978). Johnson, et. al.'s (2008) study represents an important exception, as these researchers specifically examined the extent to which certain environmental effects, such as crime rates, caseload pressures, and the liberalness of 
districts affected sentence length. Johnson, et. al. (2008) find little relationship between the crime rate and judicial behavior. ${ }^{45}$ However, they do find that districts with higher levels of liberalism, measured by interest group ratings of the US Senators of the applicable state, exhibit more lenient sentencing practices.

There are several reasons why the findings of Johnson, et. al. (2008) should be subjected to further empirical analysis. All of these reasons relate to the relatively narrow time period covered by Johnson, et. al. (2008), namely FY 1997-2000. First, as a result of this window, it is difficult to draw conclusions about how changes in sociopolitical variables within the same district may alter judicial behavior over time. As discussed throughout this dissertation, this dynamic analysis is particularly useful in drawing causal conclusions, and many variables of interest (departure rates, the crime rate, and liberalness) have all varied substantially within districts over time. Secondly, as all of the cases analyzed by Johnson, et. al. (2008) are prior to either the enactment of the PROTECT Act (which reduced judicial discretion) or the Booker decision (which expanded judicial discretion), we are unable to draw conclusions about how different judges in different areas of the country respond to different periods of judicial discretion. Yet the findings of Fischman and Schanzenbach (2011) and Epstein, et. al. (2013) suggest these policy changes dramatically altered sentencing practice, and the findings of Tiede (2009) suggest judges in different areas of the country may respond quite differently to increases

\footnotetext{
${ }^{45}$ However, Johnson, et. al. (2008) do find that increases in the crime rate result in increased the length of substantial assistance departures. They interpret this result as possible evidence of judges working with prosecutors to address the crime problem by allowing departures for less serious offenders while aiding the prosecution of more serious offenders.
} 
or decreases in their discretion. Accordingly, a renewed focus on sociopolitical factors

incorporating these differing levels of discretion over time is worthwhile. ${ }^{46}$

In summary, the findings of Kautt (2002), Wu and Spohn (2010), Ulmer (2005), Tiede

(2009), Johnson, et. al. (2008), and Lynch and Omori (2014) all support the same general

conclusion: sentencing in federal district courts depends heavily on the location of the sentencing

district court. Despite this conclusion, with the notable exception of Johnson, et. al. (2008), there

has been less direct research on the question of whether localized sociopolitical factors impact

said localized difference. Given the extent of the variation, and the findings of Johnson, et. al.

(2008) over a limited period of time, further inquiries into these factors is clearly warranted.

\section{Hypotheses}

Given the foregoing I submit two testable hypotheses regarding the influence local contexts may have on district judges' sentencing decisions. The first such hypothesis involves the crime rate. ${ }^{47}$ Specifically:

H1: District judges within states/years with relatively high crime rates will sentence offenders less leniently than district judges in states/years with relatively low crime rates.

The logic of the crime rate Hypothesis is that district judges living and working in environments with high crime will be less sympathetic to criminals. In addition, as judges from higher crime areas will likely see crime as a larger social problem, they will be more likely to

\footnotetext{
${ }^{46}$ It is also worth noting that the measure of state-level political liberalism used by Johnson, et. al. (2008) (US Senator, interest group ratings for the state) has been critiqued and potentially improved upon in recent years (See Enns and Koch 2013).

${ }^{47}$ Ideally, I would also test of the effect of the incarceration rate on interdistrict sentencing variance. However, there is not such variation in the federal incarceration rate, which is reported nationwide. Further, unlike the crime rate, the incarceration rate at the state level is heavily dependent on the state criminal justice system outside exercised completely outside of the jurisdiction of district court judges. Indeed, over $80 \%$ of incarcerated individuals are sentenced through the state-court system rather than the federal court system (DOJ 2015). As a result, it is unlikely that state variability in incarceration rates is internalized by federal judges in any way that would affect their sentencing decisions.
} 
attempt to deter future individuals from committing crimes through longer sentences. ${ }^{48}$ There is some qualified support for H1 as Ulmer and Bradley (2006) found that Pennsylvania judges in counties with higher crime rates tended to render more punitive sentences. Gibson (1980) made a similar finding regarding Iowa judges. Gibson's (1980) findings are especially interesting, because Iowa state judges travel across counties. Thus, Gibson (1980) finds the same judges sentence criminals more severely in areas with higher crime rates. While there might be reasons to think that the Ulmer \& Bradley (2006) and Gibson (1980) results would not hold for unelected federal judges, their findings at least merit the inclusion of the crime-rate variable in models of sentencing behavior.

H2: District judges within states/years with relatively liberal ideologies will sentence offenders more leniently than district judges in states/years with relatively conservative ideologies.

The state ideology hypothesis is consistent with a view of political behavior that judges are reflections of their community (Goldman and Sarat 1978; Rowland and Carp 1996). ${ }^{49}$ It should be noted that while general liberal/conservative ideology is by no means a perfect proxy for treatment towards criminals, there has historically been a strong correlation between conservative ideology and harsher treatment towards criminals (Enns 2014). ${ }^{50}$ Further, H2 will serve as a replication for the finding of Johnson, et. al. (2008) regarding citizen ideology, who found that judges in districts with more liberal ideologies have more lenient sentencing practices. Replication of this finding is prudent, as that study focused on a relatively narrow time period

\footnotetext{
${ }^{48}$ For a more detailed justification for the crime rate hypothesis, see Chapters 2 and 4.

${ }^{49} \mathrm{H} 2$ is not necessarily meant to suggest that public ideology is directly influencing judges to sentence a certain way. While public influence is a possibility, it is also likely that judges within states share the same ideological orientation as citizens of the state (See Segal and Spaeth 2002; Kritzer 1978). Issues of endogenity and causality will be discussed further in the Discussion Section, below.

${ }^{50}$ Although this may be changing. See Act, et. al. (2015) and a further discussion of the possibly weakening relationship between ideology and punitive preferences discussed more thoroughly in Chapters 4-5.
} 
and used a somewhat limited measure of state ideology (Johnson, et. al. 2008). For these

reasons, it is possible that the Johnson, et. al. (2008) model underestimated the influence that state ideology has on federal district court sentencing.

\section{Design, Methods and Measures}

To test the above-stated hypotheses, I employ a panel design, incorporating all available sentencing departure data from ninety (90) federal districts in the US States and the District of Colombia from 1996-2011. ${ }^{51}$ This time period was slightly condensed due to data availability, but the study still encompasses a relatively long time period that spans varying levels of judicial discretion. Rather than focus on a single offense or set of offenses and conduct a micro-analysis (See e.g. Lynch and Omori 2014), the present analysis seeks to present a broad picture of sentencing practice across multiple offenses at the district level.

\section{The Dependent Variable}

To measure the primary dependent variable of interest, harshness/lenience in federal district court sentencing, I use two separate measures: 1) the proportion of all sentences that were downward departures from the Guideline-recommended range in a given district/year ("Total Downward Departures"); and 2) after excluding substantial assistance departures, the proportion of remaining sentences that were judge-initiated downward departures from the Guidelinerecommended range in a given district/year (“Judge-Initiated Downward Departures”).

The basis for using two separate measures of departures is to ensure that the model truly captures judicial behavior. There has been some discussion in the literature as to whether

\footnotetext{
51 Notably, this study differs from several other sentencing studies, as it analyzes sentencing data at the district-level rather than at the individual case level. This approach is not to diminish the importance of well-established casespecific facts, such as the race of the offender (Ulmer, et. al. 2011), the gender of the offender (Mustard 2001), or whether the offender is convicted by trial or plea agreement (Ulmer, et. al. 2010). Instead, as the present study seeks to test only sociopolitical effects, all of such effects should be incorporated into district-level averages. To ensure that sociopolitical factors and case-specific factors are not conflating, I control for offender demographics and plea rates, as explained below.
} 
government-sponsored departures, especially those based on "substantial assistance" to law enforcement, should be included in models of judicial sentencing behavior (See Fischman and Schanzenbach 2011; Freeborn and Hartmann 2010; Schanzenbach and Tiller, 2007). These departures require a motion from the government. As such, they are not solely left to the discretion of the judges. On the other hand, there is some evidence of a negative correlation between substantial assistance departures (the most widely-cited government sponsored departure) and unilateral judicial departures across federal districts (Weinstein 1998). This finding perhaps suggests that judges may be compensating by departing from the Guidelines more often in districts wherein prosecutors file a relatively small number of substantial assistance motions (Weinstein 1998). Furthermore, the judge still has the discretion to grant or deny government-sponsored departure motions. Therefore, both measures of departures are presented as a general robustness check of any findings.

The justification for using Guideline downward departures rates as a measure of judicial punitiveness in general, as opposed to median or mean sentence imprisonment length, is that both laws and the Guidelines themselves change over time (USSC 2012). There also may be changes to the criminal-history and type-of cases prosecuted over time. Measuring Guideline departures best isolates the behavior of the judge. Importantly, this measure of Guideline departures also follows past research studying judicial sentencing behavior (Epstein, et. al., 2013; Fischman and Schanzenbach, 2011, Freeborn and Hartmann, 2010; Schanzenbach and Tiller, $2007) .^{52}$

\section{Independent Variables}

${ }^{52}$ See Chapter 2 for a more thorough discussion of the departure measure, as well as alternative measures. 
To measure the various crime rates, I take the reported violent crime rates for each state in a given year. The state crime rate data comes from the FBI's Uniform Crime Reporting Statistics and is measured as the number of violent crimes in the state per 100,000 citizens.

To measure citizen ideology, I use a recently developed measure calculated by Enns and Koch (2013). The measure is developed by pooling ideological self-identification survey responses from several different surveys by citizens in every state to develop a measure of liberalness in each state of each year. The measure is an improvement upon interest-group ratings measures of state citizen ideology as it is not dependent on congressional behavior and exhibits more year-to-year stability (Enns and Koch 2013). ${ }^{53}$

Two important assumptions should be mentioned at this juncture. First, as discussed in Chapter 2, the state crime rate and state citizen ideology measures are calculated on a calendar year basis, while the sentencing data is presented on a fiscal year basis (October 1-September 30). Thus, for a panel design, the researcher must choose whether to correlate fiscal years and annual years or correlate prior calendar years with subsequent fiscal years. Given that it makes no intuitive sense to ascribe judicial response to factors that have not occurred yet and given that we might expect some unspecified lag in judicial responsiveness, I adopt the latter option (e.g. the state crime rate from January 1, 2012-December 31, 2012 corresponds with total downward departures from October 1, 2012-September 30, 2013). To ensure that these do not produce biased results, I shall also run models matching fiscal year with annual years (e.g. January 1, 2013-December 31, 2013 corresponding with October 1, 2012-September 30, 2013). ${ }^{54}$

Second, it is noteworthy that, in some cases, the level of analysis for the independent variables (measured at the state level) does not match the level of analysis for the dependent

\footnotetext{
${ }^{53}$ For a full discussion of the measure, see Enns and Koch (2013).

${ }^{54}$ See Appendix E
} 
variable (measured at the district level). While twenty six states and the District of Columbia have only one federal district, the remaining twenty four states, generally higher population states, are divided into multiple districts (from two to four). Accordingly, for each multi-district state, I am forced to utilize the statewide data for all districts within that state. Given the localized focus of my theoretical perspective, this is certainly a limitation of my design. However, there are several factors that alleviate this limitation.

First, I will create a control variable for the number of districts within states to ensure that the results are not substantially different from states with single districts. Second, this method of using state-level inputs to measure federal district sentencing behavior has been utilized by recent researchers (Johnson, et. al. 2008). Finally, and most importantly, any bias to the results created by this issue would certainly be in the conservative direction. Stated differently, if localized social and political factors are impacting judges, we would expect using state-level data as opposed to district-level data to weaken, rather than strengthen, any results.

\section{Control Variables}

Several control variables will also be utilized to ensure any results related to the independent variables are not reflective of other district characteristics. The percentage of African American and Hispanic offenders in each district for each year will be incorporated into the model as there is evidence that African Americans and Hispanics are less likely to receive Guideline departures than white offenders (Mustard 2001; Johnson 2003; Ulmer, et. al. 2011). Additionally, the proportion of female offenders will also be included as there is evidence that females are more likely to receive Guideline departures (Mustard 2001). The proportion of four general offense types are also controlled for: drug trafficking offenses, firearm offenses, fraud 
offenses, and immigration offenses ${ }^{55}$, to ensure that differences in departure rates are not simply due to different types of crimes. The size of each district is controlled for by the population and number of judges in each district. There is also great inter-district variability in the caseload perjudge, so this factor is also included in the models.

District-specific prosecutorial practices also need to be accounted for. The percentage of sentences that were reached by plea agreement will be incorporated, as there is a welldocumented sentence "penalty" for offenders convicted after going to trial (Ulmer, et. al. 2011). The proportion of mandatory minimum sentences in the district is also included, as mandatory minimum practice varies widely and its prevalence restricts judge-initiated departures (Lynch and Omori 2014). Furthermore, for the models that exclude substantial assistance departure (“Judge-Initiated Downward Departures"), substantial assistance departure rates will be included as an independent variable.

There are also some districts that are especially unique for historical reasons and/or the type of cases they hear. The five "border districts" with Mexico deal with huge caseload pressures and are faced with a disproportionate share of immigration cases. ${ }^{56}$ As such, these districts are given a dummy variable. Additionally, districts located in Southern States, as defined by the US Census Bureau, are controlled for using a dummy variable, as these districts are associated with higher punitiveness. While it is possible that this variable may capture some of the effects of the "State Citizen Ideology" variable, it is worth examining whether there is

\footnotetext{
${ }^{55}$ Together, these four offenses comprise over $90 \%$ of all federal sentences. Thus, remaining offenses (e.g. kidnapping), will serve as the reference category.

${ }^{56}$ These districts are the Southern District of California, the District of Arizona, the District of New Mexico, the Western District of Texas, and the Southern District of Texas.
} 
some especially unique effect of sentencing behavior in the South, independent of simple conservative ideology.

To account for changes to judicial discretion in making Guideline departures over time, I use dummy variables for the short time period the PROTECT Act was in effect and for the time period Booker was in effect. ${ }^{57}$ This control ensures that any observed effects in the contextual variables of interest are not simply the result of different periods of judicial discretion. Finally, as to the judges themselves, the proportion of judges on the court who were appointed by Democratic Presidents in a given fiscal year is also a control, as we would expect "Democratic" judges to depart downward from the Guidelines more often (Fischman and Schanzenbach, 2011; Epstein, et. al. 2013). ${ }^{58}$ Incorporating this control into the model ensures that inter-district variation in judicial departures is not simply based on the partisan composition of the bench in each district. As each criminal case is randomly assigned a judge within a district, it is reasonable to assume that no individual judges sentence a highly disproportionate share of offenders within their district. For reference, a table with complete descriptions of the measurement of all variables is provided in Appendix A.

\section{Methods}

As set forth above, I employ a panel design with ninety (90) federal districts over the course of sixteen (16) years (1996-2011). To analyze relationships in this panel design, I utilize both a fixed- effect estimator (which control for each individual district) and a random effects estimator (which assumes all pertinent differences between districts are captured by the variables

\footnotetext{
${ }^{57}$ For FY 2003 and 2005, wherein each era of discretion was partially in effect, I take the proportion of cases that each particular policy was in effect and substitute this proportion for the dummy variable.

${ }^{58}$ For a more precise explanation of how this measure accounted for judges commissioned or retired partially through a fiscal year, see Appendix A.
} 
in the model). ${ }^{59}$ Both since my theory is based upon localized factors and because the number of districts (90) is larger than the number of years (16), using only a random-effects model might seem initially attractive. However, the fixed-effects models allow for analysis of the same district over time. This within-case analysis is also of-interest theoretically, as it will allow for drawing inferences regarding whether or not changes to the variables of interest are associated with within-district changes in judges' sentencing behavior. For this reason, both types of models are utilized.

Similar to the national-level data analyzed in Chapter 2, the error structure of a simple linear model of departure rates at the district level is both serially correlated and heteroskedastic. In addition, as is often the case with panel data of states or countries, it is likely improper to assume the cross-sections (districts) are entirely independent from one another. ${ }^{60}$ Thus, to correct for these issues, Driscoll-Kraay standard errors are utilized in both sets of models, wherein the error structure of the model is assumed to be heteroskedastic, serially correlated, and correlated across districts (Driscoll and Kraay 1998). ${ }^{61}$

\footnotetext{
${ }^{59}$ Note that use of a random effects model assumes that any uncaptured differences between cross sections are uncorrelated with the independent variables. The Hausman (1978) test comparing the coefficients of the random effects and fixed effects models, tests this assumption. Results from the Hausman test for the departure series yield a statistic of 20.30 and a $p$ value of .21. Thus, we fail to reject the null hypothesis that the random effects model is valid.

${ }^{60}$ For example, we might expect correlations between districts within the same state, between districts in neighboring states, and between districts with similar demographics.

${ }^{61}$ While use of Driscoll and Kray standard errors can often produce somewhat optimistic standard errors, this procedure is still less optimistic than other methods of estimating standard errors when there is both cross-sectional and temporal correlation (Hoechle 2007). For instance, technically both feasible Generalized Least Squared (GLS) and OLS with panel-corrected standard errors estimates are expected to be imprecise in cross-sectional dominant models (when $N$ is large relative to $T$ ), as in the present case (Hoechle 2007). However, in order to show the robustness of any results, alternative methods were used to examine relationships, including GLS, fixed effects estimators with clustered standard errors, and OLS with panel-corrected standard errors (See Appendices C-D).
} 


\section{Results}

Results from the models are presented in Table 1 below. The four columns represent two fixed effects and two random effects models, for both Total Downward Departure Rates and Judge-Initiated Downward Departure Rates. As can be seen from Table 1, the coefficients for both primary variables of interest are in the expected direction and statistically significant at conventional levels across all four models. In support of the crime rate hypothesis $(\mathrm{H} 1)$, higher crime rates are associated with lower rates of both total downward departures and Judge-Initiated downward departures. Similarly, in support of the state citizen ideology hypothesis $(\mathrm{H} 2)$, districts within states exhibiting relatively liberal ideologies are associated with higher levels of both types of downward departures. The results are fairly robust and hold across several different specifications. $^{62}$

\section{[Table 1 about here]}

The fit for each of the models is reasonable. The fixed-effects models (columns 1 and 3) both explain approximately $62 \%$ of within-district variance over the sixteen year period. As to the random-effects models, the model presented in column 4, which excludes substantial assistance departures, performs better than the specification presented in column 2, as the Root Mean Squared Error is reduced from 10.3 to 8.5. This is not surprising as we would expect the use of substantial assistance departures to be highly dependent on idiosyncratic differences in the policies/strategies of various U.S. Attorneys throughout the country. Therefore it makes some sense that the variables in the model more successfully explain judge-initiated departures than total departures.

\footnotetext{
${ }^{62}$ See Appendices C-F for alternative specifications.
} 
Turning again to the sociopolitical variables of interest, the effect-sizes for the state liberalism variable are comparatively larger for the random-effects models than the fixed-effects models. This finding is expected as the fixed-effects models are essentially analyses of intradistrict differences over time. Accordingly, we would expect greater inter-district differences in state ideology throughout the country than changes in citizen ideology within a single district over a limited time period. Despite this decreased magnitude, the fact that the state liberalism variable retains significance in the fixed-effect models is of particular interest. Specifically, this result demonstrates that not all causes of sentencing-variation are due to district-specific prosecutorial practices or other district-specific idiosyncrasies (See Lynch and Omori 2014; Bibi 2005). Columns 1 and 3 in Table 1 provide evidence that increasing liberalness [conservativeness] of a state over time is associated with higher [lower] rates of downward departures in districts within that state.

As to the crime rate, the state crime rate coefficient is highly significant across all models. As an additional robustness check, year-specific dummies were also added in separate models to ensure that the state crime-rate findings were not solely the product of the general decreasing crime rate over time matching spuriously with the increasing departure rate over time. Even after utilizing the year-specific dummies, the state crime rate variable remains significant across all four models, although the magnitude of the effect is weakened. (See Appendix F).

Despite the general robustness and high significance-levels of the variables of interest, the effect sizes for both variables are relatively small. Based upon the model in column 4, the best fitting fixed-effect model, a one standard deviation change in the crime rate is expected to alter departure rates by $2.8 \%$. A one standard deviation change in state citizen ideology is 
expected to alter downward departure rates by $1.7 \%$. While these are by no means large effectsizes, they can have enormous practical consequences for convicted offenders.

Figure 2, below, provides a graphic example of the effect-sizes of fixed-effect judgeinitiated departure rates (column 4). Specifically, the left side of Figure 2 compares expected levels of judge-initiated departure rates based upon two hypothetical district/years with high vs low crime rates, with all other variables held at their means. Similarly, the right side of Figure 2 demonstrates the same comparison, but instead compares a relatively conservative hypothetical district/year with a relatively liberal hypothetical district/year. In Figure 2, "Q1" and "Q3" of both input variables are used as proxies for relatively high/low state crime rates or liberal district years.

\section{[Figure 2 about here]}

As can be seen from Figure 2, a district in a year with relatively high crime is expected to have an overall downward departure rate of approximately $18.9 \%$, while the same district in a relatively low-crime year is expected to have a downward departure rate approximately $22.1 \%$ of the time. Stated differently, the odds of an offender receiving a downward departure decrease by about $15 \%$ when a given district changes from having relatively low crime to having relatively high crime, holding all other variables constant. The effects for state-citizen ideology are slightly more muted, but a hypothetical district shift from being relatively conservative to relatively liberal increases a convicted offender's downward departure odds by $10 \%$, holding other variables constant These estimations are meant to be exemplary only, but they present a more intuitive picture of the degree to which sociopolitical variables can potentially influence downward departure rates. 
Aside from the primary variables of interest, there are other interesting takeaways from the results presented in the four models of Table 1. First, the results in columns 1 and 2, which include all downward departures, are extremely similar to the results in columns 3 and 4, which include only judge- initiated downward departures. Aside from some interesting findings regarding prosecutorial practice discussed below, the inclusion or exclusion of substantial assistance cases does not seem to alter the results substantially.

In addition, results from Table 1 replicate many prior findings of past researchers of federal sentencing data. The PROTECT Act period of limited judicial discretion is associated with lower rates of downward departures (Fischman and Schanzenbach, 2011; Freeborn and Hartmann 2010; Tiede 2009), while the Booker period of expanded judicial discretion is associated with higher rates of downward departures (Epstein, et. al. 2013; Tiede 2009). Southern Districts are associated with much lower rates of downward departures (Lynch and Omori 2014). Border Districts, due to a high proportion of immigration cases and the ability to use "fast track" departures unavailable in other districts, are associated with much higher rates of departure (USSC 2012; Fischman and Schanzenbach 2011). Districts with a greater proportion of Democratic judges are significantly associated with higher rates of downward departures in three of the four specifications presented in Table 1 (Fischman and Schanzenbach 2011).

Finally, two results support recent findings in the literature regarding prosecutorial practice. The negative and significant coefficients for "\% mandatory minimum" in columns 3 and 4 support the Lynch and Omori (2014) conclusion that districts with high rates of mandatory minimum sentences restrict judicial departures. The negative and significant coefficients for " $\%$ substantial assistance" support the Weinstein (1998) conclusion that judges in districts that do not utilize substantial assistance will compensate by initiating departures themselves more often. 
Taken together, these findings support recent findings that prosecutorial practices are influential on judge-initiated departure rates.

\section{Discussion, Limitations, and Implications}

This chapter sought to build and improve upon recent research in federal sentencing to account for contextual sociopolitical factors. Specifically, the present design examined the potential effects state citizen ideology and state crime rates had on district judge sentencing decisions. After conducting the test, there is fairly strong support for the argument that these two factors are indeed associated with federal district court judge sentencing decisions. More specifically, the results provide broad support for both H1, predicting a negative relationship between crime rates and lenient sentences, and $\mathrm{H} 2$, predicting a positive relationship between liberal citizen ideology and lenient sentences.

Despite the foregoing, the present study has some clear limitations. First, there is the issue of matching state-level inputs with district-level sentencing data. As explained above, to the extent this issue is problematic, the problem should weaken the foregoing results rather than strengthen them. However, there is no question that a more precise model would utilize districtspecific sociopolitical variables. Future designs may attempt to obtain measures, perhaps through county-level crime rate data or voting data from state legislative or congressional districts.

A further limitation of the model, due to the district level of analysis, is the inability to determine under what conditions judges pay heed to broader social factors. It is obviously extremely unlikely that all district judges are influenced by these contextual factors to the same degree in all types of cases. Indeed, it is possible that certain district judges consider community conditions as a vital component of their general sentencing philosophy, while other 
judges strongly believe these conditions should play no role in determining appropriate sentences for individual offenders. Future research should attempt to conduct case-studies or gather judgespecific data to determine if only particular judges are sensitive to these broader societal inputs.

Limitations aside, the present research provides support for at least five propositions that build and improve upon present understandings of sentencing practice and federal district court behavior. First, there is fairly strong evidence that some federal district court judges incorporate contextual factors into their sentencing decisions. This general finding serves as a basis to replicate these findings using different models and methods and incorporating different contextual variables. For example, future research designs could examine the potential effect of local legal community sentiment or incarceration rates on sentencing practice.

Second, the "representational model" of judicial behavior should be reevaluated and retested in both the sentencing context and in other contexts (See Silver and Shapiro 1984). This research provides evidence that district court departure rates are associated with the citizen ideology of the state the district lies in. I stop short of arguing that judges are responsive to citizen ideology. As argued by Kritzer (1978), Segal and Spaeth (2002), and other scholars of the effect public opinion may have on the judiciary, judges are members of the public, not necessarily agents of the public. The observed correlation between state citizen ideology and judicial behavior may simply be due to the fact that federal district court judges themselves are citizens of their states.

Despite this possibility, there is some theoretical basis to suspect trial judges may be responsive to what the public thinks/believes. Trial judges, unlike appellate judges, have everyday dealings with citizens whose views may directly or indirectly enter their courtrooms. Moreover, recent research indicates that criminal justice policy in general is responsive to citizen 
punitive attitudes (Nicholson-Crotty, et. al. 2009; Enns 2014). Future designs, perhaps modeled after the elected-official responsiveness literature (See Edwards and Wood 1999), should attempt to sort out this causal issue and further examine whether judges are responding to the public or moving in-step with them.

Third, the potential effect of crime rates on sentencing practice should be further scrutinized. This study's findings with respect to the crime rate are particularly intriguing. The effect of the state crime rate was highly significant, even when controlling for other factors such as plea rates and differing periods of judicial discretion. These findings support state-court analyses, such as Gibson (1980) and Ulmer and Bradley (2006) but are somewhat contrary to the findings of Johnson, et. al.(2008) regarding federal district court judges. Johnson, et. al. (2008) found little impact of higher crime rates, and their sole significant conclusion was that higher crime rates were associated with longer substantial assistance departures. The fact that the findings herein do not square with Johnson, et. al. (2008) is possibly the result of the more restrictive time period of the Johnson, et. al. (2008) design. More specifically, it may be that increased levels of judicial discretion in recent years not covered by the Johnson, et. al. (2008) study have allowed judges to better account for sociopolitical factors, such as the crime rate. ${ }^{63}$ In any case, the crime rate variable should be retested using different research designs to determine if it is in fact impacting judicial sentencing decisions

Fourth, this research supports but modifies recent findings emphasizing the differences of federal judges based upon location (Lynch and Omori 2014; Tiede 2009; Kautt 2002). As stated by one recent scholar "while the districts that make up the federal system operate under the same formal law, the system as a whole should not be treated as a single, unified entity that responds

\footnotetext{
${ }^{63}$ But See Ulmer, et. al. (2011) concluding that increased levels of judicial discretion are not associated with increased inter-district disparity.
} 
lockstep to policy mandates" (Lynch and Omori 2014, 438). This research underscores this sentiment, but adds a temporal element. Not only does place matter, but time matters also. The fixed-effects models provide strong evidence that changing conditions within districts can alter the behavior of judges. Whether these changes in behavior are a result of turnover within districts or adapting behavior of the same judges should be subjected to empirical testing.

Finally, the evidence of the effects of two state-level variables on judges in the criminal sentencing context should lead researchers to test contextual effects on judges in other contexts and policy areas. For example, does income inequality make it more likely that district court judges would render summary judgment against wealthy litigants? Do natural disasters in districts cause judges to be less favorable to insurance litigants in their rulings? The list of potential inquiries is long, and the answers to said inquires could provide a much better understanding of both judicial behavior and the justice system generally.

\section{References}

Act, Justice, Richard Vigueire, David Keene, Pat Nolan, and Grover G. Norquist. 2015. "Conservative Letters in Support of SAFE Justice Act of 2015." Federal Sentencing Reporter 28(2):135

Bartels, Larry. 1991. “Constituency Opinion and Congressional Policy Making: The Reagan Defense Buildup.” American Political Science Review, 85(2):457-474.

Batchelder, Alice M. 1993. “Some Brief Reflections of a Circuit Judge.” Ohio State Law Journal. 54(5):14531462.

Baum, Lawrence. 1994. "What Judges Want: Judges' Goals and Judicial Behavior.” Political Research Quarterly. 47(3):749-768.

Baum, Lawrence. 1997. The Puzzle of Judicial Behavior. Ann Arbor: University of Michigan Press.

Baum, Lawrence. 2006. Judges and Their Audiences. Princeton, NJ: Princeton University Press.

Bibas, Stephanos. 2005. "Federalism: Regulating Local Variations in Federal Sentencing," Stanford Law Review 58:137.

Clinton, Joshua D. 2006. "Representation in Congress: constituents and roll calls in the $106^{\text {th }}$ House. Journal of Politics 68 (2):397-409.

Cook, Beverly B. 1977. "Public Opinion and Federal Judicial Policy." American Journal of Political Science 21: 567-600. 
Cook, Beverly B. 1973. "Sentencing Behavior of Federal Judges: Draft Cases, 1972.” Cincinnati Law Review 42:597-633.

Driscoll, John., and Art C. Kraay. 1998. "Consistent Covariance Matrix Estimation with Spatially Dependent Data. Review of Economics and Statistics 80: 549-560.

Edwards, George C. III and B. Dan Wood. 1999. "Who Influences Whom? The President, Congress, and the Media. American Political Science Review. 93(2): 327-344.

Enns, Peter. 2014. "The Public's Increasing Punitiveness and Its Influence on Mass Incarceration in the United States" The American Journal of Political Science. 58(4): 857-872.

Enns, Peter and Julianna Koch. 2013. "Public Opinion in the U.S. States: 1956-2010”) State Politics and Policy Quarterly. 13(3): 349-372.

Epstein, Lee, William M. Landes, \& Richard A. Posner. 2013. The Behavior of Federal Judges. Cambridge, MA: Harvard University Press.

Fiorina, Morris P. 1974. Representationals, Roll Calls, and Constituencies. Lexington Books.

Fischman, Joshua B. \& Max Schanzenbach. 2011 "Do Standards of Review Matter? The Case of Federal Criminal Sentencing." Journal of Legal Studies 40:405-437.

Freeborn, Beth A., and Monica E. Hartmann. 2010. "Judicial Discretion and Sentencing Behavior: Did the Feeney Amendment Rein In District Judges?” Journal of Empirical Legal Studies 7:355-378.

Gibson, James L. 1980. "Environmental Constraints on the Behavior of Judges: A Representational Model of Judicial Decision Making. Law \& Society Review 14:343-370.

Hausman, Jerry A. 1978. "Specification Tests in Econometrics.” Econometrica 46: 1251-1271.

Hoechle, Daniel. 2007. "Robust Standard Errors for Panel Regressions with Cross-Sectional Dependence." The Stata Journal 7 (3): 281-312.

Jacobson, Gary. 2012. “The Electoral Origins of Polarized Politics.” American Behavioral Scientist 56(12):16121630 .

Johnson, Brian. 2003. Racial and Ethnic Disparities in Sentencing Departures Across Modes of Conviction. Criminology 41:449-88.

Johnson, Brian, Jeffery T. Ulmer, and John H. Kramer. 2008. “The Social Context of Guidelines Circumvention: The Case of Federal District Courts." Criminology 46(3):737-783

Kautt, Paula (2002) "Location, Location, Location: Interdistrict and Intercircuit Variation in Sentencing Outcomes for Federal Drug-Trafficking Offenses," Justice Quarterly 19:633-71.

Kritzer, Herbert. 1978. "Political Correlates of the Behavior of Federal District Judges: A Best Case Analysis." Journal of Politics 40:25-58.

Kuklinski, James H. and John E. Stanga. 1979. "Political Participation and Government Responsiveness: The Behavior of California Superior Courts." American Political Science Review 73:1090-1099.

Lynch, Mona and Marisa Omori. 2014. "Legal Change and Sentencing Norms in the Wake of Booker: The Impact of Time and Place on Drug Trafficking Cases in Federal Court." Law and Society Review 48 (2):411-445.

Mayhew, David R. 1974. Congress: The Electoral Connection. Yale University Press. 
Miller, Warren E., and Donald E. Stokes. 1963. "Constituency influence in Congress." American Political Science Review 57(1): 45-56.

Nicholson-Crotty, Sean, David A.M. Peterson, and Mark D. Ramirez. 2009. "Dynamic Representation(s): Federal Criminal Justice Policy and an Alternative Dimension of Public Mood." Political Behavior 31(4):629-655.

Peltason, Jack AW. 1971. Fifty-Eight Lonely Men: Southern Federal Judges and School Desegregation. Urbana, IL: University of Illinois Press.

Posner, Richard A. 1993. "What do Judges and Justices Maximize? (The Same Thing Everybody Else Does." Supreme Court Economic Review 3:1-41.

Rowland, C.K. \& Robert A. Carp. 1996. Politics and Judgment in Federal District Courts. Lawrence, KS: University of Kansas Press.

Schanzenbach, Max M., and Emerson H. Tiller. 2007. "Strategic Judging under the U.S. Sentencing Guidelines: Positive Political Theory and Evidence." Journal of Law, Economics, and Organization 23:24-56.

Segal, Jefferey A. and Harold J. Spaeth. 2002. The Supreme Court and the Attitudinal Model Revisited. New York: Cambridge University Press.

Stith, Kate \& Jose A. Cabranes. 1998. Fear of Judging: Sentencing Guidelines in the Federal Courts. Chicago, Il: University of Chicago Press.

Tiede, Lydia B. 2009. The Impact of the Federal Sentencing Guidelines and Reform: A Comparative Analysis. The Justice System Journal 30(1):34-49.

Ulmer, Jeffery T. 2005. "The Localized Uses of Federal Sentencing Guidelines in Four U.S. District Courts: Evidence of Processual Order," Symbolic Interaction 28:255.

Ulmer, Jeffery T. \& Mindy S. Bradley. 2006. "Variation in Trial Penalties Among Serious Violent Offenses." Criminology 44:631-670.

Ulmer, Jeffery T., \& Brian Johnson, B. 2004. Sentencing In Context: A Multilevel Analysis. Criminology 42: 137178.

Ulmer, Jeffery T, Michael T. Light, and John H. Kramer. 2011. "The "Liberation” of Federal Judges' Discretion in the Wake of the Booker/ Fanfan Decision: Is There Increased Disparity and Divergence Between Courts?," Justice Quarterly 28:799-837.

United States Department of Justice. 2015. "Prisoners in 2014." Accessible at http://www.bjs.gov/content/pub/pdf/p14.pdf

United States Sentencing Commission. 1995-2014. Sourcebook of Federal Sentencing Statistics. Accessible at: http://www.ussc.gov/Research_and_Statistics/Annual_Reports_and_Sourcebooks/Archives.cfm

United States Sentencing Commission. 2006. Final Report of the Impact of United States v. Booker on Federal Sentencing. Washington, D.C.: United States Sentencing Commission.

United States Sentencing Commission. 2012. Report on Continuing Impact of United States v. Booker on Federal Sentencing. Washington, D.C.: United States Sentencing Commission.

Vines, Kenneth. 1964. "Federal District Judges and Race Relations Cases in the South.” Journal of Politics 26:337-357. 
Weinstein, Ian. 1998. "Substantial Assistance and Sentence Severity: Is There a Correlation Substantial Assistance." Federal Sentencing Reporter Rep 11: 83-85.

Wu, Jawjeong \& Cassia Spohn. 2010. Interdistrict Disparity in Sentencing in Three U.S. District Courts." Crime and Delinquency 56: 290-322. 
Figure 1: Periods of Judicial Discretion under the Federal Sentencing Guidelines

\begin{tabular}{|c|c|c|c|c|c|c|}
\hline $\begin{array}{l}\text { Uncertainty } \\
\text { Period } \\
\text { November 1, 1987- } \\
\text { June 12, 1996: } \\
\text {-Uncertainty as to } \\
\text { the Mandatory } \\
\text { Nature of the } \\
\text { Guidelines and the } \\
\text { Standard of } \\
\text { Appellate Review } \\
\text {-Guideline } \\
\text { Departure Rates } \\
\text { Relatively Low }\end{array}$ & $\rightarrow$ & $\begin{array}{l}\text { Increasing } \\
\text { Discretion } \\
\text { June 13, 1996-April } \\
\text { 29, 2003: } \\
\text {-District Court } \\
\text { Judges able to } \\
\text { Depart from } \\
\text { Guidelines under } \\
\text { an "Abuse of } \\
\text { Discretion" } \\
\text { Standard. } \\
\text {-Guideline } \\
\text { Departure Rates } \\
\text { Increase }\end{array}$ & $\rightarrow$ & $\begin{array}{l}\text { Reduced } \\
\text { Discretion } \\
\text { April 30, 2013- } \\
\text { January 12, 2005: } \\
\text {-District Court } \\
\text { Judges given no } \\
\text { Deference on } \\
\text { Appellate Review } \\
\text { - List of Bases for } \\
\text { Guideline } \\
\text { Departure is } \\
\text { restricted } \\
\text {-Guideline } \\
\text { Departure Rates } \\
\text { decrease }\end{array}$ & $\rightarrow$ & $\begin{array}{l}\text { Most } \\
\text { Discretion } \\
\text { January 12, 2005- } \\
\text { Present: } \\
\text {-Sentencing } \\
\text { Guidelines } \\
\text { Rendered } \\
\text { “Advisory” to } \\
\text { District Court } \\
\text { Judges } \\
\text { - "Abuse of } \\
\text { Discretion” } \\
\text { Standard of } \\
\text { Appellate } \\
\text { Review Restored } \\
\\
\text {-Guideline } \\
\text { Departure Rates } \\
\text { increase } \\
\text { substantially }\end{array}$ \\
\hline
\end{tabular}


Table 1: Fixed and Random Effect Determinants of District Total Downward Departure $\%$ and Judge-Initiated Downward Departure \% in 90 districts (FY 1996-2011)

\begin{tabular}{|c|c|c|c|c|}
\hline Variable & $\begin{array}{l}\text { Total } \\
\text { Downward } \\
\text { Departure \% } \\
\text { (Fixed Effect) } \\
\text { (1) }\end{array}$ & $\begin{array}{l}\text { Total } \\
\text { Downward } \\
\text { Departure \% } \\
\text { (Random Effects) } \\
\text { (2) }\end{array}$ & $\begin{array}{l}\text { Judge-Initiated } \\
\text { Downward } \\
\text { Departure \% } \\
\text { (Fixed Effects) } \\
\text { (3) }\end{array}$ & $\begin{array}{l}\text { Judge-Initiated } \\
\text { Downward } \\
\text { Departure \% } \\
\text { (Random Effects) } \\
\text { (4) }\end{array}$ \\
\hline State Crime Rate & $\begin{array}{l}-.011 * * * \\
(.002)\end{array}$ & $\begin{array}{l}-.007 * * * \\
(.001)\end{array}$ & $\begin{array}{l}-.010 * * * \\
(.002)\end{array}$ & $\begin{array}{l}-.005 * * * \\
(.001)\end{array}$ \\
\hline State Liberalism & $\begin{array}{l}.20 * \\
(.09)\end{array}$ & $\begin{array}{l}.52 * * * \\
(.06)\end{array}$ & $\begin{array}{l}.32 * \\
(.17)\end{array}$ & $\begin{array}{l}.41 * * * \\
(.08)\end{array}$ \\
\hline Booker & $\begin{array}{l}9.18 * * * \\
(2.56)\end{array}$ & $\begin{array}{l}6.59 * * * \\
(0.15)\end{array}$ & $\begin{array}{l}13.21 * * * \\
(3.06)\end{array}$ & $\begin{array}{l}13.18 * * * \\
(2.34)\end{array}$ \\
\hline PROTECT Act & $\begin{array}{l}-5.04 * * * \\
(1.22)\end{array}$ & $\begin{array}{l}-7.76^{* * * *} \\
(1.61)\end{array}$ & $\begin{array}{l}-6.07 * * * \\
(1.78)\end{array}$ & $\begin{array}{l}-6.80 * * * \\
(1.75)\end{array}$ \\
\hline $\begin{array}{l}\text { \% Democrat } \\
\text { Judges }\end{array}$ & $\begin{array}{l}.06 * * * \\
(.01)\end{array}$ & $\begin{array}{l}.00 \\
(.05)\end{array}$ & $\begin{array}{l}.07 * * * \\
(.01)\end{array}$ & $\begin{array}{l}.04 * * \\
(.01)\end{array}$ \\
\hline $\begin{array}{l}\text { \# of Districts } \\
\text { In State }\end{array}$ & - & $\begin{array}{l}1.76^{* * * *} \\
(.35)\end{array}$ & - & $\begin{array}{l}.81 * \\
(.39)\end{array}$ \\
\hline \# of Judges in District & $\begin{array}{l}-.43 \\
(-0.66)\end{array}$ & $\begin{array}{l}.19 * * \\
(.07)\end{array}$ & $\begin{array}{l}-.70 \\
(.41)\end{array}$ & $\begin{array}{l}.09 \\
(.08)\end{array}$ \\
\hline $\begin{array}{l}\% \text { African-American } \\
\text { Offenders }\end{array}$ & $\begin{array}{l}-.07 * * \\
(.03)\end{array}$ & $\begin{array}{l}.03 \\
(.03)\end{array}$ & $\begin{array}{l}-.04 * \\
(.03)\end{array}$ & $\begin{array}{l}-.003 \\
(.02)\end{array}$ \\
\hline $\begin{array}{l}\% \text { Hispanic } \\
\text { Offenders }\end{array}$ & $\begin{array}{l}-.12 * * \\
(.05)\end{array}$ & $\begin{array}{l}-.05 * \\
(.03)\end{array}$ & $\begin{array}{l}-.05 \\
(.06)\end{array}$ & $\begin{array}{l}.04 \\
(.04)\end{array}$ \\
\hline$\%$ Firearm & $\begin{array}{l}-.27 * * * \\
(.08)\end{array}$ & $\begin{array}{l}-.13 * \\
(.08)\end{array}$ & $\begin{array}{l}-.21 * * \\
(.08)\end{array}$ & $\begin{array}{l}-.24 * * * \\
(.04)\end{array}$ \\
\hline$\%$ Plea & $\begin{array}{l}.47 * * \\
(.18)\end{array}$ & $\begin{array}{l}.58 * * * \\
(.16)\end{array}$ & $\begin{array}{l}.21 \\
(.17)\end{array}$ & $\begin{array}{l}.18 \\
(.21)\end{array}$ \\
\hline $\begin{array}{l}\text { \% Mandatory } \\
\text { Minimum }\end{array}$ & $\begin{array}{l}-.07 \\
(.16)\end{array}$ & $\begin{array}{l}-.04 \\
(.12)\end{array}$ & $\begin{array}{l}-.25^{*} \\
(.15)\end{array}$ & $\begin{array}{l}-.33 * * * \\
(.09)\end{array}$ \\
\hline $\begin{array}{l}\% \text { Substantial } \\
\text { Assistance }\end{array}$ & - & - & $\begin{array}{l}.01 \\
(.02)\end{array}$ & $\begin{array}{l}-.07 * * \\
(-.03)\end{array}$ \\
\hline Caseload & $\begin{array}{l}.015 \\
(.010)\end{array}$ & $\begin{array}{l}.010 \\
(.011)\end{array}$ & $\begin{array}{l}.01 \\
(.01)\end{array}$ & $\begin{array}{l}-.001 \\
(.008)\end{array}$ \\
\hline $\begin{array}{l}\% \text { Above } \\
\text { Median Sentence }\end{array}$ & $\begin{array}{l}.28 * \\
(.14)\end{array}$ & $\begin{array}{l}.22 \\
(.15)\end{array}$ & $\begin{array}{l}.38 * * \\
(.15)\end{array}$ & $\begin{array}{l}.43^{* *} \\
(.14)\end{array}$ \\
\hline Border District & - & $\begin{array}{l}16.89 * * * \\
(1.47)\end{array}$ & - & $\begin{array}{l}22.84 * * * \\
(2.43)\end{array}$ \\
\hline Southern District & - & $\begin{array}{l}-7.18 * * * \\
(.74)\end{array}$ & - & $\begin{array}{l}-5.79 * * * \\
(.32)\end{array}$ \\
\hline$\overline{\mathrm{R}^{2} \text { (within } \mathrm{R}^{2} \text { for FE models) }}$ & .626 & .407 & .623 & .655 \\
\hline Root Mean ${ }^{2}$ Error & - & 10.29 & - & 8.47 \\
\hline $\begin{array}{ll}\mathrm{n}=1440 & * \mathrm{p}< \\
\text { Note: Driscoll Kray standard }\end{array}$ & $\begin{array}{l}* * \mathrm{p}<.01 \quad * * * \mathrm{p} \\
\text { parentheses, }\end{array}$ & (one-tailed tests) & & \\
\hline
\end{tabular}


Figure 2: Expected Rates of Judge-Initiated Departures based upon Q1 and Q3 levels of State Crime Rates and State Liberalism, Respectively

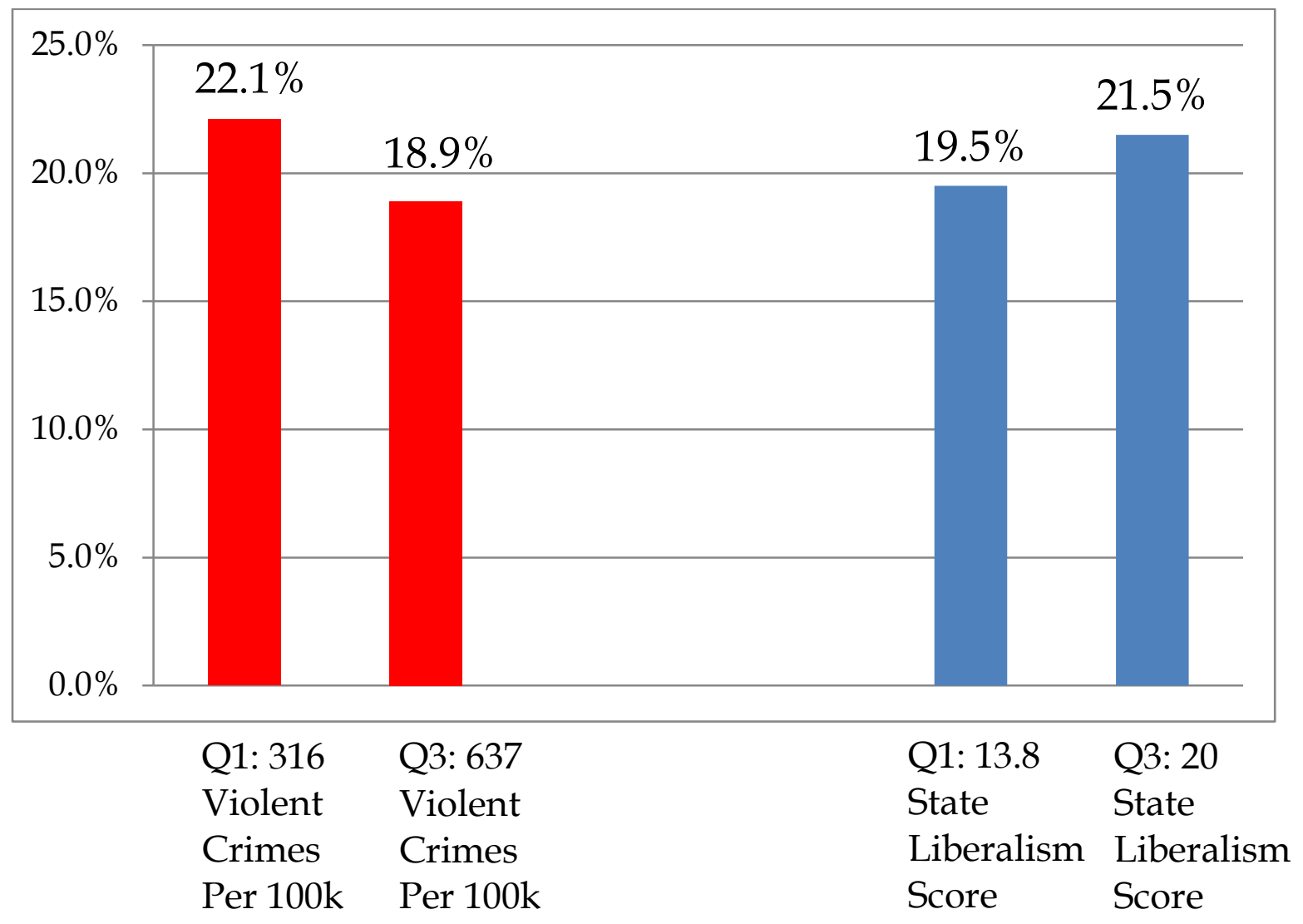

*Note: Fixed-Effect Model, All Other Variables Held at Means. 


\title{
Appendix A: Description and Coding of Variables
}

\author{
State Crime Rate \\ \# of Violent Crimes per 100,000 citizens in each U.S. State in each calendar year \\ State Liberalism \\ Enns and Koch (2013) Measure of Liberalism for Every State from 1996-2010 \\ Dummy variable coded based on the proportion of each Fiscal Year that US v. Booker was in effect. \\ Booker \\ *Note: all Fiscal Years prior to FY2005 were coded 0, all Fiscal Years after FY2005 were coded 1. FY2005 \\ was coded as .745 reflecting the proportion of sentences after US v. Booker was decided* \\ Dummy variable coded based on the proportion of the Fiscal Year that the PROTECT Act was in effect. \\ PROTECT Act \\ *Note: all Fiscal Years prior to 2003 were coded 0, all Fiscal Years after 2005 were coded 1. FY2003 was \\ coded .417 reflecting the proportion of sentences in FY2003 after the PROTECT Act was enacted. FY2005 \\ was coded as .255 reflecting the proportion of sentences after the PROTECT Act was partially overturned by \\ US v. Booker.* \\ \# of active, full-time District Court Judges in Each District and Fiscal Year. \\ \# of Judges \\ *Note: Judges must be active full-time for more than (50\%) of a Fiscal Year to be included in measure \\ **Note: "Senior Status" judges, with significantly reduced caseloads were excluded (See Fischman and \\ Schanzenbach 2011) \\ $\%$ Democrat \\ Judges \\ \# of Districts Per State \\ $\%$ of "\# of Judges" Appointed by a Democratic President in each District and Fiscal Year. \\ Total \# of Federal Districts per State \\ $\%$ Male \\ Offenders \\ $\%$ African-Americans \\ Offenders \\ $\%$ Male Offenders in Each District and Fiscal Year \\ $\%$ Hispanic \\ Offenders \\ $\%$ Drug \\ Trafficking \\ $\%$ Firearm \\ $\%$ Immigration \\ $\%$ Fraud \\ $\%$ Plea \\ $\%$ Mandatory \\ Minimum \\ $\%$ Substantial \\ Assistance \\ Caseload \\ $\%$ Above \\ Median Sentence \\ Border District \\ $\%$ African-Americans Offenders in Each District and Fiscal Year \\ $\%$ Hispanic Offenders in Each District and Fiscal Year \\ $\%$ of Total Offenses that were Classified as Drug Trafficking by USCC in Each District and Fiscal Year \\ $\%$ of Total Offenses that were Classified as Firearms by USCC in Each District and Fiscal Year \\ $\%$ of Total Offenses that were Classified as Immigration by USCC in Each District and Fiscal Year \\ $\%$ of Total Offenses that were Classified as Fraud by USCC in Each District and Fiscal Year \\ $\%$ of Sentences that Followed Conviction by Plea agreement, as Opposed to Conviction by Trial in Each \\ District and Fiscal Year \\ $\%$ of Sentences Subject to a Statutory Mandatory Minimum Penalty in Each District and Fiscal Year \\ $\%$ Of Sentences That Received 5.K 1.1 Departures From The Guideline Range Based Upon Providing \\ "Substantial Assistance" To The Government in the Prosecution of Another in Each District And Fiscal Year \\ \# of Criminal Findings per Authorized Judgeship in Each District and Fiscal Year \\ $\%$ of Sentences in Each District and Fiscal Year that fell above the Median Sentence for that same Fiscal Year \\ across the United States \\ Dummy Variable Coded 1 for the Southern District of California, Arizona, New Mexico, the Western District \\ of Texas, and the Southern District of California and Coded 0 for all Other Districts. \\ Dummy Variable Coded 1 for all districts within the US Census Bureau Identified "South", and coded "0" for \\ all other districts \\ Southern District \\ *Note: This includes all districts within Virginia, North Carolina, South Carolina, Tennessee, Georgia, \\ Alabama, Florida, Mississippi, Louisiana, Arkansas, Oklahoma, Texas, West Virginia, Maryland, and \\ Delaware*
}


Appendix B: Fixed and Random Effect Determinants of District Total Downward Departure \% and Judge-Initiated Downward Departure \% in 90 districts (FY 1996-2011) (Full Model)

\begin{tabular}{|c|c|c|c|c|}
\hline Variable & $\begin{array}{l}\text { Total } \\
\text { Downward } \\
\text { Departure \% } \\
\text { (Fixed Effect) } \\
\text { (1) }\end{array}$ & $\begin{array}{l}\text { Total } \\
\text { Downward } \\
\text { Departure \% } \\
\text { (Random Effects) } \\
\text { (2) }\end{array}$ & $\begin{array}{l}\text { Judge-Initiated } \\
\text { Downward } \\
\text { Departure \% } \\
\text { (Fixed Effects) } \\
\text { (3) }\end{array}$ & $\begin{array}{l}\text { Judge-Initiated } \\
\text { Downward } \\
\text { Departure \% } \\
\text { (Random Effects) } \\
\text { (4) }\end{array}$ \\
\hline State Crime Rate & $\begin{array}{l}-.011 * * * \\
(.002)\end{array}$ & $\begin{array}{l}-.007 * * * \\
(.001)\end{array}$ & $\begin{array}{l}-.010^{* * *} \\
(.002)\end{array}$ & $\begin{array}{l}-.005^{* * * *} \\
(.001)\end{array}$ \\
\hline State Liberalism & $\begin{array}{l}.20 * \\
(.09)\end{array}$ & $\begin{array}{l}.52 * * * \\
(.06)\end{array}$ & $\begin{array}{l}.32 * \\
(.17)\end{array}$ & $\begin{array}{l}.41 * * * \\
(.08)\end{array}$ \\
\hline Booker & $\begin{array}{l}9.18 * * * \\
(2.56)\end{array}$ & $\begin{array}{l}6.59 * * * \\
(0.15)\end{array}$ & $\begin{array}{l}13.21 * * * \\
(3.06)\end{array}$ & $\begin{array}{l}13.18 * * * \\
(2.34)\end{array}$ \\
\hline PROTECT Act & $\begin{array}{l}-5.04 * * * \\
(1.22)\end{array}$ & $\begin{array}{l}-7.76^{* * *} \\
(1.61)\end{array}$ & $\begin{array}{l}-6.07 * * * \\
(1.78)\end{array}$ & $\begin{array}{l}-6.80 * * * \\
(1.75)\end{array}$ \\
\hline $\begin{array}{l}\text { \% Democrat } \\
\text { Judges }\end{array}$ & $\begin{array}{l}06^{* * *} \\
(.01)\end{array}$ & $\begin{array}{l}.002 \\
(.054)\end{array}$ & $\begin{array}{l}.07 * * * \\
(.01)\end{array}$ & $\begin{array}{l}.04 * * \\
(.01)\end{array}$ \\
\hline $\begin{array}{l}\text { \# of Districts } \\
\text { In State }\end{array}$ & - & $\begin{array}{l}1.76 * * * \\
(.35)\end{array}$ & - & $\begin{array}{l}.81 * \\
(.39)\end{array}$ \\
\hline \# of Judges & $\begin{array}{l}-.43 \\
(-0.66)\end{array}$ & $\begin{array}{l}.19 * * \\
(.07)\end{array}$ & $\begin{array}{l}-.70 \\
(.41)\end{array}$ & $\begin{array}{l}.09 \\
(.08)\end{array}$ \\
\hline $\begin{array}{l}\% \text { Male } \\
\text { Offenders }\end{array}$ & $\begin{array}{l}-.09 \\
(.09)\end{array}$ & $\begin{array}{l}.13 \\
(.10)\end{array}$ & $\begin{array}{l}.17 \\
(.07)\end{array}$ & $\begin{array}{l}.07 \\
(.08)\end{array}$ \\
\hline $\begin{array}{l}\% \text { African-American } \\
\text { Offenders }\end{array}$ & $\begin{array}{l}-.07^{* *} \\
(.03)\end{array}$ & $\begin{array}{l}.03 \\
(.03)\end{array}$ & $\begin{array}{l}-.04 * \\
(.03)\end{array}$ & $\begin{array}{l}-.003 \\
(.02)\end{array}$ \\
\hline $\begin{array}{l}\% \text { Hispanic } \\
\text { Offenders }\end{array}$ & $\begin{array}{l}-.12^{* *} \\
(.05)\end{array}$ & $\begin{array}{l}-.05^{*} \\
(.03)\end{array}$ & $\begin{array}{l}-.05 \\
(.06)\end{array}$ & $\begin{array}{l}.04 \\
(.04)\end{array}$ \\
\hline $\begin{array}{l}\text { \% Drug } \\
\text { Trafficking }\end{array}$ & $\begin{array}{l}.24 * \\
(.13)\end{array}$ & $\begin{array}{l}.10 \\
(0.15)\end{array}$ & $\begin{array}{l}.02 \\
(.11)\end{array}$ & $\begin{array}{l}-.01 \\
(.07)\end{array}$ \\
\hline$\%$ Firearm & $\begin{array}{l}-.27 * * * \\
(.08)\end{array}$ & $\begin{array}{l}-.13^{*} \\
(.08)\end{array}$ & $\begin{array}{l}-.21 * * \\
(.08)\end{array}$ & $\begin{array}{l}-.24 * * * \\
(.04)\end{array}$ \\
\hline \% Immigration & $\begin{array}{l}.06 \\
(.06)\end{array}$ & $\begin{array}{l}.05 \\
(.06)\end{array}$ & $\begin{array}{l}.02 \\
(.07)\end{array}$ & $\begin{array}{l}.03 \\
(.06)\end{array}$ \\
\hline$\%$ Fraud & $\begin{array}{l}.03 \\
(.06)\end{array}$ & $\begin{array}{l}.12 \\
(.08)\end{array}$ & $\begin{array}{l}.02 \\
(.06)\end{array}$ & $\begin{array}{l}.02 \\
(.07)\end{array}$ \\
\hline$\%$ Plea & $\begin{array}{l}.47 * * \\
(.18)\end{array}$ & $\begin{array}{l}.58 * * * \\
(.16)\end{array}$ & $\begin{array}{l}.21 \\
(.17)\end{array}$ & $\begin{array}{l}.18 \\
(.21)\end{array}$ \\
\hline $\begin{array}{l}\text { \% Mandatory } \\
\text { Minimum }\end{array}$ & $\begin{array}{l}-.07 \\
(.16)\end{array}$ & $\begin{array}{l}-.04 \\
(.12)\end{array}$ & $\begin{array}{l}-.25^{*} \\
(.15)\end{array}$ & $\begin{array}{l}-.33 * * * \\
(.09)\end{array}$ \\
\hline $\begin{array}{l}\text { \% Substantial } \\
\text { Assistance }\end{array}$ & - & - & $\begin{array}{l}.01 \\
(.02)\end{array}$ & $\begin{array}{l}-.07 * * \\
(.03)\end{array}$ \\
\hline Caseload & $\begin{array}{l}.015 \\
(.010)\end{array}$ & $\begin{array}{l}.010 \\
(.011)\end{array}$ & $\begin{array}{l}.01 \\
(.01)\end{array}$ & $\begin{array}{l}-.001 \\
(.008)\end{array}$ \\
\hline $\begin{array}{l}\text { \% Above } \\
\text { Median Sentence }\end{array}$ & $\begin{array}{l}.28^{*} \\
(.14)\end{array}$ & $\begin{array}{l}.22 \\
(.15)\end{array}$ & $\begin{array}{l}.38^{* * *} \\
(.15)\end{array}$ & $\begin{array}{l}.43 * * \\
(.14)\end{array}$ \\
\hline Border District & - & $\begin{array}{l}16.89 * * * \\
(1.47)\end{array}$ & - & $\begin{array}{l}22.84 * * * * \\
(2.43)\end{array}$ \\
\hline Southern District & - & $\begin{array}{l}-7.18 * * * \\
(.74)\end{array}$ & - & $\begin{array}{l}-5.79 * * * \\
(.32)\end{array}$ \\
\hline $\begin{array}{l}\mathrm{R}^{2} \text { (within } \mathrm{R}^{2} \text { for FE models) } \\
\text { Root Mean }{ }^{2} \text { Error }\end{array}$ & $\begin{array}{l}.626 \\
-\end{array}$ & $\begin{array}{l}.407 \\
10.29\end{array}$ & $\begin{array}{l}.623 \\
-\end{array}$ & $\begin{array}{l}.655 \\
8.47\end{array}$ \\
\hline
\end{tabular}


Appendix C: Fixed and Random Effect Determinants of District Total Downward Departure \% and Judge-Initiated Downward Departure \% in 90 districts (FY 1996-2011)

*Utilizing GLS Estimator (For Random Effects Models) and Fixed Effects Estimator, with District-Clustered Standard Errors.

${ }^{* *}$ Control Variables omitted. Contact Author for Full Tables.

\begin{tabular}{|c|c|c|c|c|}
\hline Variable & $\begin{array}{l}\text { Total } \\
\text { Downward } \\
\text { Departure \% } \\
\text { (Fixed Effect) }\end{array}$ & $\begin{array}{l}\text { Total } \\
\text { Downward } \\
\text { Departure \% } \\
\text { (Random Effects) }\end{array}$ & $\begin{array}{l}\text { Judge-Initiated } \\
\text { Downward } \\
\text { Departure \% } \\
\text { (Fixed Effects) }\end{array}$ & $\begin{array}{l}\text { Judge-Initiated } \\
\text { Downward } \\
\text { Departure \% } \\
\text { (Random Effects) }\end{array}$ \\
\hline & (1) & (2) & (3) & (4) \\
\hline State Crime Rate & $\begin{array}{l}-.009 * \\
(.004)\end{array}$ & $\begin{array}{l}-.006^{*} \\
(.003)\end{array}$ & $\begin{array}{l}-.010 * * \\
(.004)\end{array}$ & $\begin{array}{l}-.006 * * \\
(.003)\end{array}$ \\
\hline State Liberalism & $\begin{array}{l}.16 \\
(.10)\end{array}$ & $\begin{array}{l}.29 * \\
(.10)\end{array}$ & $\begin{array}{l}.30 * * \\
(.09)\end{array}$ & $\begin{array}{l}.36 * * * \\
(.08)\end{array}$ \\
\hline $\mathrm{R}^{2}$ (within $\mathrm{R}^{2}$ for FE models) & .38 & .46 & .62 & .64 \\
\hline
\end{tabular}


Appendix D: Random Effects Determinants of District Total Downward Departure \% and Judge-Initiated Downward Departure \% in 90 districts (FY 1996-2011)

*Utilizing OLS with Panel-Corrected Standard Errors.

${ }^{*}$ Control Variables Omitted. Contact Author for Full Tables.

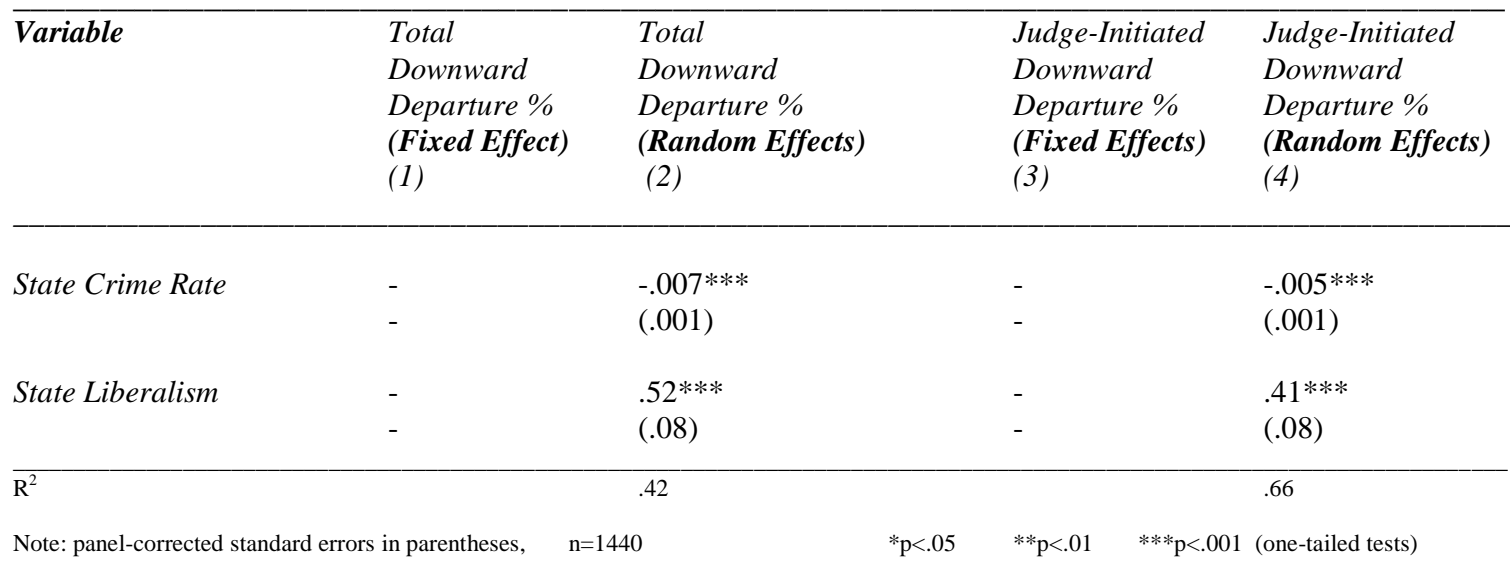


Appendix E: Fixed and Random Effect Determinants of District Total Downward Departure \% and Judge-Initiated Downward Departure \% in 90 districts (FY 1996-2011)

\section{*Utilizing Matching FY and Calendar Year Variables}

${ }^{* *}$ Control Variables Omitted. Contact Author for Full Tables.

\begin{tabular}{|c|c|c|c|c|}
\hline Variable & $\begin{array}{l}\text { Total } \\
\text { Downward } \\
\text { Departure \% } \\
\text { (Fixed Effect) } \\
\text { (1) }\end{array}$ & $\begin{array}{l}\text { Total } \\
\text { Downward } \\
\text { Departure \% } \\
\text { (Random Effects) } \\
\text { (2) }\end{array}$ & $\begin{array}{l}\text { Judge-Initiated } \\
\text { Downward } \\
\text { Departure \% } \\
\text { (Fixed Effects) } \\
\text { (3) }\end{array}$ & $\begin{array}{l}\text { Judge-Initiated } \\
\text { Downward } \\
\text { Departure \% } \\
\text { (Random Effects) } \\
\text { (4) }\end{array}$ \\
\hline State Crime Rate & $\begin{array}{l}-.012 * * * \\
(.003)\end{array}$ & $\begin{array}{l}-.006 * * \\
(.003)\end{array}$ & $\begin{array}{l}-.010 * * * \\
(.003)\end{array}$ & $\begin{array}{l}-.005 * * \\
(.002)\end{array}$ \\
\hline State Liberalism & $\begin{array}{l}.15 \\
(.11)\end{array}$ & $\begin{array}{l}.48 * * * \\
(.07)\end{array}$ & $\begin{array}{l}.28 * \\
(.16)\end{array}$ & $\begin{array}{l}.41^{* * *} \\
(.08)\end{array}$ \\
\hline $\mathrm{R}^{2}$ (within $\mathrm{R}^{2}$ for FE models) & .38 & .42 & .62 & .66 \\
\hline
\end{tabular}


Appendix F: Fixed and Random Effect Determinants of District Total Downward Departure \% and Judge-Initiated Downward Departure \% in 90 districts (FY 1996-2011)

*Including Year Dummies.

${ }^{* *}$ Control Variables Omitted. Contact Author for Full Tables.

\begin{tabular}{|c|c|c|c|c|}
\hline Variable & $\begin{array}{l}\text { Total } \\
\text { Downward } \\
\text { Departure \% } \\
\text { (Fixed Effect) } \\
\text { (1) }\end{array}$ & $\begin{array}{l}\text { Total } \\
\text { Downward } \\
\text { Departure \% } \\
\text { (Random Effects) } \\
\text { (2) }\end{array}$ & $\begin{array}{l}\text { Judge-Initiated } \\
\text { Downward } \\
\text { Departure \% } \\
\text { (Fixed Effects) } \\
\text { (3) }\end{array}$ & $\begin{array}{l}\text { Judge-Initiated } \\
\text { Downward } \\
\text { Departure \% } \\
\text { (Random Effects) } \\
\text { (4) }\end{array}$ \\
\hline State Crime Rate & $\begin{array}{l}-.006^{*} \\
(.002)\end{array}$ & $\begin{array}{l}-.005 * * * \\
(.001)\end{array}$ & $\begin{array}{l}-.005^{* *} \\
(.002)\end{array}$ & $\begin{array}{l}-.004 * * * \\
(.002)\end{array}$ \\
\hline State Liberalism & $\begin{array}{l}.25^{*} \\
(.09)\end{array}$ & $\begin{array}{l}.54 * * * \\
(.07)\end{array}$ & $\begin{array}{l}.34^{*} \\
(.13)\end{array}$ & $\begin{array}{l}.41 * * * \\
(.08)\end{array}$ \\
\hline $\mathrm{R}^{2}$ (within $\mathrm{R}^{2}$ for FE models) & .53 & .45 & .70 & .66 \\
\hline
\end{tabular}




\title{
Chapter 4:
}

\section{"In Their Words: The Sentencing Decisions of Federal District Court Judges According to Judges and Attorneys."}

\begin{abstract}
:
Previous quantitative studies of federal district court judges have largely focused on the impact of partisan or ideological preferences of judges. While a valuable inquiry, I argue that these studies fail to provide a comprehensive understanding of district judge behavior, due to the lack of attention to local contextual influences within district court judges' individual districts. In the context of the criminal sentencing, many scholars acknowledge the import of local contextual factors but analyses are too often reduced to generalities, such as “culture”, leaving several questions unanswered. To gain a deeper understanding of district court judges' criminal sentencing decisions, I conduct nineteen semi-structured interviews with district court judges, former district court judges, and experienced criminal attorneys in four selected districts. Interview subjects were asked both to opine on district court judges' sentencing behavior generally and to assess whether four specific contextual factors impacted judicial sentencing decisions: 1) local legal community opinion; 2) public opinion; 3) incarceration rates; and 4) crime rates. Results were mixed for each factor and there was a lack of consensus amongst subjects as to whether district court judges are influenced by the identified contextual factors. However, the vast majority of subjects cited at least one contextual factor as influential in shaping district court judges' sentencing decisions. More broadly the results advance understandings of district judge sentencing behavior by providing evidence both that certain judges actually altered their sentencing preferences in response to changing conditions and that partisan/ideological differences in district judges may be relatively unimportant in explaining differences in sentencing decisions.
\end{abstract}


"[Criminal sentencing] is a very important task of judges. It takes a lot of reflection. Families of victims and litigants are very concerned about what happens. Judges have to take their time to get it right and do justice."

-Former Federal District Court Judge

\section{Introduction.}

As the above-quote illustrates, criminal sentencing is one of the most important tasks federal district court judges face. But not only are these decisions important, they are also incredibly complicated. The complex federal sentencing process compels district court judges to consider many different factors, most of which they have no personal control over. These include the facts of each case, the personal qualities of individual offenders, the recommended sentence range of the United States Sentencing Guidelines ("Guidelines"), the application of other relevant legal standards, and many additional considerations posed by both prosecuting and defense attorneys. Each of these factors undoubtedly plays a role in sentencing outcomes. Yet despite these external elements, in the majority of federal cases ${ }^{64}$, and as illustrated by the abovequote, the ultimate decision for the "appropriate" sentence rests with district judges' themselves.

Given this important role, and given the increasing attention to the deleterious effects mass incarceration has on society (Currie 2013; Alexander 2012; Pattillo, et. al. 2004; Western 2002), it is imperative to understand what factors district court judges consider when they make their sentencing decisions. Many recent research efforts have studied the more general question of what inputs account for sentencing disparities for similar crimes in the federal system (Lynch and Omori 2014; Wu and Spohn 2010; Ulmer 2005; Kautt 2002). Other research has framed the issue in terms of how district judges' partisan preferences interact with changing legal

\footnotetext{
${ }^{64}$ A substantial minority of federal offenders (between 20-30\% depending on the year) are convicted of crimes that carry a "mandatory minimum" penalty, in which district judges have no discretion to unilaterally sentence criminals to shorter sentences than the proscribed statutory period (USSC 2011).
} 
constraints on their sentencing discretion (Epstein, et. al. 2013; Fischman and Schanzenbach 2011).

This research has provided improved understandings of why we observe disparities in sentencing outcomes for similarly situated offenders (Lynch and Omori 2014; Wu and Spohn 2010; Kautt 2002; Mustard 2001). It has also shown how recent legal developments have allowed district court judges to obtain authority to arrive at their preferred sentence (Epstein, et. al. 2013; Fischman and Schanzenbach 2011). However, I claim that this research has left two major questions pertinent to federal sentencing policy largely unanswered: 1) the sustained decline in the punitive behavior of district judges over time; and 2) the observed geographic variation in the sentencing behavior of district judges.

I argue that these two phenomena are best explained not by simply the partisan/ideological preferences of district judges or by changes in levels of judicial discretion, but instead by certain district-specific contextual factors. Specifically, in this work, I study the potential impact of four such contextual factors: 1) the punitive preferences of legal elites; 2) the punitive preferences of the broader public; 3) crime rates; and 4) incarceration rates. The theoretical basis for each of these factors is explained in greater detail both in Chapters 1-3 and below. But the broader theory of contextual influence is based upon the logic that district judges both care about their professional reputations within their respective district and the policy consequences of their decisions in these districts. Thus, to the extent both punitive preferences among certain groups and relevant objective conditions in communities vary across time and space, these differences will partially explain differences in district judges' decisions. 
Chapters 2 and 3 of this dissertation have used various quantitative methods to empirically test variants of this central question of contextual influence. This chapter takes a different approach. Namely, I employ qualitative phone-interviews with elite legal actors who possess substantial experience in federal sentencing. Interview subjects include current district judges, former district judges, former and current U.S. attorneys, federal public defenders, and private practice criminal defense attorneys. As I will argue, this interview-based methodology is particularly well-suited for a study of district judge behavior, because it can provide a deeper understanding of the different contexts in which district court judges operate.

In this chapter, I proceed as follows. First, I briefly review and summarize different theoretical perspectives of judicial behavior and explain their application to federal sentencing. Second, I explore the two specific puzzles left unexplained by previous sentencing research. Third, I discuss the value of using qualitative interviews as part of a mixed-methods approach to uncover determinants of district court sentencing behavior. Fourth, I explain and defend the methods used to gather interview subject and collect data. Fifth, I present the results of the research, intermixing both descriptive statistics and specific quotes from interview subjects. Finally, I assess how the results square with various theories and discuss potential avenues for future research.

\section{Theories of Judicial Behavior in the Context of Federal Sentencing}

There is general scholarly consensus that trial court behavior is understudied in the subfield of judicial behavior (Epstein, et. al. 2013; Posner 2010; Kim, et. al. 2009). Part of the difficulty with empirical studies of trial court behavior is that scholars have fewer tools at their disposal for analyzing and comparing trial courts when compared with appellate courts. First, appellate judges generally sit on panels with other judges. Thus, multiple judges vote on the 
outcome of the exact same case. In contrast, trial judges adjudicate cases solely, and it is rare for any two trial judges to hear the exact same case. This feature obviously makes testing theories of trial court behavior relatively difficult.

Another difficulty for scholars of trial courts is the dearth of written opinions. Appellate cases almost always produce written opinions, wherein judges/justices justify and explain their decisions. Accordingly, studies of appellate voting behavior (Segal and Spaeth 2002; Epstein and Knight 1997) or citation decisions (Hinkle 2015; Hume 2009) can provide insight into how jurists arrive at their decisions. In the absence of written opinions or voting data, studies of trial court judge behavior must often use more creative approaches. ${ }^{65}$

Despite the potential research limitations facing students of trial judges, several scholars have sought to explain the motivations behind trial court behavior. While general theories of trial judges posit that judges are influenced by a multitude of factors (Kim, et. al. 2009; Rowland and Carp 1996; Kritzer 1978), some determinants have received more scholarly attention than others. To cite the most prominent example, several research efforts examine the impact of judges' personal partisanship and/or ideology on case outcomes. Some of this scholarship finds that, like appellate judges, trial judges' decisions are strongly influenced by their partisanship or ideology (Sisk \& Heise 2012; Stidham, et. al. 1996; Rowland, et. al. 1996). In contrast, other research on trial courts has found little or no impact of partisan or ideological variables (Zorn \& Bowie 2010; Ashenfelter, et. al. 1995). While certainly valuable to the study of trial court behavior, a debate focused solely on whether partisanship or ideology impacts decisions potentially overlooks other potentially important explanations.

\footnotetext{
${ }^{65}$ For example, in their study of California trial judges, Blank, et. al. (1989) videotape judges presiding over criminal trials and then code the judges' verbal and nonverbal behavior along ten different paradigms (e.g. warm/not warm, professional/non-professional).
} 
Specifically, I argue that contextual factors, related to the environments in which trial judges sit, can ultimately shape these judges' decisions. This is not a novel view. Several scholars of judicial behavior have demonstrated that trial judges' decisions often depend upon the different contexts in which they make these decisions (Rowland \& Carp 1996; Kritzer, et. al. 1993; Gibson 1980; Kritzer 1978; Cook 1973; Peltason 1964; Vines 1961). ${ }^{66}$

But with respect to federal criminal sentencing, what type of contextual variables might we expect to be influential? Stated differently, what different conditions might explain differences in district judges' sentencing decisions? I posit four potential sources of contextual influence worthy of exploration.

\section{Reputational Factors: Local Legal Community Influence \& Public Influence}

Both for reasons of career advancement (Morriss, et. al. 2005) and for the personal desire to be liked and respected (Posner 2010; Baum 1994), many district judges desire to foster a good reputation within the local legal community. Baum (2006) argues that judges with limited jurisdiction, such as district judges, see lawyers whom they interact with as a key audience whose opinions "may sway judges" (98).

In fact, I argue that federal criminal sentencing is one area we would particularly expect to observe influence from the local legal community. This is first because the majority of members of the legal community view the current federal sentencing regime as both incredibly important and overly punitive (Hofer and Allenbaugh 2003; Sisk, et. al. 1998). Thus, district judges' sentencing reputations are likely to be a significant factor upon which legal community evaluations of them are made. In addition, there is strong evidence that district-specific legal norms affect sentencing outcomes in separate districts (Ulmer 2005). Likely due to measurement difficulties, these works do not specifically study the connection between the punitive preference

\footnotetext{
${ }^{66}$ For a more thorough review of these pieces, see Chapter 1.
} 
of the legal community and district judge sentencing. Yet the fact that district-specific legal norms impact sentencing outcomes suggests that local legal communities may hold some influence over district judges.

It is also quite plausible that the punitive preferences of the general public affect the sentencing behavior of district judges. The extent to which the U.S. Supreme Court takes on a "representational role" and responds to public opinion has been the subject of much debate in the judicial behavior sub-field (Casillas, et. al. 2011; Segal and Spaeth 2002; Mishler and Sheehan 1996). Yet because district judges live and work within specific local districts, and because they deal directly with members of their community every day, it is likely that these trial judges are more representative of the local public than appellate judges (Rowland and Carp 1996).

Indeed, studies of district judges from past decades often tested the impact of public influence on district judges (Silver and Shapiro 1984; Kritzer 1978; Cook 1973, 1977; Peltason 1971; Vines 1964). Indeed, with respect to criminal sentencing, Cook (1973) finds that the decline in public support for the Vietnam War caused district judges to be less punitive in their sentences for draft dodgers. Yet recent Guideline-era sentencing scholarship has largely ignored any role in public influence on district judges. This is in spite of the fact that the public's punitive preferences vary by region (Jacobs and Carmichael 2001) and have changed markedly over time (Enns 2014). Indeed, as demonstrated in Chapter 3 of this dissertation, it is possible that the public's ideological preferences explain regional and temporal differences in judges' sentencing behavior. ${ }^{67}$ Still, whether district judges actually consider public preferences when making individual sentencing decisions remains an open question.

\footnotetext{
${ }^{67}$ There is serious debate regarding causality and reputational influences. Segal and Spaeth (2002) argue that any public influence on unelected judges is likely indirect, as judges are simply members of the public. On the other hand, Mishler and Sheehan (1996) and Casillas, et. al. (2011), argue that direct influence is present and that judges are actually responsive to public opinion some degree. My theoretical perspective is consistent with aspects of both
} 


\section{Objective Conditions: Crime Rates \& Incarceration Rates}

Aside from reputation-based factors, another source of potential contextual influence on district court judges are the objective conditions related to crime and punishment in their local community. The reasoning for why these facts might influence judges is based on the assumption that judges seek to make their own view of good public policy (Epstein, et. al. 2013; Posner 2010; Posner 2009; Segal and Spaeth 2002; Songer 1979). Undoubtedly, judges' views of "good policy" are shaped by individual factors, such as personal partisanship, political ideology, and personal background (Epstein, et. al. 2013; Segal and Spaeth 2002; Sisk and Heise 2012). However, I argue that these explanations are important but incomplete. Given district court judges' social connections with their geographic constituency, judicial views of "good" policy are likely supplemented by salient conditions existing in their community.

Assuming judges sometimes seek to bring about the "best" consequences with their decisions (Posner 2009; Songer 1979), it is at least plausible that judges' normative evaluations are informed by pertinent objective information, in addition to any preexisting partisan or ideological biases. While social scientists have studied the impact of objective conditions on the behavior of the general public (Page, et. al., 1987) and other policymakers (Jones \& Baumgartner 2005; Cohen 1999), there has been little testing with respect to judges. Since trial judges generally live and work in the communities where they have jurisdiction (Rowland and Carp 1996), it is likely that the conditions in these communities are an important determinant of judges" "preferences."

sides of the debate. In other words I would expect judges to adjust their behavior to conform to the opinions of those audiences they seek a good reputation with. However, in lieu of direct influence, to the extent judges simply hold preferences that are consistent with local legal elites or the local public, this is consistent with my argument that sentencing outcomes must be viewed through the prism of local contexts (see Chapter 1, Figure 1). 
The two objective conditions I address in this work are crime rates and incarceration rates. The logic underlying crime rate influence on sentencing behavior is that higher crime will prod judges to punish and deter criminal offenders through longer sentences. There is also some evidence for this phenomenon. Both Gibson (1980) and Ulmer and Bradley (2006) found that state-elected judges sentenced criminals more harshly in higher crime rate areas. In addition, several of the models presented in Chapter 3 of this dissertation found a relationship between high crime rates and fewer below-Guideline sentences. However, the question is not settled as Johnson, et. al. (2008) found no relationship between crime rates and sentence length for certain federal crimes at a given point in time. ${ }^{68}$ In addition, there are many potential conflating factors intertwined with crime rates (urban/rural areas, caseloads, etc.), which might explain correlations between crime rates and sentences. Overall, all of the above suggests further inquiry into the crime rate/judicial sentences connection is prudent.

The reasoning behind incarceration rate influence on district judges' sentencing preferences is slightly different. Here, the logic is that, despite their defined role as neutral arbiters of the law, judges generally seek to arrive at decisions that provide the most workable consequences (Posner 2009). This notion of judges as pragmatists suggests that they seek to avoid or mitigate negative policy effects.

By 2016, it is fairly uncontroversial to claim that the policy of mass federal incarceration is generally regarded as a failure in policy (Clear and Frost 2015). Large segments of both major political parties in the United States are now supportive of sentencing reform efforts to reduce the number of non-violent, incarcerated individuals. ${ }^{69}$ To a limited degree, district judges have the opportunity to mitigate this policy of long sentences absent-congressional action. If district

\footnotetext{
${ }^{68}$ For a further discussion of Johnson, et. al. (2008), see Chapter 3 of this Dissertation.

${ }^{69}$ See e.g. H.R. 3713; S. 2123
} 
judges truly see to make the best policy, it is likely that they would be influenced by the surge in federal incarcerations and respond accordingly with more below-Guideline sentences.

To be sure, the effect of incarceration rates might depend on whether individual judges see their role in government as active or passive (Scheb, et. al. 1993). Still, just as proponents of the attitudinal model argue it is implausible to assume judges divorce their ideological preferences from their decisions, I similarly argue it would be unreasonable to believe judges will ignore pertinent objective facts. Stated differently, if some judges care about avoiding negative policy consequences, it is likely those judges take account of pertinent facts relevant to those policy consequences when making decisions.

\section{Contextual Influence and Federal Sentencing}

All of the above suggest that certain contextual factors could impact federal district court judges' sentencing decisions. Yet as discussed more thoroughly both in Chapter 3 and below, most studies examining regional disparities in federal sentencing have tended to focus on differences in prosecutorial practices while de-emphasizing the role of district judges (Lynch and Omori 2014; Wu and Spohn 2010; Ulmer 2005; Kautt 2002). As to the studies that do focus on judicial behavior, they are generally limited to "low hanging fruit" variables of judicial partisanship and legal policy change, to the determinant of other potentially important contextual factors, such as those itemized above (See e.g. Epstein, et. al. 2013; Fischman and Schanzenbach 2011).

Overall, these past studies have undoubtedly improved understandings both why we observe sentence disparities within the complex federal sentencing system (Lynch and Omori 2014; Wu and Spohn 2010; Tiede 2009; Kautt 2002) and how district judges have responded to changes in their levels of discretion (Epstein, et. al. 2013; Fischman and Schanzenbach 2011). 
However, certain questions remain unanswered. In particular, there are two "puzzles" of federal sentencing policy that persist. These are: 1) the gradual and continuing increase in belowGuideline sentences over time; and 2) extreme interdistrict variation in judges' propensity to grant below-Guideline sentences. As I argue in greater detail below, the answer to these two "puzzles" may be explained by the above-discussed contextual influences.

\section{Puzzle \#1: Gradual Increases in Below-Guideline Sentences Over Time}

Federal sentencing policy has changed drastically since the Guidelines were first implemented in 1987. During the first few years after the Guidelines were implemented, federal district court judges sentenced offenders below the Guideline recommended range in less than 20\% of all cases (USSC 1995-2014). However, by Fiscal Year ("FY”) 2014, the last year data was available, a majority of federal offenders were sentenced below the recommended range (USSC 1995-2014). To be sure, part of the explanation for this marked change is the fact that in a 2005 decision, the US Supreme Court clarified that the Guidelines were not "mandatory" but rather "advisory" on federal district court judges (US v. Booker 543 U.S. 220 (2005)). Indeed, the Sentencing Commission, along with several scholars, have provided strong evidence that the Booker decision prompted district judges to sentence below the Guideline-recommended range at increasing rates (Epstein, et. al. 2013; USSC 2012; Fischman and Schanzenbach 2011).

However, as I have argued throughout this dissertation, while Booker was clearly a watershed moment that increased federal district judge sentencing discretion, Booker fails to fully explain the dramatic and continued trend of district court judges sentencing offenders to shorter sentences. If it were simply the case that district court judges were constrained in their sentencing decisions pre-Booker but "freed" post-Booker to sentence their preference, we would expect to see a dramatic increase in Guideline departures post-Booker, followed by a leveling off 
in the proportion of below-Guideline sentences. However, the raw data does not bear this fact out, and below-Guideline sentences have continued to increase in later years. ${ }^{70}$ Current explanations in the literature for the continued post-Booker increase in below-Guideline sentences posit that judges are simply adjusting to the authority given to them by Booker (Epstein, et. al. 2013).

This explanation, however, seems to underestimate the rationality of highly educated district court judges. Booker clearly gave judges the freedom and authority to depart from Guideline sentences. In FY 2006, the first full year after Booker was implemented, only $1.5 \%$ of below-Guideline sentences were overturned by an appellate court (USSC 1995-2014). In other words, as district court judges would surely be aware, there was a very small chance post-Booker that any given sentence would be overturned on appeal for being "too lenient." So assuming that judges are rational actors who seek outcomes consistent with their preferences (Posner 2010), it would seem strange indeed for judges to holster their authority to implement their ideal, more lenient sentences for several years.

\section{Puzzle \#2 Inter-District Variation in Judicial Behavior}

Despite the fact that the Guidelines are intended to be applied identically throughout the country, there is extreme variation in sentencing outcomes among the ninety federal districts (USSC 1995-2014). To be sure, several researchers have noted this phenomenon and conducted empirical tests to uncover the sources of this variation in sentencing outcomes (Lynch and Omori 2014; Fischman and Schanzenbach 2011; Wu and Spohn 2010; Tiede 2009; Ulmer 2005; Kautt

\footnotetext{
${ }^{70}$ It is true that two Supreme Court decisions on December 10, 2007 further clarified that judges had wide discretion to depart from Guideline-recommended decisions (United States v. Kimbrough, 552 U.S. 85 (2007); United States v. Gall, 552 U.S. 38 (2007)). However, these decisions were not of the same watershed character as Booker (2005). Moreover, even we were to assume that the Kimbrough and Gall decisions gave judges the full power they needed to sentence more leniently, these decisions not explain the continued increase in the proportion of sentences below the Guideline recommended range from 39.1\% in FY 2008 to 51.8\% in FY 2014.
} 
2002). A central finding of these studies is that district differences in criminal sentences are partially explained by the differing application and interpretation of sentencing procedures and by district-specific prosecutorial practices (Lynch and Omori 2014; Wu and Spohn 2010; Ulmer 2005; Kautt 2002). ${ }^{71}$

This research focus on court-community norms and prosecutorial practices is important and clearly helps explain much of the sentence-length disparity for offenders in different districts. However this research has largely skirted the issue of why different judges might have different sentencing preferences throughout the country. ${ }^{72}$ Yet an independent focus on judges is important. Regardless of any district-specific differences in prosecutorial practices, there is still marked district variation in how often district judges themselves choose to depart from the Guidelines (USSC 1995-2014). ${ }^{73}$ If we truly want to understand these regional differences in district judges' sentencing, a deeper inquiry into the decision-making process of judges is warranted.

\section{Two Birds with One Stone: Local Contextual Influences}

I posit that a potential explanation for both of the above described puzzles is local, contextual influence. District judges are residents and members of local communities. It is true that district court judges are unelected, enjoy life tenure, and are instructed by law to ignore social and personal considerations. Despite these facts, as discussed in more detail above, there is a wealth of evidence that district court judges care about their reputations in their communities

\footnotetext{
${ }^{71}$ For a more thorough summary of the findings of these individual pieces of research, see Chapter 3.

${ }^{72}$ Indeed, Kautt (2002) models judicial departure rates as an independent variable for explaining sentencing disparity.

${ }^{73}$ See Chapter 3, Footnote 41 . To be sure, not all of the differences in judge-initiated departures exemplified in said footnote can be attributed to differences in district judges' sentencing preferences, as the composition of offenses and offenders also varies across districts. Still, this stark difference in judge-initiated departure rates exemplifies how different prosecutorial policies are insufficient to explain differences between districts.
} 
(Rowland and Carp 1996; Kritzer 1978; Peltason 1971; Vines 1964). Relatedly, there is further evidence that judges gain utility from arriving at what they believe to be "good public policy" (Epstein, et. al. 2013; Posner 2009; Segal and Spaeth 2002; Songer 1979).

Applying this theoretical perspective of local contextual influence to federal sentencing, I argue both reputational concerns and salient objective conditions help explain the two puzzles of federal sentencing outlined above. More specifically, I submit that the dramatic and continually increasing rate at which offenders are given below-Guideline sentences ("Puzzle \#1") is partially explained by increasing evidence of the pernicious consequences of over-incarceration, the falling crime rate, and more recently, the softening sentencing preferences among both legal elites and the general public. As district judges are almost assuredly aware, over the past two decades incarceration rates have increased significantly while crime rates have decreased. Due to these facts, combined with the growing attention to the problem of incarceration, it is likely district judges began viewing longer sentences as ineffective policies. Relatedly, as opinions began to shift in a relatively less punitive direction ${ }^{74}$, judges' opinions shifted in tandem. Therefore, because of both reputational concerns and concerns over the policy consequences of their decisions, district judges began adjusting their preferences and imposing less-draconian sentences.

As to countrywide variation in district judges' propensity to issue below-Guideline sentences ("Puzzle \#2"), I argue that the source of this variation can be partially explained by local contextual influences on judges. Specifically, there is clearly great nationwide variation in the punitive preferences of both elites and the general public (Jacobs and Carmichael 2001). If judges care about their reputations amongst either of these communities, it is quite reasonable to

\footnotetext{
${ }^{74}$ See Enns (2014). While punitiveness has risen markedly among the public over the past several decades, there is evidence suggesting that public punitiveness peaked in the mid-late 1990's.
} 
assume that their own sentencing behavior would, at least somewhat, reflect the preferences of these communities (Baum 2006).

In a similar vein, I argue that varying crime rates also help explain regional variation in judges' punitive sentences across the country. ${ }^{75}$ As discussed above, judges in areas with higher crime might see it as their duty to punish and deter criminals through longer sentences. This factor is likely also linked to reputational concerns, as judges would not want to be perceived as either failing to deal with a serious crime problem, or as being overly-punitive in a community that has very little crime.

To be clear, I do not mean to suggest that the four sources of contextual influence outlined above are the only factors that might influence judges. We know many sentencing outcomes are influenced by facts related to the individual offender and crime (e.g. the criminal history of the offender, whether violence was used). Further, as discussed above, recent research has also evidenced the importance of both prosecution policies (Lynch and Omori 2014; Wu and Spohn 2010) and different levels of discretion for district judges (Epstein, et. al. 2013; Fischman and Schanzenbach 2011) in shaping sentencing outcomes. However, the four contextual determinants probed herein (local legal community preferences, public preferences, crime rates, and incarceration rates) are all theoretically relevant factors that have yet to be sufficiently examined and may help account for the two puzzles of federal sentencing outlined above.

\section{Interview-Based Research}

To test my theoretical perspective, and to gain further insight into judicial sentencing behavior more generally, I employ the method of phone-interviews with experienced actors in

\footnotetext{
${ }^{75}$ For quantitative of the impact of crime rates on judicial sentencing behavior, see Chapter 3 of this Dissertation.
} 
federal criminal sentencing. ${ }^{76}$ There are several reasons why use of this methodology is appropriate. The most pertinent justification for qualitative, interview-based research is that it allows for further mixed-method ${ }^{77}$ testing of my central argument of contextual influence on district court judges' criminal sentencing decisions.

Another reason to conduct interview-based research is its ability to assess the relative value of competing theoretical perspectives, by inquiring as to the opinions of actors who possess first-hand experience with district court judges' sentencing decisions. This method has proved valuable to political scientists studying the behavior of other policymakers, such as Congress (MacDonald 2007; Zegart 2011) and the President (Jacobs and Shapiro 1995). In the context of the sentencing behavior of district court judges, the present research will assist in determining the relative importance of local contextual influences, personal partisan/ideological factors (Fischman and Schanzenbach 2011), prosecutorial practices (Lynch and Omori 2014; Ulmer 2005), or top-down change to legal policy (Epstein, et. al. 2013; Fischman and Schanzenbach 2011; Schanzenbach and Tiller 2007).

Yet another reason to utilize the elite interviewing method is the dynamic nature of federal sentencing. Regardless of geographic differences, a central question of this research is to determine why district judges issued below Guideline sentences about one-third of the time in

\footnotetext{
${ }^{76}$ This interview-based approach was also used by Ulmer (2005) as part of his mixed-method approach to understanding district differences in federal sentencing. While Ulmer's (2005) study clearly demonstrated the value of interviewing sentencing actors, the present study differs in important ways. Ulmer (2005) uses interviews largely to determine how legal actors interpreted certain terms in sentencing parlance (e.g. "substantial assistance") and how these different interpretations could result in disparate sentences. My area of inquiry is distinct, as I seek to probe exactly what factors judges look to in their general sentencing behavior.

77 . that Chapter 2 found little evidence of national-level sociopolitical or public influences on district court sentencing, while Chapter 3 found support for more localized influence of both the crime rate and citizen ideology. Irrespective of these findings, there remains value in using a multitude of methods for theory testing (Martin 2013). In addition, interviews allow for the probing of previously to the probing of untested potential influences, such as local legal community sentiment on sentencing policy.
} 
the wake of Booker but now issue these sentences in over half of all cases ("Puzzle \#1). These types of inquiries, often referred to as "process tracing" attempt to determine the casual chain of how certain events led to a particular policy outcome (George and Bennet 2005). Interviews with elite policymakers has been identified as an important tool in the process tracing method, as they allow for researchers to gain first-hand perspectives of how a policy output evolved in the fashion that it did (Tansey 2007).

Furthermore, targeted interviews of elite policymakers or persons with experience working with these policymakers can provide new insights into the thought processes of how decisions are made (Beckmann and Hall 2013). Regardless of any observed strength of competing theories of judicial influence in quantitative models, probing interviews will provide insight into the mechanism by which those theories derive their validity. Stated differently, experienced interview subjects will be to opine as to why judges' criminal sentencing decisions are (or are not) affected by certain inputs.

Assuredly, interview-based research is not without difficulties ${ }^{78}$, and the opinions of interview-subjects should be assessed critically for both their veracity and their reliability (George and Bennett 2005). Yet, at minimum, the opinions of a diverse sample of actors with years of experience in federal sentencing will provide additional insight into how sentencing decisions are made and what factors are thought to be important to district court judges.

\footnotetext{
${ }^{78}$ See Bleich and Pekkanen (2013) for a more complete discussion of some the problems associated with interviewbased research. As will be explained in more detail, below, the present research design will attempt to mitigate the effects of many of these difficulties.
} 


\section{Methods}

\section{District Selection}

The Federal Court system is made up of ninety ${ }^{79}$ federal districts. Due to time and resource constraints, however, I chose to limit the pool of interview subjects to four districts ${ }^{80}$. A random sampling of all ninety districts, while well-suited to make generalizations about judicial behavior, would likely have led to only a single interview subject for each district studied. This is not ideal for a research effort seeking to gain deeper understandings of local contexts. On the other hand, a within-case study of a single district would also be problematic due to issues of generalizability (George and Bennet 2005). In addition to the problem of generalizability, a single case study could provide no insight into "Puzzle \#2" relating to why judges in different districts sentence differently. Thus, I choose a middle way between random sampling and a single case-study.

In order to ensure the protection of subject confidentiality (Mosley 2013), the four selected districts are will not be identified. However, in order to provide verifiable information regarding case-selection, Table 1 provides aggregate and general information regarding the selected districts. The purpose of Table 1 is to examine the extent to which the findings from the

\footnotetext{
${ }^{79}$ Not including the districts of the U.S. Territories (Guam, Puerto Rico, US Virgin Islands, and the North Mariana Islands).

${ }^{80}$ Originally, I employed a most similar system ("MSS") research design to select the four districts in question. Application of the MSS method involves selecting cases that are similar in most fashions, but where we observe variation in the proposed independent variables and in the dependent variable (Przeworski and Teune 1970). This method allows researchers to control for many alternative explanations that might be causing the observed variation in the dependent variable. However, due to the extremely small subset of interview subjects within each district, the I was not able to make valid comparisons between districts. As a result, the analysis presented herein will largely focus on the aggregate opinions of interview subjects as to whether contextual variables are affecting judges' sentencing decisions, regardless of differences between the districts. In the future, I plan on expanding the subject pool so as to be able to make stronger claims regarding judges operating in different environments.
} 
four selected districts can be generalized to federal district court judges in all ninety federal districts

\section{[Table 1 about here]}

As can be seen from the center column of Table 1, many different areas of the country are represented by the district pool. However, the right hand column of Table 1 also highlights certain districts in the country not represented by the selection. Due to the limited number of districts, the design was unable to include a small, rural district. There is also a lack of any representation in this research of any Western districts, and not coincidentally, districts with relatively large populations of Hispanic-Americans. Thus, to the extent district judges from small/rural districts, Western districts, or districts with large Hispanic populations have unique approaches to criminal sentencing, the present research will not be able to account for those differences. The foregoing is certainly a limitation of this research, but future expansion of this project will seek to address this issue through the inclusion of additional districts.

\section{Identification of Subjects}

Given that the present research is focused on the sentencing behavior of district judges, the judges themselves are obviously an apt target for interviews. This tactic of interviewing judges has been used before to test influences of judicial behavior (Levin 1972; Ulmer 2005; Hilbink 2007). On the other hand, there are several reasons to not limit the inquiry to the response of district court judges alone.

First, there are very real reasons to suspect that district court judges, especially sitting judges $^{81}$, would not be completely candid regarding their sentencing practices. Scholars of

\footnotetext{
${ }^{81}$ This concern of candidness is likely less problematic for retired district judges, who would doubtless be less concerned with their reputations as jurists after leaving the bench. Still, due to the legal training and socialization discussed below, it is still likely that retired judges might have a difficult time admitting any true extralegal motivations for their sentencing behavior.
} 
judicial behavior have pointed out that judges are loathe to admit that any "extralegal" considerations influence their decisions in individual cases (Carp \& Stidham 1996). Perhaps this is due to both legal formalistic training and legal socialization of judges, both of which convince judges the law is blind to such considerations (Spaeth and Segal 2001). Perhaps instead, judges understand that extralegal factors influence them, but due to the fact that they are trained and instructed by law to ignore extralegal factors, it would hurt their reputation to admit their influence. Regardless of the cause, these norms raise concerns that some district court judges would not be candid about extralegal motivations, even in confidential interviews.

Secondly, judges themselves may not be able to accurately describe "why" they do the things they do in criminal sentencing. Researchers of Congress have found that members have difficulty explaining exactly why they vote the way they do (Kingdon 1981; Beckmann and Hall 2013). With respect to judges, many scholars associated with the legal realism movement are skeptical that judges are able to attach their actual motivations to their behavior on the bench (Tiller and Cross 1999).

Finally, limiting interviews to only federal district court judges would likely do damage to the generalizability of the study. Recall that the aim of this research is to achieve a deeper understanding of the sentencing behavior of district court judges who operate in different contexts. Yet, given that district court judges decide cases individually and do not directly observe the sentencing behavior of other judges within their districts, interviews with a small proportion of judges or former judges from each district would not be appropriate for inferring conclusions regarding the district generally. On the other hand, including perspectives from persons with experience appearing before multiple judges within the district could more easily generalize regarding "typical judges" in that district. 
Given these concerns, it is reasonable to supplement district court judge interviews with interviews of non-judges. The non-judicial actors best situated to address judges' sentencing behavior are almost certainly attorneys. As argued recently by a prominent trial-court scholar, researchers seeking to better understand trial court behavior would do well to incorporate studies of attorneys into their approaches (Kritzer 2012). Indeed, as attorneys are often professionally invested in the outcome of district court judges' decisions, it seems as they would have some insight into what factors affect judges in making these decisions.

The attorneys I specifically target as subjects are as follows: 1) attorneys working for U.S. attorneys' offices who prosecute offenders; 2) attorneys working for federal public defenders' offices, who provide criminal defense for indigent offenders; and 3) experienced private-practice federal criminal defense attorneys. Given the potential for interested-parties to have differing views on sentencing policy and judicial behavior (Ulmer 2005), it is important to gain a broad perspective from both attorneys representing the government and those representing the offenders. This tactic helps ensure results are not biased towards a particular source of judicial influence based upon the experiences or incentives of a subset of actors (Bleich and Pekkanen 2013).

In order for attorneys to be meet criteria as an interview subject, they must have experience working in federal criminal sentencing within their district for over ten years. Ten years of experience assures the subjects will have worked with enough judges in the district to be able to make credible generalizations regarding district judge sentencing behavior. The ten year time period is also not arbitrary. 2005 marks the year of the US v. Booker decision. As one primary goal of this research effort is to explain the gradual, as opposed to abrupt, change in 
judicial Guideline adherence since 2005 (“Puzzle \#1"), it is prudent to find subjects who could speak to federal sentencing in the initial aftermath of Booker up through the present.

\section{Contacting the Subjects ${ }^{82}$}

I employ several different techniques to contact as many potential interview subjects as possible. First, I contacted those individuals who unquestionably have knowledge and experience in federal sentencing. In addition to being potential interview subjects, these subjects are also "toehold" subjects who can lead to additional subjects (Beckmann and Hall 2013). The toehold subjects I directly contacted in all four districts were: 1) the U.S. Attorney for each district; 2) the Federal Public Defenders for each district; and 3) each retired ${ }^{83}$ U.S. district judge in the federal districts. These subjects clearly meet the criteria of substantial experience in federal sentencing, and twenty one subjects were contacted via this method.

As my initial means of contact, I sent written requests to all of the above persons, stating the nature of the project, the purposes of the research, and a request for a 45 minute- 1 hour phone interview. The written letters also informed potential subjects that their confidentiality would be protected and that I would be following up within one-two weeks by contacting recipients via phone. After contacting these twenty one potential subjects by phone, I scheduled six interviews with willing participants for a response rate of $29 \%$. After scheduling the interview, I provided subjects with both written and oral informed consent for their participation.

\footnotetext{
${ }^{82}$ This research design was approved and categorized as "exempt" by the West Virginia University Institutional Review Board.

${ }^{83}$ Active district court judges in the four districts were not contacted directly due to their shared professional addresses and concerns over subject confidentiality. In addition, active judges might be less likely to be candid, as they are instructed by law to ignore many extralegal considerations that the interviews would probe (e.g. personal partisanship or public opinion). However, as shown by Table 2, below, two active judges were eventually included as interview subjects after being referred directly by other subjects.
} 
Of course, there are several other persons who may have insight into federal sentencing beyond the toehold respondents discussed above, such as private-practice criminal defense attorneys. However, for this subject pool, I chose a purposive sampling method intended to recruit subjects who could intelligently discuss as to the change and development of federal sentencing practice over the past decade (See Tansey 2007). It would be imprudent to recruit these subjects from a broad pool of attorneys who advertised federal criminal defense, as this may include attorneys who had only recently or rarely appeared in federal court on criminal matters.

Accordingly, in order to recruit additional qualified subjects, I used a second method: I contacted all officers of the Federal Bar Association ("FBA") chapters of each selected district by e-mail correspondence and requested referrals. The FBA is an organization with over 17,000 members and 1,200 federal judges (FBA 2015). The FBA's district chapters, among other tasks, are charged with monitoring federal issues, providing opportunities for scholarship and continuing education, and providing for professional and social interaction between attorneys and judges (FBA 2015). The rationale for contacting the FBA officers is that the officers are likely to have knowledge of the identities of the most experienced persons in the district with respect to federal sentencing. The officers may or may not be involved in criminal law themselves, but they likely will have served actively in their districts for long periods of time and thus be able to refer experienced potential subjects. After making these contacts to sixteen officers, I received eight e-mail responses and five referrals. ${ }^{84}$ Of these five referrals, two subjects agreed to interviews, for a response rate of $40 \%$. As with all subjects, these persons

\footnotetext{
${ }^{84}$ In order to protect subject confidentiality, I never communicated to any of the FBA officers whether their referral resulted in an interview. Furthermore, specific quotes and results do not distinguish subjects based upon contact method.
} 
were also provided both written and verbal informed consent of their participation in the research.

Finally, at the conclusion of each interview, I asked all subjects if there was any other person in their district that he/she believed could answer the interview questions or otherwise be beneficial to this research effort. This strategy, known as "snowball sampling" is predicated on the notion that persons with knowledge regarding a particular subject will be able to refer researchers to other knowledgeable persons on the subject (Suchman and Cahill 1996). This technique is especially fruitful in the area of federal criminal sentencing, where despite the large amount of criminal cases adjudicated, there are often only a small number of "insider" attorneys within each district (Narduli 1986).

One critique of snowball sampling is that it might lead to overrepresentation of a single network of contacts, who share the same perspective (Bleich and Pekkanen 2013). Thus I made clear to all respondents in my referral requests that I sought to get a wide range of interview subjects and that I would welcome opposing or different perspectives from themselves. The snowball sampling method led to sixteen referrals, and ultimately eleven subjects, with an expectedly higher response rate of $69 \%$. The overall response rate for all three methods of contact was $45 \%$.

\section{Conducting the Interview \& Coding Responses}

When speaking with subjects, I used semi-structured interview techniques (Leech, et. al. 2013). I thus began with a list of prepared questions ${ }^{85}$, but left most questions open-ended for subjects to answer them as they saw fit. I first asked general questions to gain insight into the inputs of district court judges' sentencing decisions. I also asked general probing questions,

\footnotetext{
${ }^{85}$ See Appendix A for a list of the prepared questions.
} 
asking respondents to explain why they believed district court judges generally choose to apply Guideline-recommended sentences or issue below-Guideline sentences. I asked similar general questions regarding whether and why the subjects believed judges approached sentencing differently over time, and what factors account for differences in judges in their sentencing behavior.

After subjects gave general responses, I asked more specific yes/no questions regarding potential influences ${ }^{86}$ of judicial sentencing behavior in the aggregate. For example, "generally speaking, do you believe the political party of the sentencing judge (based upon the political party of the appointing US President) affects departure decisions? If so, in what way?" It is the responses to these questions, I utilized for testing competing theoretical perspectives

When coding results to specific areas of inquiry, I divided responses into three categories: “agreement", "qualified agreement" or "qualified disagreement/disagreement." This coding procedure became necessary as many respondents believed that certain factors were influential on judicial sentencing decisions, but this influence were either secondary or conditional. Examples of qualified agreement statements would be answers, such as "yes, for some judges that matters" or "yes, in certain cases" or "yes, I think that plays some role." Once the "qualified

\footnotetext{
${ }^{86}$ Notably, some interview researchers have critiqued questions intended to uncover the general influences on policymaker behavior as too abstract and not necessarily likely to lead to valid and reliable results (Kingdon 1981; Hall and Beckman 2013). The nature of the critique levied is that people do poorly at explaining why they do the things they do or whether certain factors influence behavior, and it is better to ask respondents concrete questions about specific results. However, as exemplified by the interview-research for MacDonald (2007) and Baumgartner, et. al. (2009), when the substance of responses includes specific descriptions and examples of the issue being probed, there is strong evidence that subjects' yes/no responses to sources have influence have some facial validity. As will be shown in the results below, subjects' responses in the present study generally included this high level of specificity. When subjects were asked about specific sources of influences on judicial sentencing policy, they would often relay a pertinent anecdote or cite specific reasons as to why a factor was, or was not, important. Furthermore, based on their responses, most subjects seemed to have previously considered whether inquired sources of influence were relevant, providing further evidence that the subjects understood how sentencing decisions were made broadly. Thus, in spite of critiques of questions on behavioral inputs, both the judge and non-judge subjects demonstrated clear ability to competently opine on these sources of influence.
} 
agreement" category was added, it was fairly easy to categorize responses into one of the three categories.

In reporting results, I incorporate both quotations from individual subjects and descriptive statistics of aggregate responses to specific questions. The quotations are the primary focus of the analysis, as they provide a more rich understanding of the thought process of district court judges in making sentencing decisions. However, the use of descriptive statistics compliments the quotes and allows for facial comparisons of different theories of judicial sentencing behavior. Moreover, the use of the statistics alleviates qualitative research concerns of "cherry picked" quotes that conform to the researcher's theoretical perspective (Bleich and Pekkanen 2013).

\section{Results}

\section{The Subjects}

In total, I conducted nineteen approximately hour-long interviews with subjects. Each district yielded at least four subjects and no district yielded more than six subjects. Some general information regarding the subjects is set forth in Table 2 below.

\section{[Table 2 about here]}

As can be gleaned from Table 2, the pool of subject was extremely experienced. The median subject had twenty four years of experience in federal sentencing practice in the district and no subject has less than thirteen years of experience. In addition to this gross measure of experience, qualitatively, all nineteen interview subjects characterized themselves as "very familiar" with federal sentencing practice in their district.

As shown in the second row of Table 2, the interview subjects included six judges or former judges and thirteen attorneys. Also of note there were seven subjects who practiced only criminal-defense, two subjects working the U.S. Attorney's Office, and four "hybrid" attorneys 
who formerly worked in the U.S. Attorney's Office but were now private practice defense attorneys. Although unfortunate, this disparity of more defense attorneys was expected as the U.S. Attorney's Office is a hierarchical institution with published policies and opinions with respect to federal sentencing (See. e.g. Holder 2010). Thus, U.S. attorneys and assistant U.S. attorneys were expected to be more reticent about expressing personal opinions that may diverge from these official positions. ${ }^{87}$ A mitigating factor that helps alleviate any concern of a defensebiased perspective is the four hybrid subjects who are former Assistant U.S. Attorneys. Thus, six of the thirteen attorney interview subjects at least have some experience prosecuting cases for the government.

Finally, the last two rows of Table 2 illustrate another major caveat to the results of this research. The subject pool is disproportionately white and male. There are only three females, two African Americans, and no Hispanic Americans in the subject pool. The pool is particularly disproportionate as to gender (16\% female), when considering the legal profession as a whole. Based on the most recently available data, $34 \%$ of all lawyers and $33 \%$ of federal district court judges are female (ABA 2014). Overall response rates were only slightly lower among women (30\% vs. $45 \%$ ), but the real source of the gender disproportionality appears to be in the lack of referrals to female subjects through the snowball sampling method (13\% of referrals). This fact perhaps underscores concerns that the snowball sampling method leads to overrepresentation of a single, interconnected social group (Martin 2013).

However, the gender disparity in the subject pool might also be partially explained by the requirement that subjects have at least ten years of experience in federal sentencing. Examining,

\footnotetext{
${ }^{87}$ As set forth below, all results reported herein reflect the personal opinion of the interview subject and the interview subject alone. These opinions do not to reflect the official position or opinion of any other person, office, institution, or other entity.
} 
past data, the proportion of both practicing female attorneys and female district judges in $2003^{88}$ was much greater aligned with the proportion of the females in the subject pool (ABA 2003). Regardless of the causes of the disparity, interpretations of these results should bear in mind potential biases from a disproportionately white, male perspective.

\section{Individual Case/Offender Characteristics}

As will be discussed throughout these results, there was very little consensus among the interview-subjects as to what factors influence district court judges' sentencing. There was similarly little consensus as to what accounted for the two "puzzles" of sentencing identified previously, namely: the continued increase in below-Guideline sentences after 2005 when the Guidelines were declared "advisory ("Puzzle \#1”); and interdistrict variation in judicial application of the Guidelines ("Puzzle \#2"). Thus, broad agreement amongst the interview subjects was the exception, rather than the norm. However, there were certain aspects of federal sentencing policy the vast majority of respondents agreed on and therefore merit some discussion.

First, most respondents cited individual case facts as the most important, or one of the most important factors, influencing a judge's sentencing decision. Indeed, when asked the general question of why judges choose to issue sentences below the Guideline-recommended range, $89 \%$ of respondents cited factors specific to each individual case. Examples of these casespecific facts include the criminal history of the offender, whether violence was involved in the offense, and whether the offender had familial responsibilities.

This finding that individual, case-specific factors are crucial to determining sentencing outcomes is not at all surprising and is consistent with past sentencing research (Fischman and Schanzenbach 2012; Ulmer, et. al. 2011; Mustard 2001). I place less emphasis on these

\footnotetext{
${ }^{88}$ In 2003, 29\% of all lawyers and $16.1 \%$ of all judges were female (ABA 2003).
} 
individual-case characteristics not because they are unimportant, but because many of these factors are incorporated into the framework of the Sentencing Guidelines (e.g. whether violence was involved, the criminal history of the offender, the offender's acceptance of responsibility). Thus, unless offender or offense characteristics have changed drastically over time, which does not appear to be the case (USSC 1995-2014), these factors are very unlikely to be the cause of the increasing trend of more lenient sentences over time ("Puzzle \#1").

However, some individual case characteristics, particularly offender traits such as the race of the offenders, may partially explain interdistrict variation in judges' sentencing behavior (“Puzzle \#2). There is strong evidence African Americans and Hispanic offenders ultimately receive harsher sentences than similarly situated White offenders (USSC 2012; Mustard 2001). Thus, to the extent district court judges hold these racial and ethnic biases, and levels of bias vary throughout the country, it is possible these biases help explain differing sentencing behavior among district court judges. Despite this possibility, recent research has largely rejected this theory and found that racial disparities in sentencing outcomes are largely driven by prosecutorial behavior rather than district court judge sentencing decisions (Hofer 2013; Fischman and Schanzenbach 2012; Rehavi and Starr 2012).

This finding was supported by the interview subjects. When asked whether racial biases impacted district court judges' sentencing decisions in the aggregate, $74 \%$ disagreed. A subset of the subjects who agreed dipartites existed argued that some district court judges were subject to "unconscious biases ${ }^{89}$ " that resulted in fewer below-Guideline sentences for African Americans in the aggregate. However, the subjects ${ }^{90}$ responses in total support recent findings

\footnotetext{
${ }^{89}$ Interview No. 4, August 20, 2015; Interview No. 19 January 20, 2016.

${ }^{90}$ We should bear in mind, however, that 17 of 19 subjects were White, which could partially explain unwillingness to acknowledge racial factors.
} 
that district court judges' sentencing decisions are not the cause of the clear racial disparities that exist in federal sentencing outcomes (See Hofer 2013; Fischman and Schanzenbach 2012; Rehavi and Starr 2012; Mustard 2001).

On the other hand, subjects were much more willing to agree that the gender of the offender affected judges' sentencing decisions. 79\% of all respondents and $80 \%$ of judges/former judges admitted that, in the aggregate, women were more likely to receive a below-Guideline departure. ${ }^{91}$ Taken together, the subjects' responses suggest possibly that gender but not race is a component of district court judges sentencing decisions. Another possibility, however, is that subjects responses merely reflect the psychological propensity for people to be more willing to accept and admit gender biases as opposed to racial biases (See Czopp, et. al. 2003).

\section{Judicial Discretion}

Moving beyond individual-level factors, another area of consensus amongst subjects was their policy agreement with the ruling in the 2005 case of US v. Booker that rendered the Guidelines advisory. All but one subject (94\%) expressed agreement with Booker and preferred a system of "advisory" Guidelines to "mandatory" Guidelines. Indeed, only about half of subjects supported the existence of the Guidelines at all. As to the proscribed sentence ranges in the Guidelines themselves, one subject summarized the general sentiment of the subjects by stating, "as a general rule, the Guidelines are perhaps a little too punitive." 92 While U.S. Attorney and judges/former judge subjects were less likely to be critical of the Guidelines than defense attorneys, many of them cited certain overly punitive Guidelines as grounds for why they agreed

\footnotetext{
${ }^{91}$ Although it should be noted that subjects often explained these disparities were warranted due to general lower levels of criminal participation by female offenders and/or less severe criminal histories.

${ }^{92}$ Interview No. 11, December 7, 2015.
} 
with Booker. Not a single subject suggested the Guidelines were not punitive enough in general. Nor did any subject give any example or anecdote of a Guideline sentence for a particular crime that provided for insufficient penalties.

These results are important, because they indicate that there is some consensus in the legal community that the Guidelines are too punitive. This is not a surprising finding, and is consistent with past surveys of Guideline criticisms in the legal community (Hofer and Allenbaugh 2003). The finding is, however, a necessary condition of the reputational aspect of my theoretical perspective, which argues that judges' reduced adherence to the Guidelines over time is partially explained by the legal-community's growing hostility to harsh, determinant sentences. If we observed substantial disagreement regarding the wisdom of Booker or the punitive nature of the Guidelines, it would be more difficult to claim that the legal community was influencing judges in a less punitive direction. The fact that the subjects almost uniformly expressed support for discretionary sentencing means that a theory of legal-community influence retains plausibility.

\section{Differences in Judges}

A final point of consensus by the interview subjects was simply that different judges look to different factors when making their sentencing decisions. The most common qualifier amongst subjects in their responses to whether certain factors were influential was "for some judges." In other words, despite question framing using terminology such as "in general" subjects were hesitant to lump all judges into one category and stressed the variability of judges. One interview subject described judicial individuality by stating each judge has a "sentencing persona" that he/she takes on, and the differences in these personas are clearly observable in 
sentencing outcomes. ${ }^{93}$ This finding of variability amongst district court judges will be discussed in greater detail below, but as an initial matter, it clearly calls into question any parsimonious and simplistic explanations of how district court judges sentence offenders.

\section{Local/Contextual Influence}

Before analyzing the subjects responses to specific questions on potential sources of influence, it is prudent to get a senses of whether subjects agreed in general that judges could be influenced by local contextual factors. Responses to this general question serve as a test of facial validity of my theoretical perspective. If a strong majority of experienced subjects in federal sentencing do not believe that district court judges responded to contextual influences in sentencing decisions, it would be difficult to sustain support for the argument that these factors are important.

Subjects, however, were generally supportive of the notion of local contextual influence on sentencing decisions. 15 of 19 subjects (79\%) expressed agreement or qualified agreement that the local environment impacted district court sentencing decisions. As will be discussed in greater detail below, there was much greater disagreement amongst subjects regarding the source(s) or reasons for this contextual influence. But it is noteworthy that several subjects believed that local, contextual factors played at least some role in shaping sentencing outcomes.

Table 3 presents descriptive statistics of subject agreement/disagreement with the four queried sources of local contextual influence. As can be gleaned from Table 3, there was little agreement among respondents as to whether these individual factors influence sentencing decisions. None of the potential sources of influence was broadly supported by a large majority of subjects. On the other hand, each variable had its fair share of proponents.

\footnotetext{
${ }^{93}$ Interview No. 14, August 6, 2015.
} 


\section{[Table 3 about here]}

As can also be seen from Table 3, there is fairly little difference in the levels of support for each of the factors verified. Subjects were generally more likely to express unqualified agreement that the "reputational" variables of local legal community or public impacted judges than the "objective conditions" variables of crime rates and incarceration rates. But in general, each potential source of influence was split fairly evenly between supporters and detractors.

This leads to the pertinent question of whether it was all the same subjects supporting the importance of the various contextual influences. This was not the case. In addition to the aforementioned result of $79 \%$ of subjects supporting the notion of general environmental influences, $89 \%$ of subjects (17 of 19) agreed that at least one of the above four variables was affecting judges. Thus, while there were two subjects in the sample who denied the impact of contextual factors both in general and when asked specifically, a significant majority of respondents agreed that at least one these influences had some impact on sentencing decisions.

\section{a) Local Legal Community Opinion}

As shown by Table 3 , subjects disagreed whether judges' ultimate sentencing decisions were impacted by the opinion of the local legal community on sentencing policy. On the one hand, many subjects expressed strong agreement that judges' in their district were very much intune with the local legal community. One such subject stated as follows:

[This district] has one of the most active federal bar organizations in the country. The Federal Bar consistently has the judges participate in events, come to lunches, head discussion groups, host book conferences. [Judges] are very in tune of what is going on in the legal community. ${ }^{94}$

Note, however, that the above quote does not specify whether this subject believes being "in tune" with the legal community resulted in any change in judges' criminal sentencing

\footnotetext{
${ }^{94}$ Interview No. 3, August 6, 2015.
} 
behavior. When asked this follow up, the subject responded, "I do think judges take into consideration what is happening in [our district] when actually imposing sentences. It seeps in. ${ }^{95}$

Two other subjects reported that differences in local legal cultures were likely driving any interdistrict variation in sentencing outcomes. One of said subjects argued there were "cultures of practice ${ }^{96 "}$ related to sentencing within each district's legal community, and judges were a part of these cultures. The other subject stated that to the extent there remained sentencing disparity across district this was probably due to different legal cultures. ${ }^{97}$

These subjects' perspectives are supportive of my own theory that as members of a local legal community, judges' criminal sentencing will reflect that community. They are also consistent with the findings of Ulmer (2005) and Lynch and Omori (2014) that different legal cultures ultimately lead to different sentencing outcomes in different districts in similar cases. However it should be noted, that not all subjects agreed the local legal community affected judicial sentencing behavior.

One subject stated, "I think judges are actually more sensitive to other judges in other jurisdictions. They don’t care what the local Bar thinks." 98 One former district court judge acknowledged that judges' are concerned about their reputation amongst the local legal community, but denied that this concern had a tangible impact on their sentencing decisions. ${ }^{99}$ This former judge argued that judicial reputations in the legal community were linked to perceptions of fairness and collegiality rather than the substance of the judges' decisions.

\footnotetext{
${ }^{95}$ Interview No. 3, August 6, 2015.

${ }^{96}$ Interview No. 7., October 20, 2015.

${ }^{97}$ Interview No. 10, November 11, 2015.

${ }^{98}$ Interview No. 9, November 6, 2015.

${ }^{99}$ Interview No. 12, January 21, 2016.
} 
Notably, however, many attorney subjects belied this opinion and made normative judgments on the quality of judges in their district based solely on their punitive tendencies in sentencing. ${ }^{100}$

Taken together, these results suggest that there is little consensus among actors experienced in federal sentencing on the impact of the local legal community on judges' decisions. Certain subjects explained how legal communities shape judges' preferences, while other subjects were more prone to view judges as uncaring towards local practices and opinions. However, the fact remains that there is substantial interdistrict variation in how strictly judges are applying the Guidelines (USSC 1995-2014). This variation is consistent across years and cannot merely be the product of random chance (Ulmer 2005). Thus, to the extent interdistrict variation is not explained by differing local legal cultures, it must be explained either by some other district-specific factors.

\section{b) Local Public Opinion}

As shown by Table 3, there was slightly less agreement amongst subjects that sentencing behavior was impacted by the public's opinion on crime and punishment, as opposed to the opinion of legal elites. One subject described the difference in his own district as follows, "Judges are less influenced by the culture of the city or state. They are more influenced by the courthouse community. [This District] is pretty progressive on criminal justice issues, but the courthouse community is pretty dogmatic." ${ }^{\prime 101}$

Despite this opinion, one former judge was happy to admit that the public's view impacted his decisions:

\footnotetext{
${ }^{100}$ Interview No. 1, August 4, 2015; Interview No. 3, August 6, 2015; Interview No. 19, January 26, 2015.

${ }^{101}$ Interview No. 1, August 4, 2015
} 
I agree [that public views regarding crime influence judges]. Judges are part of the community. We hear things and are very sensitive of the public. We read the news. When we feel the public is outraged, we understand that. At the same time, if there is perception that someone has been done an injustice, we are also mindful of that. ${ }^{102}$

This statement perhaps reflects the strongest anecdote for how judges' sentencing behavior can be influenced by the public, especially it seems, when the public is paying particular attention to crime or a particular offense. Interestingly, this subject was not alone in volunteering the impact media coverage of crime might have on judges. Another defense attorney subject when asked the question on public opinion influence, agreed that it was influential and then gave an anecdote of how the judge justified his sentence:

Yes [the public influences judges' sentencing], because [judges] live in the community, most often. They read the papers, and they watch the news, and they see the pain in the community. I just did a case that involved a weapon in federal court and the judge slammed him. He went on a little speech and said 'all you have to do is listen to the news or read the paper to know that guns are illness in our society, and you have to figure out a way to stop it. ${ }^{103}$

While this anecdote may be more indicative of media influence and/or crime rate influence on judges than it is demonstrative of direct public influence, it clearly shows how judges' connection to their communities can be important.

Yet another subject conditioned public influence on judicial sentencing decisions to "high publicity cases." These responses by the subjects regarding media attention and publicity highlight an important issue regarding the mechanism by which the public may influence sentencing decisions. If judges are concerned about their reputation in their community regarding sentencing, it is very likely that there sentencing behavior may only be altered or adjusted in cases of high media attention. This theory could be tested in future research by

\footnotetext{
102 Interview No. 17, December 18, 2015.

${ }^{103}$ Interview No. 2, August 19, 2015
} 
examining sentencing decisions by federal district courts in similar cases with varying levels of publicity.

A related issue regarding public influence on the judiciary is the debate between scholars like Mishler and Sheehan (1996) and Casillas, et. al. (2011) who argue that the public can directly influence the judiciary, and Segal and Spaeth (2002) who instead claim that any public influence is likely to be merely "indirect" as judges are members of the public. As discussed above, some subjects supported the notion of indirect influence by describing judges as "people too" whose opinions changed with changing conditions. However, it is noteworthy that at least the quote of the former judge above seems to acknowledge some degree of direct influence (e.g. "we are sensitive to that"). The debate is difficult to untangle and certainly not the focus of the present study. Yet given recent evidence from Casillas, et. al. (2011), Nicholson-Crotty, et. al (2009), it is worth exploring further whether or not the public directly influence district court judges' sentencing.

Finally, notwithstanding the views of several subjects, it is worth reiterating that a slight majority of subjects (10 of 18) did not agree public views impact judges' sentencing decisions in general. As with many sources of influence examined, the results suggest a lack of consensus and also that different judges pay attention to different inputs in their sentencing decisions. While some judges surely are concerned with their reputation in both the broader community and

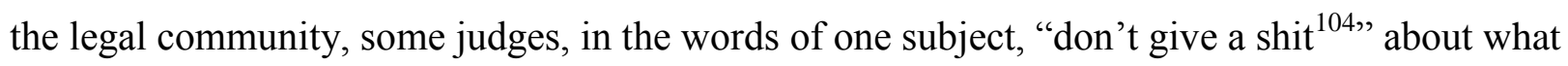
anybody else thinks.

\section{c) Incarceration Rates}

As shown by Table 3 , results related to the incarceration rate were mixed. The relatively high number of "qualified agreement" responses for this variable also suggests that many

\footnotetext{
${ }^{104}$ Interview No 11, December 7, 2015.
} 
subjects believed the impact of high levels of incarceration on judicial sentencing was conditional on other factors. One such condition might relate to the judges' ideological preferences. One subject stated,

It's becoming more and more obvious we incarcerate more people in this country than anywhere in the world, and it's not accomplishing anything. But [the effect of the incarceration rate on judges] depends on the ideological spectrum. More conservative judges, still think 'lock em up. ${ }^{\text {, }} 105$

On the one hand, this view is consistent with my perspective of increased judicial sensitivity to the social problem of incarceration. However, it is also supportive of the Fischman and Schanzenbach (2011) and Epstein, et. al. (2013) perspective that judges' personal partisan/ideological preferences are key to determining district judge sentencing behavior. Future examinations of the potential effect incarceration rates have on judges' sentencing behavior should exhibit more closely whether liberal/Democratic judges might be more influenced by the incarceration problem than conservative/Republican judges.

Another interesting aspect of the subjects' responses to questions regarding incarceration was its temporal nature. Specifically, many subjects described how only recently did they notice judges becoming sensitive to the incarceration issue. One subject stated "more recently, judges have become sensitive to [incarceration rates]. Historically, I don't think they have, though I don't think judges cared about this at all."106 This sentiment was echoed by another subject stating, "A number of judges have been increasingly sensitive to [incarceration rates]. They are seeing that locking these people up for a long time is not doing a thing."107

The temporal nature of the effect of incarceration is further exemplified by the comments of one federal district court judge describing his evolving views on sentencing,

\footnotetext{
${ }^{105}$ Interview No. 2, August 19, 2015

${ }^{106}$ Interview No. 9, November 6, 2015

${ }^{107}$ Interview No. 11, December 7, 2015.
} 
The longer I've been a judge, the more hostile I am to the system. My attitude towards long sentences has significantly changed over time. I'm more conscious of the lack of social utility of long sentences. If you want to really teach [offenders] a lesson, you should do public shaming or lashes. That has social utility....not just sending them to prison and forgetting about them. There is no deterrent effect. $^{108}$

This statement is somewhat striking in that it evidences a federal district judge supporting the somewhat arcane form of punishment of public shaming. But the more relevant point is that this judge is suggesting he engaged in some form of policy evaluation that altered his sentencing preferences. This judge's self-described change was apparently not aberrant. Another attorney interview subject described a judge who had previously been an "unsympathetic former prosecutor who put a lot of people in jail for a really long time." 109 However the judge "has now seen the drug war is unwinnable" and "has become a much more lenient sentencer."

These findings are supportive of my argument that judges' views of good policy, and thus their behavior, can change over time due to changing conditions (See Kritzer 1978). Based upon the above two quotations, both of these district court judges used to believe that long sentences were "good policy" but over the course of his years on the bench, they changed courses and began to sentence offenders more leniently. The temporal aspect of the effect may help explain why we continue to see lower sentences and more Guideline departures a decade after Booker was decided (“Puzzle \#1").

However, it should not be overlooked that many subjects believed that district court judges were not concerned with the broader social problem of incarceration. One former district court judge described the lack of influence of incarceration rates as based on the role of judges, "judges have an obligation to impose a sentence within a framework, in which the definition of

\footnotetext{
${ }^{108}$ Interview No. 14, August 6, 2015.

${ }^{109}$ Interview No. 11, December 7, 2015.
} 
crime and sentencing range are dictated by the legislative branch of the government."110 Another subject suggested that incarceration rates would likely influence judges in the future if they became "part of the conversation" in the legal community, but in his view that had not yet occurred in his district. Other subjects disagreed, and one assistant U.S. attorney subject lamented that defense attorneys raise the issue of high incarceration "all the time" at sentencing hearings, and that some judges have agreed with these attorneys and have justified lower sentences by stating "the jails are overcrowded." 111

When viewed together, the mixed and conditional results of the effect of the incarceration rate on sentencing behavior, likely reflect differences in judges. While many judges might see incarceration as a social problem they can fix, some judges might restrain themselves from exercising this role (Gibson 1978). Relatedly, some more conservative judges may not see incarceration, in and of itself, as a problem at all and might be pre-disposed to agree with Guideline sentences (Fischman and Schanzenbach 2011). Still, the responses in total suggest that at least some judges under some conditions pay heed to social factors such as incarceration when making their sentencing decisions.

\section{d) Crime Rates}

The second "objective condition" the subjects were asked about were crime rates. The logic underlying crime rate influence on sentencing behavior is that higher crime will prod judges to punish and deter criminal offenders through longer sentences. There is also some evidence for this phenomenon found by Ulmer and Bradley (2006) and Gibson (1980) with respect to state-elected judges, in addition to various models presented in Chapter 3 of this dissertation.

\footnotetext{
${ }^{110}$ Interview No. 13, December 11, 2015.

${ }^{111}$ Interview No. 3, August 6, 2015
} 
The results from the subjects' responses on crime rate influence were mixed. As shown in Table 3, the same percentage of respondents $(53 \%)$ who believed incarceration rates were impacting sentencing decisions believed crime rates were impacting sentencing behavior. ${ }^{112}$ One notable difference in the responses to the two objective variables is that more subjects were more willing to give unqualified support for the notion that crime rates affect sentencing decisions. Curiously, however, the relatively unconditional support for the impact of crime rates on sentencing decisions manifested itself in several different ways.

One U.S. attorney agreed wholeheartedly that high crime rates resulted in harsher sentences by judges, and cheerfully attributed this judicial attention to the crime rate as the result of the U.S. Attorney's Office "pushing” the issue of societal crime into the judicial focus. ${ }^{113}$ One defense attorney similarly agreed judges seek to address problems of higher crime through longer sentences. Not surprisingly, however, this defense attorney had a different view on whether judges should be doing this. He stated, "some judges foolishly believe the general deterrence argument has some value."114

This reference to "general deterrence" is the notion that longer sentences will deter future individuals from engaging in similar behavior. The value of general deterrence is a largely empirical question outside the purview of this research. However, the importance of the concept to the present research is that this subject's comments, implies that some judges do believe in general deterrence. ${ }^{115}$ This suggests some judges view sentencing criminals as a task that goes

\footnotetext{
${ }^{112}$ However, as noted above, these subjects were not all overlapping. Certain subjects believed the crime rate was influential but not the incarceration rate, and vice versa.

${ }^{113}$ Interview No. 3, August 6, 2015.

${ }^{114}$ Interview No. 19 January 20, 2016.

${ }^{115}$ It is also noteworthy, that deterrence is one of the "legal factors" judges are instructed to consider when imposing a sentence" listed in 18 USC $\S 3553$.
} 
beyond arriving at individually just sentences, and consider their potential ability to control future crimes.

On the other hand, one unexpected finding from subjects responding to questions on the crime rate, was that some subjects expressed opinions that higher crime rates might actually influence judges in a less punitive direction. One district judge acknowledged this possibility with the following paraphrased ${ }^{116}$ statement related to drug crime in particular:

There is so much drug crime, it must have an influence. But it could work either way. One way of looking at it would be judges in high crime areas don't see the point of incarcerating harshly, because the drug war is unwinnable. But another way of looking at it is judges in these areas might sentence criminals more harshly, because drugs are driving out business, and they want to punish and deter perpetrators. ${ }^{17}$

Thus, this district judge suggested that high crime might pull judges in opposite directions. This subject was not alone in proposing this alternative theory of higher crime being associated with more lenient sentences. Indeed, two other subjects went further and argued more forcefully that judges living in low-crime rural areas were less familiar with serious crime, and thus were more prone to treat offenders as deviants and punish them harshly. ${ }^{118}$ Notably, while these alternative theories for crime rate influence differ from my expectation, they are consistent with my broader theoretical perspective of contextual influence. In other words, many subjects agreed that the crime conditions in judges' communities will shape their sentencing behavior.

In summary, the crime-rate results were the very definition of mixed. While a majority of subjects agreed the crime rates were influential on sentences in some circumstances, a

\footnotetext{
${ }^{116}$ This subject declined to be recorded, so the paraphrased statement is reproduced from the researcher's notes.

${ }^{117}$ Interview No. 13, December 11, 2015.

${ }^{118}$ Interview No. 16 January 20, 2016; Interview No. 17, December 18, 2015
} 
substantial minority of subjects saw no impact. Moreover, those who did see an influence of the crime rate disagreed about the direction of the effect.

\section{Alternative Theoretical Perspectives}

\section{a) Partisan/Ideological Factors}

In addition to probing potential exogenous contextual influences on district court sentencing decisions, I also asked subjects regarding alternative sources of influence. One such alternative theoretical perspective is that judges' personal partisanship or ideology affects whether they tend to issue relatively more or less punitive sentences. (Epstein, et. al. 2013; Fischman and Schanzenbach 2012). However, the pool of subjects generally disagreed that district court judges' personal partisan or ideological preferences impacted their sentencing. More precisely, the percentages of subjects who agreed ${ }^{119}$ district court judges' party or ideology influenced their sentences were only $26 \%$ and $37 \%$ respectively.

In their responses to these questions, many subjects volunteered specific examples. One defense attorney stated, "probably the judge you want the most in my district is a Republican appointee." 120 Another district court judge subject stated "political philosophy doesn't always translate to criminal sentencing" and explained that fiscal conservatives are now probably less supportive of longer sentences. ${ }^{121}$ Similarly, other subjects described personal partisan or ideological factors as "not accounting for a whole lot" of why judges approach sentencing differently. ${ }^{122}$

Indeed, somewhat surprisingly, a lower proportion of subjects expressed general agreement that either judges' individual partisanship or ideology impacted sentencing outcomes

\footnotetext{
${ }^{119}$ Unqualified Agreement plus Qualified Agreement.

${ }^{120}$ Interview No. 4 August 20, 2015.

${ }^{121}$ Interview No. 8 November 6, 2015.

${ }^{122}$ Interview No. 11 December 7, 2015.
} 
than any of the four exogenous factors discussed above. Given the legal community's reluctance to admit the impact of partisan/ideological factors on outcomes even in the face of clear evidence to the contrary (See e.g. Spaeth and Segal 1999), perhaps we should view subjects' general lack of agreement on the impact of partisan or ideologically factors with some skepticism. However, given the relative lack of attention paid to contextual factors in past research, it is still an important finding that subjects found partisan/ideological factors to be relatively less important.

\section{b) Prosecutorial/Systemic Factors}

On the other hand, consistent with recent studies (Lynch and Omori 2015; Ulmer 2005), several subjects volunteered that the prosecutorial practices of district U.S. Attorney's Offices could ultimately impact sentences. When subjects were asked to elaborate on this point, many cited the obvious fact that if the offender was convicted of an offense with the mandatory minimum, then district court judges were unable to unilaterally ${ }^{123}$ sentence the offender to a lower sentence. When questioned further regarding cases where judges do have discretion to implement below-Guideline sentences, many subjects still believed that the prosecution's practices could impact judges.

One defense attorney discussed how defense attorneys were merely "reactors" to U.S. attorneys. ${ }^{124}$ In other words, the parameters of a potential sentence are initially defined by the U.S. attorney's argument for why a Guideline sentence is appropriate. Thus, the likelihood of judges granting a below-Guideline sentence was greatly dependent on whether and how vigorously U.S. Attorneys initially sought Guideline sentences, even in non-mandatory minimum cases.

\footnotetext{
${ }^{123}$ Offenders can be sentenced below mandatory minimum sentences with the agreement of the U.S. Attorney in certain circumstances, such as providing "substantial assistance" to law enforcement (See U.S. Sentencing Guidelines, 2015, 5K1.1).

${ }^{124}$ Interview No. 7., October 20, 2015.
} 
This finding of the importance of prosecutorial practices is consistent with previous findings that individual districts have varying prosecutorial practices which impact sentencing practice and help explain interdistrict variation in outcomes (Lynch and Omori 2014; Wu and Spohn 2010; Ulmer 2005). The finding also serves as a reminder of the constrained power of district court judges within the federal sentencing system. While ultimate sentencing decisions often do rest with district court judges, these judges still must operate within sentencing institutions and are not free to simply impose their preferred sentences.

\section{c) Increased Hostility towards Guideline Sentences: Judicial Habit}

Regardless of any district-specific prosecutorial practices, the puzzle of ever-decreasing Guideline adherence and shorter sentences since Booker ("Puzzle \#1) suggests that there has been a more national revolt by district court judges against relatively punitive, Guideline-range sentences. Existing explanations for this phenomenon were simply that district court judges were "getting used" to the authority granted to them under Booker (Epstein, et. al. 2013). Under this theory, even after Booker, district judges were simply accustomed to granting Guideline sentences and continued to do so in the years following Booker. As judges began realizing their sentences would not be overturned on appeal from 2006-2015, they gradually imposed more below-Guideline sentences.

As noted above, I was initially skeptical that district court judges would take such a long time to react to the Booker decision. The alternative explanation I posited and inquired to subjects was that district court judges became increasingly aware of the high costs of incarceration and were responding to the failure of the policy of longer Guideline sentences. Indeed, as discussed in detail above, many subjects expressed support for this explanation and argued that judges were becoming more and more acceptant of the argument that long sentences 
for certain offenses were unjust and that many were willing to use their power to correct this inequity.

However, and contrary to my own expectations, many subjects also expressed support for the predominant "habit" theory. One subject described the post-Booker landscape as follows:

Booker began the revolution, but it took a little while for it to kick in. Humans are creatures of habit. It's also very judge dependent. Judges have different attitudes about sentencing. Some see it as part of their job to use their discretion. Others are more rule-bound and creatures of habit. ${ }^{125}$

Another subject described the lack of an immediate surge in below-Guideline sentences after Booker as follows:

Booker was significant. It would be wrong to underestimate Booker. But judges felt more constrained right after Booker. As they became more experienced and other cases came down, the judges recognized their own authority. ${ }^{126}$

Thus, contrary to my expectations, many subjects with years of sentencing experience agreed that the incremental increase in proportions of below Guideline sentences was due to a gradual recognition by judges that they had the power to issue these types of sentences. Still, I argue this finding should be read in tandem, rather than in opposition, with many subjects' acknowledgment of judicial awareness to the incarceration problem and legal elites' hostility towards Guideline sentences. The two perspectives are not mutually exclusive and expanded inquiries into their relative explanatory weight, perhaps through a comparison of judges appointed pre-Booker and post-Booker, would advance understandings of why and how judges adapt to dramatic changes in legal policy.

\footnotetext{
${ }^{125}$ Interview No. 5. September 21, 2015.

${ }^{126}$ Interview No. 9, November 6, 2015.
} 


\section{Discussion}

This study, while initial and exploratory, adds insight into how federal district court judges render criminal sentencing decisions. The opinions of extremely experienced actors in federal sentencing presented in this research, demonstrate the strengths and shortcomings of both my own argument of local exogenous influence and alternative perspectives. In sum, there are several general propositions that can be derived from the results of the interviews.

First, there is strong evidence that some judges are sensitive to certain exogenous local contextual factors. Four factors were studied as part of this research: local legal community opinion, public opinion, the incarceration rate, and the crime rate. The results as to all four factors were clearly mixed. For each of the variables studied, more than one-third of subjects but less than two-thirds of subjects agreed that the factor affects district judges' sentencing. However, and importantly, only two of the nineteen interview subjects believed that these contextual factors were all generally unimportant to judges' ultimate sentencing decisions.

This general finding is important, as it supports the notion that where/when judges make decisions affects those judges' decisions. While this general point might seem uncontroversial, the specific sources of contextual influence on sentencing have been understudied in past federal criminal sentencing research. There is no doubt however, based on the responses of some former and current district court judges themselves, that certain judges take these matters into account when sentencing individual offenders. This important finding is consistent with Ulmer (2005) and Lynch and Omori (2014) suggesting that district court judges, while operating in a national level system, cannot be compelled into behaving similarly by legal changes at the national level.

Not to overstate the results, the subjects' general acknowledgement of the importance of contextual factors, but their lack of consensus on the importance of each individual factor 
suggests that more empirical testing is needed regarding contextual influence. As discussed in the Results sections, it is quite possible that some inputs, such as the crime rate and public opinion, are conditional or contingent on other factors, such as media attention. Future studies could address many of these possible conditions to help determine when contextual factors are likely to be most important.

The lack of consensus among interview subjects on specific sources of influence is likely also the product of the second important conclusion of this study: differences in judges. Nearly all of the subjects went out of their way to emphasize how much variation there was in how district judges approached sentencing, even within the same district. In the words of one subject, "every judge is a unique individual. Their personal attitudes will always inform their sentencing decisions." $" 127$

When probed on the potential sources of these differences in judges, subjects were hesitant to give simple and specific answers (e.g. partisanship, ideology, sensitivity to the community) and often relied on generalizations such as different "world-view." "28 When pressed further on these differences, several subjects cited many different variables including, upbringing, education, and prior profession. In describing why contextual factors may influence some judges but not others, some subjects suggested that its impact depended on whether judges saw their judicial role as limited to applying the legal framework to the facts or each case or as active participants in public policy.

The upshot of these varied responses is that students of judicial behavior must pay more attention to variation amongst judges. While it is certainly valuable to make parsimonious generalizations about judicial behavior, much individual judicial behavior can be missed. Stated

\footnotetext{
${ }^{127}$ Interview No. 9, November 6, 2015.

${ }^{128}$ Interview No. 15, December 21, 2015.
} 
differently, how judges behave depends on what they care about, and there is no doubt that different judges care about different things (See Baum 2006). Future studies of sentencing behavior and judicial behavior more generally should use more mixed-method and direct observational studies to better understand differences that exist amongst district court judges.

This latest point on judicial variation relates to the third important takeaway from this study: the potentially overrated impact of judicial partisanship on sentencing decisions. Subjects were generally hostile to the notion that partisanship explained district court judges' sentencing behavior. This finding highlights the limitations of more simplistic models of district court sentencing behavior, based largely on partisanship (See e.g. Epstein, et. al., 2013).

This is not to suggest that judges appointed by Democratic Presidents sentence identically to judges appointed by Republican Presidents on average. Past findings suggest that, although the effects are small, Democratic judges are more likely to grant Guideline departures (Epstein, et. al. 2013; Fischman and Schanzenbach 2011). Still, the findings of this study suggest that partisanship and ideology are not always strong predictors of a judges' sentencing preference.

The potential lack of import of district court judges' personal partisanship/ideology on sentencing behavior has major implications for judicial behavior and sentencing policy. First, it might be that consistent with Zorn \& Bowie (2010) and Ashenfelter, et. al. (1999), but inconsistent with Rowland, et. al. (1996) and Sisk and Heise (2012) personal policy preferences are not all that important in explaining district court decisions. If this is the case, dominant theories of appellant judicial behavior, such as the attitudinal model (Segal and Spaeth 2002) would be in need of serious modification when applied to trial judges. On the other hand, another interpretation of limited partisan/ideological influence in sentencing is simply that criminal justice policy is becoming a bipartisan issue that mitigates partisan/ideological 
differences between judges (See Zlotnick 2009). Indeed, as discussed above, many subjects were sympathetic to this view. More global studies of district court behavior across different policy areas could potentially test the relevant weight of these explanations.

The final point worthy of discussion relates to the extent the results improve upon past studies of federal sentencing. Specifically, to what extent do the results shed light on the two "puzzles" identified at the outset of this research: 1) the gradual and continued increase in belowGuideline sentences after 2005; and 2) inter-district variation in sentencing outcomes? The answer to this question demonstrates both the strengths and limitations of the results.

As to the gradual increase in the proportion of below-Guideline sentences, the results both provide support for "habitual" explanations and for the alternative theory of judicial policy evaluation. In other words, it remains an open question whether district court judges are still simply "getting used" to their authority to sentence as they please as opposed to them actually altering their sentencing preferences as they observe the problems associated with long sentences. As discussed previously, results from the interviews suggest that both theories have some merit.

Even if not solely resolving the puzzle, the finding that at least some judges are softening policy preferences in the face of evidence of the incarceration problem is important. This conclusion implies that district judges have some power to rationally change policy, even in the absence of explicit policymaking power. Whether this power for district judges is interpreted as a normatively positive development probably depends on one's view of the ideal role of the judiciary. Yet strictly from an institutional standpoint, evidence of some policy evaluation and adaptation by district court judges is independently intriguing. 
As to Puzzle \#2, the results were less successful in explaining why sentencing differences in districts persist. In general, many subjects agreed that local cultural effects explained district differences. However, in general, it was difficult to detect any patterns of responses or clear differences between subjects in one district vs. subjects in other districts. Part of the difficulty was the small number of subjects within each district, making it difficult to generalize on district differences. Another difficulty was the fact that many subjects had themselves only practiced it their home district, which prohibited them from opining on how their district was (or was not) different.

These limitations of the study should not undermine its contributions. The subject interviews provide strong evidence that some judges in certain situations are sensitive to local contextual matters when making sentencing decisions. This conclusion, while certainly conditional and not entirely satisfying, is nevertheless extremely important. Federal district court judges, even if unelected, remain members of local communities. A subset of district court judges clearly care both about both their local reputations and the consequences of the policies in these local communities. So long as these judges exist, district court behavior is unlikely to be fully explained by either partisan/ideological factors or by top-down legal rules.

\section{References}

Alexander, Michelle. 2012. The New Jim Crow: Mass Incarceration in the Age of Colorblindness. The New Press.

American Bar Association. 2014. "A Current Glance at Women in the Law." Accessible at: http://www.americanbar.org/content/dam/aba/marketing/women/current_glance_statistics_july2014.authch eckdam.pdf

American Bar Association. 2003. "A Current Glance at Women in the Law." Accessible at: http://www.americanbar.org/content/dam/aba/migrated/women/reports/glance2003.authcheckdam.pdf

Ashenfelter, Orley, Theodore Eisenberg, and Stewart J. Schwab. 1995. "Politics and the judiciary: The influence of judicial background on case outcomes." The Journal of Legal Studies 24(2): 257-281.

Atkins, Burton, Lenore Alpert, and Robert Ziller. 1980. "Personality Theory And Judging: A Proposed Theory of Self-Esteem and Judicial Policy-Making." Law \& Policy 2(2):189-220. 
Baum, Lawrence. 2009. Judges and Their Audiences: A Perspective on Judicial Behavior. Princeton University Press.

Baumgartner, Frank R., Jeffrey M. Berry, Marie Hojnacki, Beth L. Leech, and David C. Kimball. 2009. Lobbying And Policy Change: Who Wins, Who Loses, And Why. University of Chicago Press,

Ulmer, Jeffery T. 2005. "The Localized Uses of Federal Sentencing Guidelines in Four U.S. District Courts: Evidence of Processual Order," 28 Symbolic Interaction 255.

Beckmann, Matthew N. and Richard Hall. 2013. "Elite Interviewing in Washington, DC.," in Interview Research in Political Science., ed. Layna Mosley. Cornell University Press.

Blanck, Peter David, Robert Rosenthal, Allen J. Hart, and Frank Bernieri. 1989. "Measure of the Judge: an Empirically-Based Framework for Exploring Trial Judges' Behavior." Iowa L. Rev. 75: 653.

Bleich, Eric and Robert Pekkanen. 2013. "How to Report Interview Data." in Interview Research in Political Science., ed. Layna Mosley. Cornell University Press.

Casillas, Christopher J., Peter K. Enns, and Patrick C. Wohlfarth. 2011. "How Public Opinion Constrains the US Supreme Court." American Journal of Political Science 55(1): 74-88.

Church Jr, Thomas, Alan Carlson, Jo-Lynne Quong Lee, Teresa Tan, Kenneth Chantry, and Larry L. Sipes. 1978. "Justice delayed: The pace of litigation in urban trial courts." State Ct. J. 2: 3-41.

Clear, Todd R., and Natasha A. Frost. 2015. The Punishment Imperative: The Rise And Failure Of Mass Incarceration In America. NYU Press,

Cohen, Jeffrey E. 1999. Presidential Responsiveness and Public Policy-Making: The Public and the Policies that Presidents Choose. University of Michigan Press.

Cook, Beverly B. 1973. “Sentencing Behavior of Federal Judges: Draft Cases, 1972.” Cincinnati Law Review 42:597-633.

Currie, Elliott. 2013. Crime and Punishment in America. Macmillan.

Czopp, Alexander M., and Margo J. Monteith. 2003. "Confronting prejudice (literally): Reactions to confrontations of racial and gender bias." Personality and Social Psychology Bulletin 29(4): 532-544.

Eisenstein, James, and Herbert Jacob. 1977. Felony Justice: An Organizational Analysis of Criminal Courts. Boston: Little Brown.

Enns, Peter. 2014. “The Public's Increasing Punitiveness and Its Influence on Mass Incarceration in the United States" The American Journal of Political Science. 58(4): 857-872.

Enns, Peter and Julianna Koch. 2013. "Public Opinion in the US States 1956 to 2010." State Politics \& Policy Quarterly 13(3): 349-372.

Epstein, Lee, and Jack Knight. 1998. The Choices Justices Make. CQ Press.

Epstein, Lee, William M. Landes, \& Richard A. Posner. 2013. The Behavior of Federal Judges. Cambridge, MA: Harvard University Press.

Federal Judicial Center. 2014. "Biographical Directory of Federal Judges, 1789-Present.” Accessible at: http://www.fjc.gov/history/home.nsf/page/judges.html

Fischman, Joshua B., \& Max M. Schanzenbach. 2012. "Racial Disparities under the Federal Sentencing Guidelines: The Role of Judicial Discretion and Mandatory Minimums," Journal of Empirical Legal Studies 9:729-64. 
Fischman, Joshua B. \& Max Schanzenbach. 2011 "Do Standards of Review Matter? The Case of Federal Criminal Sentencing." Journal of Legal Studies 40:405-437.

George, Alexander L., \& Bennett, Andrew. 2005. Case Studies and Theory Development in the Social Sciences. Cambridge, MA: MIT Press.

Gibson, James L. 1980. "Environmental Constraints on the Behavior of Judges: A Representational Model of Judicial Decision Making. Law \& Society Review 14:343-370.

Gibson, James L. 1978. “Judges' Role Orientations, Attitudes, and Decisions.” American Political Science Review 72:911-924.

Hilbink, Lisa. 2007. Judges Beyond Politics in Democracy and Dictatorship: Lessons From Chile. Cambridge University Press.

Hinkle, Rachael K. 2015 "Legal Constraint in the US Courts of Appeals." The Journal of Politics 77(3):721-735.

Hofer Paul J. 2013. "The Commission Defends an Ailing Hypothesis: Does Judicial Discretion Increase Demographic Disparity?," Federal Sentencing Reporter 25:311-22.

Hofer, Paul J. \& Mark H. Allenbaugh. 2003. "The Reason Behind the Rules: Finding and Using the Philosophy of the Federal Sentencing Guidelines" American Criminal Law Review. 40: 19-29.

Holder, Eric. 2010. "Memorandum from Eric H. Holder, Jr., Attorney General, to All Federal Prosecutors." Accesible at: http://www.justice.gov/oip/holder-memocharging-sentencing.pdf.

Hume, Robert J. 2009. The Impact of Judicial Opinion Language on the Transmission of Federal Circuit Court Precedents. Law \& Society Review,43(1):127-150.

Jacobs, David, and Jason T. Carmichael. 2001. "The politics of punishment across time and space: A pooled timeseries analysis of imprisonment rates." Social Forces 80(1): 61-89.

Johnson, Brian, Jeffery T. Ulmer, and John H. Kramer. 2008. "The Social Context of Guidelines Circumvention: The Case of Fedearl District Courts." Crimonology 46(3):737-783

Jones, Bryan D., and Frank R. Baumgartner. 2005. The Politics Of Attention: How Government Prioritizes Problems. University of Chicago Press.

Kautt, Paula M. 2002. "Location, Location, Location: Interdistrict and Intercircuit Variation in Sentencing Outcomes for Federal Drug-Trafficking Offenses." Justice Quarterly 19(4): 633-671.

Kim, Pauline T. 2009 "How Should We Study District Judge Decision-Making?." Washington University Journal of Law and Policy 29:83

Kingdon. John W. 1981. Congressmen's Voting Decisions. $2^{\text {nd }}$ ed. New York: Harper Row.

Kritzer, Herbert. 2012. "Understanding Trial Courts Means Understanding Lawyers." Newsletter Of The Law \& Courts Section Of The American Political Science Association 22(2):8-14.

Kritzer, Herbert. 1978. "Political Correlates of the Behavior of Federal District Judges: A Best Case Analysis." Journal of Politics 40:25-58.

Kritzer, Herbert M.,and Frances Kahn Zemans. 1993. "Local legal culture and the control of litigation." Law \& Society Rev. 27:535-558 
Levin, Martin A. 1972. "Urban politics and judicial behavior." The Journal of Legal Studies 1(1): 193-221.

Lynch, Mona. 2011. "Mass Incarceration, Legal Change and Locale: Understanding and Remediating American Penal Overindulgence," Criminology and Public Policy 10: 671-98.

Lynch, Mona and Marisa Omori. 2014. "Legal Change and Sentencing Norms in the Wake of Booker: The Impact of Time and Place on Drug Trafficking Cases in Federal Court." Law and Society Review 48 (2):411-445.

Macdonald, Jason A. 2007. "The US Congress and the Institutional Design of Agencies." Legislative Studies Quarterly 32(3): 395-420.

Martin, Kathie. 2013. "Crafting Interviews to Capture Cause and Effect." in Interview Research in Political Science., ed. Layna Mosley. Cornell University Press.

Miceli, Thomas J., and Metin M. Coşgel. 1994. "Reputation and judicial decision-making." Journal of Economic Behavior \& Organization 23(1): 31-51.

Mishler, William, and Reginald S. Sheehan. 1996. "Public Opinion, The Attitudinal Model, And Supreme Court Decision Making: A Micro-Analytic Perspective." The Journal of Politics 58(1):169-200.

Morriss, Andrew P., Michael Heise, and Gregory C. Sisk. 2005. "Signaling and precedent in federal district court opinions." Supreme Court Economic Review 13: 63-97.

Mosley, Layna. 2013. “ “Just talk to people'? Interviews in Contemporary Political Science.” in Interview Research in Political Science., ed. Layna Mosley. Cornell University Press.

Mustard, David B. 2001. "Racial, Ethnic, And Gender Disparities In Sentencing: Evidence From The Us Federal Courts." Journal of Law and Economics 44(1): 285-314.

Nardulli, Peter F. 1986. "Insider Justice: Defense Attorneys and the Handling of Felony Cases." J. Crim. L. \& Criminology 77: 379-417.

Nicholson-Crotty, Sean, David A.M. Peterson, and Mark D. Ramirez. 2009. "Dynamic Representation(s): Federal Criminal Justice Policy and an Alternative Dimension of Public Mood.” Political Behavior 31(4):629-655.

Page, Benjamin I., Robert Y. Shapiro, and Glenn R. Dempsey. 1987. "What moves public opinion?." American Political Science Review 81(1): 23-43.

Pattillo, Mary, Bruce Western, and David Weiman, eds. 2004. Imprisoning America: The Social Effects of Mass Incarceration: The Social Effects of Mass Incarceration. Russell Sage Foundation.

Posner, Richard A. 2009. Law, Pragmatism, And Democracy. Harvard University Press.

Posner, Richard A. 2010. How Judges Think. Harvard University Press.

Przeworski, Adam and Henry Teune. 1970. The Logic of Comparative Social Inquiry. New York: John Wiley and Sons.

Rehavi, M. Marit, \& Sonia Starr. 2012. "Racial Disparity in Federal Criminal Charging and Its Sentencing Consequences," U of Michigan Law \& Econ, Empirical Legal Studies Center Paper (12-002)

Rosenberg, Gerald N. 1991. The Hollow Hope: Can Courts Bring About Social Change?. University of Chicago Press.

Rowland, C.K. \& Robert A. Carp. 1996. Politics and Judgment in Federal District Courts. Lawrence, KS: University of Kansas Press. 
Schanzenbach, Max M. and Emerson H. Tiller. 2007. "Strategic Judging Under the US Sentencing Guidelines: Positive Political Theory and Evidence." Journal of Law, Economics, and Organization 23(1): 24-56.

Scheb, John M., Terry Bowen, and Gary Anderson. 1991. "Ideology, role orientations, and behavior in the state courts of last resort." American Politics Quarterly 19(3): 324-335.

Segal, Jefferey A. and Harold J. Spaeth. 2002. The Supreme Court and the Attitudinal Model Revisted. New York: Cambridge University Press.

Simon, Dan. 2004. "A third view of the black box: Cognitive coherence in legal decision making." The University of Chicago Law Review: 511-586.

Sisk, Gregory C., and Michael Heise. 2012. "'Ideology' All the way down"? An Empirical Study of Establishment Clause Decisions in the Federal Courts." Michigan Law Review 110(7): 1201-1263.

Sisk, Gregory S., Michael Heise, and Andrew P. Morriss. 1998. "Charting the Influences on the Judicial Mind: An Empirical Study of Judicial Behavior.” New York University Law Review 73: 1377-1500.

Songer, Donald R. 1979. "Concern for policy outputs as a cue for Supreme Court decisions on certiorari." The journal of Politics 41(4):1185-1194.

Spaeth, Harold J., and Jeffrey A. Segal. 2001. Majority rule or minority will: Adherence to precedent on the US Supreme Court. Cambridge University Press.

Stidham, Ronald, Robert A. Carp, and Donald R. Songer. 1996. "Voting Behavior of President Clinton's Judicial Appointees, The." Judicature 80:16.

Tansey, Oisin. 2007. "Process Tracing and Elite Interviewing: A Case for Non-Probability Sampling." PS: Political Science \& Politics, 40(04):765-772.

Tiller, Emerson H. \& Frank B. Cross. 1999. “A Modest Proposal for Improving American Justice” Columbia Law Review 99:215-236.

Ulmer, Jeffery T. 2005. "The Localized Uses of Federal Sentencing Guidelines in Four U.S. District Courts: Evidence of Processual Order," Symbolic Interaction 28: 255.

Ulmer, Jeffery T. \& Mindy S. Bradley. 2006. "Variation in Trial Penalties Among Serious Violent Offenses." Criminology 44:631-670.

United States Sentencing Commission. 2012. Report on the Continuing Impact of United States v. Booker on Federal Sentencing. Washington, DC: US Sentencing Commission.

United States Sentencing Commission. 2011. Report to the Congress: Mandatory Minimum Penalties in the Federal Criminal Justice System. Washington, DC: US Sentencing Commission.

United States Sentencing Commission. 2004. Fifteen Years of Guidelines Sentencing: An Assessment of How Well the Federal Criminal Justice System is Achieving the Goals of Sentencing Reform. Washington, DC: US Sentencing Commission.

United States Sentencing Commission. 1995-2014. Sourcebook of Federal Sentencing Statistics. Retrieved from: http://www.ussc.gov/Research_and_Statistics/Annual_Reports_and_Sourcebooks/Archives.cfm

Western, Bruce. 2002. "The Impact of Incarceration on Wage Mobility and Inequality." American Sociological Review: 67(4):526-546. 
Wu, Jawjeong \& Cassia Spohn. 2010. "Interdistrict Disparity in Sentencing in Three U.S. District Courts." Crime and Delinquency 56: 290-322.

Zegart, Amy B. 2013. “The Domestic Politics of Irrational Intelligence Oversight.” Political Science Quarterly, 126(1), 1-25.

Zlotnick, David M. 2008. "Future of Federal Sentencing Policy: Learning Lessons from Republican Judicial Appointees in the Guidelines Era." The University of Colorado Law Review 79:1-76.

Zorn, Christopher, and Jennifer Barnes Bowie. 2010. "Ideological Influences on Decision Making in the Federal Judicial Hierarchy: An Empirical Assessment.” Journal of Politics 72:1212-21. 


\section{Table 1: District Traits}

\begin{tabular}{|l|l|l|}
\hline \multicolumn{1}{|c|}{ District Trait } & \multicolumn{1}{|c|}{$\begin{array}{c}\text { Traits of at Least one } \\
\text { Selected District }\end{array}$} & $\begin{array}{l}\text { Traits not Represented by } \\
\text { Selected Districts }\end{array}$ \\
\hline Region & $\begin{array}{l}\text {-Mid-Atlantic } \\
\text {-Southern } \\
\text {-Midwestern }\end{array}$ & $\begin{array}{l}\text { - Northeastern } \\
\text { - Western }\end{array}$ \\
\hline Population & $\begin{array}{l}\text {-large }>5 \text { million residents) } \\
\text {-medium }>2 \text { million but }<5 \text { million } \\
\text { residents) }\end{array}$ & -small (<2 million residents) \\
\hline Urban/Rural & $\begin{array}{l}\text {-majority urban } \\
\text {-majority rural }\end{array}$ & $\mathrm{n} / \mathrm{a}$ \\
\hline $\begin{array}{l}\text { Partisan Composition of } \\
\text { Judges Last Decade }\end{array}$ & $\begin{array}{l}\text {-majority Republican } \\
\text {-majority Democrat }\end{array}$ & $\mathrm{n} / \mathrm{a}$ \\
\hline $\begin{array}{l}\text { Racial/Ethnic } \\
\text { Demographics of Districts }\end{array}$ & $\begin{array}{l}\text {-10-20\% African American } \\
\text { population } \\
\text {-greater than 20\% African American } \\
\text { population } \\
\text {-10-20\% Hispanic population } \\
\text {-less than 10\% Hispanic population }\end{array}$ & $\begin{array}{l}\text {-gmerican population } \\
\text { population } 20 \% \text { Hispanic }\end{array}$ \\
\hline $\begin{array}{l}\text { Political Ideology of } \\
\text { Citizens in Districts }\end{array}$ & $\begin{array}{l}\text {-conservative } \\
\text {-liberal }\end{array}$ & $\mathrm{n} / \mathrm{a}$ \\
\hline
\end{tabular}


Table 2: Aggregate Subject Characteristics

\begin{tabular}{|l|l|}
\hline Experience & $\begin{array}{l}\text { Median Subject Experience: } 24 \text { years } \\
\text { Minimum Subject Experience: 13 years } \\
\text { Maximum Subject Experience: 43 years } \\
\text { Total Years Experience: } 460 \text { years }\end{array}$ \\
\hline Profession & $\begin{array}{l}4 \text { former federal district court judges; } \\
2 \text { federal district court judges; } \\
3 \text { federal public defenders; } \\
4 \text { private practice criminal defense attorneys; } \\
2 \text { assistant U.S. Attorneys; } \\
4 \text { "hybrid" former U.S. Attorneys current } \\
\text { private practice criminal defense attorneys. }\end{array}$ \\
$\begin{array}{l}16 \text { Males } \\
3 \text { Females }\end{array}$ \\
\hline Gender & $\begin{array}{l}17 \text { White } \\
2 \text { African Americans } \\
0 \text { Hispanics }\end{array}$ \\
\hline Race/Ethnicity & \\
\hline
\end{tabular}


Table 3: Percentages of Subjects Agreeing that Contextual Variables Impact Federal District Court Judges Sentencing Decisions

\begin{tabular}{|l|c|c|c|}
\hline $\begin{array}{c}\text { Contextual Source of } \\
\text { Influence }\end{array}$ & $\begin{array}{c}\text { Unqualified } \\
\text { Agreement }\end{array}$ & $\begin{array}{c}\text { Qualified } \\
\text { Agreement }\end{array}$ & Total Agreement \\
\hline $\begin{array}{l}\text { Local Legal Community } \\
\text { Opinion }\end{array}$ & $37 \%$ & $26 \%$ & $63 \%$ \\
\hline Local Public Opinion129 & $33 \%$ & $11 \%$ & $44 \%$ \\
\hline Incarceration Rates 130 & $12 \%$ & $41 \%$ & $53 \%$ \\
\hline Crime Rates 131 & $21 \%$ & $32 \%$ & $53 \%$ \\
\hline
\end{tabular}

\footnotetext{
${ }^{129}$ Due to time constraints, one interview subject was unable to answer questions regarding local public opinion.

${ }^{130}$ Due to time constraints, two interview subjects were unable to answer questions regarding the incarceration rates.

${ }^{131}$ One interview subject insisted that while the actual crime rates were probably not important, judges' "perceptions of the crime rate" were influential. This subject was coded as "Qualified Agreement" as it is consistent with the theory that judges are sensitive to local criminal issues, even if that concern is based on perception, rather than reality.
} 


\section{Appendix A: Question Bank}

Thank you for taking the time to speak with me today and answer some questions. The interview should take 45 minutes to 1 Hour. Please remember that your participation in this research is entirely voluntary and you can cease your participation at any time. Please also feel free to add any thoughts and/or impressions you may have.

First, I have some general questions about you and your experience in [Name of Federal District Court]

1) Please state your name, job title, business address, and business telephone number.

2) What is your experience in criminal law in [Name of Federal District Court]?

3) What job titles or positions have you held that give you this experience, and what years were you in each position?

4) How familiar are you with general federal sentencing practice in [Name of Federal District Court]?

5) How familiar are you with the application of the United States Sentencing Guidelines in [Name of Federal District Court]?

6) Which judges, if any, in [Name of Federal District Court] do you have experience appearing in front of, and/or working with?

Now I have some general questions regarding your opinion of sentencing practice in [Name of Federal District Court]

7) What is your overall opinion of sentencing practice in [Name of Federal District Court]?

8) What is your overall opinion of the US Sentencing Guidelines [Name of Federal District Court]?

9) What would you say are the strengths of the US Sentencing Guidelines and their application? 
10) What would you are the weaknesses of the US Sentencing Guidelines and their application?

11) In general, would you say criminals are treated fairly or unfairly under the US Sentencing Guidelines in [Name of Federal District Court]? Please explain.

12) In general, would you say that federal district court judges have too much discretion, not enough discretion, or about the right amount of discretion in making sentencing decisions?

13) How familiar are you with the procedure of "departures" from the US Sentencing Guidelines?

14) Based on your experience in [Name of Federal District Court], do you generally think there should be more departures form the Guidelines, less departures form the Guidelines, or about right?

15) In your opinion, why do you think a given judge in [Name of Federal District Court] may depart from the Guidelines in the case of some offenders, but not other offenders?

16) What are some reasons you believe that some judges in [Name of Federal District Court] might grant departures from the Guidelines more often than other judges?

Now I'm going to list some possible explanations for why a judge may depart from the Guidelines. For each, please tell me whether or not you believe the potential explanations to be valid, and if so to what extent.

17) Generally speaking, do you believe the race of the offender affects departure decisions? If so, in what way?

18) Generally speaking, do you believe the gender of the offender affects departure decisions? If so, in what way?

19) Generally speaking, do you believe the race of the sentencing judge affects departure decisions? If so, in what way?

20) Generally speaking, do you believe the gender of the sentencing judge affects departure decisions? If so, in what way? 
21) Generally speaking, do you believe the opinions or preferences of the local legal community impact district court judges in their departure decisions? If so, in what way?

22) Generally speaking, do you believe the opinions or preferences of the general public impact district court judges in their departure decisions? If so, in what way?

23) Generally speaking, do you believe the type of crime the offender committed (drug trafficking, firearms, etc.) affects departure decisions? If so, in what way?

24) Generally speaking, do you believe that whether the conviction is reached by plea agreement or jury conviction affects departure decisions? If so, in what way?

25) Generally speaking, do you believe the U.S. Attorney's Office prevalence of charging crimes that carry mandatory minimum sentences affects departure decisions? If so in what ways?

26) Generally speaking, do you believe the U.S. Attorney's Office prevalence of using "substantial assistance" departures, or other government-sponsored departures affects departure decisions? If so in what ways?

27) Generally speaking, do you believe the political party of the sentencing judge (based upon the political party of the appointing US President) affects departure decisions? If so, in what way?

28) Generally speaking, do you believe the personal ideology of the sentencing judge (based upon the political party of the appointing US President) affects departure decisions? If so, in what way?

29) Generally speaking, do you believe the political ideology of the local area affect departure decisions? If so, in what way?

30) Generally speaking, do you believe the prevalence of crime, or the crime rate in the local area affect departure decisions? If so, in what way?

31) Generally speaking, do you believe the incarceration rate in the local area affect departure decisions? If so, in what way?

32) Is there anything I haven't mentioned that you believe impacts departure decisions? 
Now I have some specific questions regarding your opinion of sentencing practice in [Name of Federal District Court]

33) Do you believe [Name of Federal District Court]? is more punitive or less punitive than average?

34) Why would you suspect this is the case?

Now I'm going to ask you some questions regarding how you think sentencing practice has changed in [Name of Federal District Court] sine your experience began.

35) From a general perspective, how has life in the areas of jurisdiction of the [Name of Federal District Court] changed since your experience began?

36) Do you think these general changes have affected sentencing practice in [Name of Federal District Court]? If so, in what way?

37) In your opinion, how, if at all, did the 2005 US Supreme Court case of US $v$. Booker alter sentencing practice in your district?

38) Do you agree with the portion of US v. Booker that holds that the US Sentencing Guidelines cannot be mandatory on sentencing judges?

Finally, I'm going to conclude by asking you some general questions?

39) Is there anything you would like to add that we have not covered that you think is particularly relevant to this subject-matter?

40) Is there any other person with experience in [Name of Federal District Court] that you believe could answer some of these questions or otherwise be beneficial to this research effort?

Thank you for your time. I truly appreciate your participation in this research. 


\section{Chapter 5: Conclusion}


The major argument I advance in this dissertation is that the criminal sentencing decisions of federal district court judges are dynamic and complex. These decisions cannot be fully explained by district judges' individual partisan preferences. Nor can different eras of judicial discretion (e.g. pre-Booker or post-Booker) account for certain peculiarities in federal sentencing policy, such as differences in districts or the continued increase in below-Guideline sentences post-Booker.

Instead, I theorized in Chapter 1 that district judges' decisions are likely impacted by certain contextual conditions that exist in their community. In particular, I argued the punitive preferences of both the local legal community and the general public would likely impact judges' sentencing decisions. In addition, I argued that pertinent objective conditions, such as crime rates and incarceration rates, had the potential to alter district judges' sentencing preferences and thus influence outcomes.

In this Conclusion, I assess the degree to which the findings of each empirical chapter support this argument. First, I discuss the results for each of the four specific variables as well as contextual determinants generally. Next, I relate the findings back to the societal problem of incarceration and discuss some important implications for understanding the role of the judiciary in addressing policy problems. Finally, I discuss potential avenues for future research, both in federal sentencing policy and in other policy areas.

\section{Do Contextual Factors Matter?}

The theoretical basis for why district judges might be sensitive to certain conditions in their communities when making sentencing decisions is discussed at length in Chapter 1 and throughout this dissertation. In brief, I argue that federal district court judges are, to some extent, products of their environment. They live and work within particular geographic districts, and 
like all individuals, district judges are to some degree shaped by these places. While district judges certainly have personal views and personal preferences that impact their decisions, these personal views cannot be divorced from "the sociological impact of the community" (Rowland and Carp 1996, 74).

I argue this "sociological impact" of the community is extremely important when studying district judges' criminal sentencing decisions. While district judges' sentences are primarily guided by the circumstances of individual offenders, the evidence in the aggregate data clearly shows that similarly situated offenders are sentenced differently both across the country and over time (USSC 1995-2014; Lynch and Omori 2014; Tiede 2009). Contextual influences largely explain why we see fewer district judges grant below-Guideline sentences in Southern Georgia than in Western Washington (USSC 1995-2014). They also partially illustrate why we observe the continued increase in below-Guideline sentences since they were first implemented in 1987.

In operationalizing my theory of contextual influence, I attempt to move beyond abstract and general concepts of "culture" or "sociological impact" and empirically test specific variables. In particular, using a variety of different models and methods throughout the dissertation, I tested whether: a) public opinion, b) legal community opinion, c) incarceration rates, and d) crime rates affect the likelihood that district judges will issue below-Guideline sentences. A summary of the results for each potential determinant is provided below.

\section{Public Opinion}

The theory that public preferences impact unelected district judges' decisions is premised on the idea that many judges' are concerned about their reputation, despite being unelected. This concern about reputation may be instrumental. District judges who seek to be promoted to 
higher courts must be approved by elected policymakers ${ }^{132}$ accountable to the public. Thus, it would make little sense for these ambitious judges to engender a poor reputation with the public. However, many judges might consider a strong reputation with the public as a goal in and of itself (Baum 2006; Miceli and Cosgell 1994). District judges are almost always long-time residents of their particular district (Rowland and Carp 1996). It would be somewhat curious if they were completely unconcerned with their public standing in a place they lived and worked for a good part of their lives.

This connection between public opinion and district judge criminal sentencing was studied fairly extensively in past decades (Silver and Shapiro 1984; Kritzer 1978; Cook 1977, 1971). However, more recent federal sentencing studies have not assessed the degree to which district judges' post-Guideline sentences are consistent with the "representational model" of judicial behavior. The results from this dissertation provide some conditional evidence of a relationship between public opinion and district judges' criminal sentencing behavior.

The findings of the panel models in Chapter 3 suggest that judges from districts with relatively liberal populaces are more likely to issue below-Guideline sentences than judges from districts with relatively conservative populaces. The findings held both in random and fixedeffect models $^{133}$, suggesting that, even within districts, changes in the ideology of the local population over time were reflected in the sentences issued by district judges. It is an open question whether this observed relationship evidences direct public influence on judges or whether it simply indicates that, as members of the public, judges' preferences move in-step with public opinion (See Casillas, et. al. 2011; Segal and Spaeth 2002; Mishler and Sheehan 1996).

\footnotetext{
${ }^{132}$ U.S. Senators from district judges' home state are particularly important elected figures whom district judges likely need the approval of in order to achieve promotion (Morriss, et. al. 2005).

${ }^{133}$ Although the magnitude of the effects was smaller in fixed-effect models.
} 
Nonetheless, the result is broadly supportive of the "representational model" of judicial behavior, holding that judges' decisions will reflect the preferences of the public (Cook 1977).

In addition to the quantitative results, results from the phone interviews conducted in Chapter 4 provided conditional support for representational behavior by district judges. A significant subset of both attorneys and former district judges stated that judges were sensitive to public concerns about crime and punishment. Many of these subjects also noted that public opinion was more likely to play a role in sentencing outcomes in cases with high levels of media attention. This emphasis on media attention is consistent with a "reputational" theory of district judge decision making. If unelected federal district court judges derive utility from having a good reputation amongst the public (See Miceli and Cosgel 1994; Posner 1993), it makes a great deal of sense that they would be most likely to be influenced by public sentiment in criminal cases when they knew the public was paying attention to the outcome (i.e. high-publicity cases).

Other dissertation results were less supportive of the connection between public preferences and sentencing outcomes. For instance, the national-level analysis conducted in Chapter 2 failed to establish a relationship between the country's general punitive preferences and district judges' sentencing behavior. One potential interpretation of the seemingly inconsistent results regarding pubic influence is that district judges are responsive to the preferences of the public within their own geographic jurisdiction, but not to the general public throughout the country. This interpretation is consistent with conceptions of district judges as representatives of local areas, rather than as agents of a national legal system (Ulmer 2005; Rowland and Carp 1996; Peltason 1971; Vines 1964). Moreover, this interpretation is generally supportive of the above-discussed "reputational" theory of why judges might respond to public preferences. Since few district judges are known by the public outside their district (Goulden 
1974), it makes a good deal of sense that any public influence on district judges' sentencing decisions would be local rather than national.

\section{Legal Community Opinion}

The effect that the preferences of the local legal community have on district judges' criminal sentencing was also examined in this dissertation, albeit only in Chapter 4. The logic underlying local legal community influence is also based on district judges' desire to foster a strong reputation. District judges often have a close working relationship with the attorneys who

practice in their courts (Nardulli, et. al. 1988). Like all individuals, judges desire the respect and esteem of the people with whom they work (Schauer 2000). Given the large proportion of attorneys who view the Guidelines as overly punitive (Hofer and Allenbaugh 2003), it is reasonable to query whether district judges would be influenced by attorney sentiment in their sentencing decisions in order to foster a better reputation.

The results from Chapter 4 lend qualified support to the argument that some district judges are influenced by local legal community views regarding criminal sentencing. Consistent with the findings of Ulmer (2005) and Kautt (2002), several subjects interviewed in Chapter 4 cited local legal community practices as a likely cause of different Guideline departure rates between districts. In addition, one subject noted that district judges' attendance at out-of-court functions (e.g. bar lunches) that involved sentencing matters ultimately ended up affecting district judges' sentencing decisions. Finally, other subjects stated that district judges' individual reputations in the legal community were tied to whether judges were relatively punitive in their sentencing. Thus, there is some qualitative support for the argument that judges' sentencing decisions are impacted by local legal communities. 
Still, all the evidence did not point in this direction. Several subjects questioned whether district judges were influenced by local legal community views. Some of these subjects suggested that judges didn't really care about their reputations among attorneys when making decisions. Other subjects suggested that, while district judges care about their reputation in the legal community, they don't let this concern affect their substantive decision-making.

The mixed results from Chapter 4 suggest that while some district judges can be impacted by the policy preferences of legal communities, other judges are disinclined to pay heed to this group. To more precisely understand how many district judges are influenced by local legal communities and to what degree, there is a need for an expansion of the interview-based research design in Chapter 4 to include more subjects. In addition, there is a need for better quantitative measures of local legal community preferences. This could potentially be achieved in future research by sending questionnaire/surveys to attorneys' with sentencing experience in various federal districts.

\section{Incarceration Rates}

In addition to testing whether district judges' sentences are influenced by the opinions of certain constituencies, this research also probed whether certain objective conditions could impact district judges' sentences. Social scientists have previously analyzed whether certain policymakers' positions could be impacted by changing facts (Jones \& Baumgartner 2005; Cohen 1999). Yet there is little to no research on whether objective facts could also influence judges" policy preferences. Instead, "policy preferences" in the judicial behavior literature is generally treated as conceptually identical to "ideology" (Segal and Spaeth 2002; Epstein \& Knight 1998). Yet ideology is not static, and there is recent evidence that even conservatives have become increasingly hostile to the notion of long sentences for federal criminal offenders 
(Act, et. al. 2015). Accordingly, it is very plausible that changing objective facts related to crime and punishment are a partial cause of district judges' reduced adherence to Guideline sentences in recent years.

The federal incarceration rate is one such objective factor that potentially impacts district judges' sentencing decisions. This rate has exploded since the Guidelines were adopted (U.S. DOJ 2015). Somewhat ironically, however, the explosion largely coincided with a marked increase in the proportion of federal offenders' receiving below-Guideline sentences (USSC 1995-2014). ${ }^{134}$ I argue that the former trend partially caused the latter. As many district judges observed the damaging societal effects of mass incarceration, they adjusted their sentencing preferences in a less punitive direction.

Results from the dissertation suggest many district judges have become attentive to the incarceration problem. The time series results of Chapter 2 evidenced a relationship between higher federal incarceration rates and a higher proportion of downward departures. The relationship was observed in models of both total downward departures, and models of departures excluding substantial assistance cases. ${ }^{135}$

Due to the lack of regional variability in the federal incarceration measure, the variable was not tested in the panel designs of Chapter 3. However, the qualitative results in Chapter 4 provided further evidence that many district judges have altered their sentencing behavior in the face of climbing incarceration. Several subjects, including some current and former district

\footnotetext{
${ }^{134}$ This apparent irony is largely explained by increases in the criminal case-loads for federal courts, the growth in cases with mandatory minimum sentences, and more aggressive law enforcement practices by the federal government (USSC 2012). There is also a "lag-time" effect as shorter sentences in a given year will take some time to be reflected in overall incarceration rate statistics. Still, it appears the increase in below-Guideline sentences is finally having some effect on the objective data, as the federal incarceration rate began declining in 2012 (U.S. DOJ 2015).

${ }^{135}$ Recall that in these models, a certain subset of government sponsored below-Guideline sentences were excluded.
} 
judges, cited anecdotes of judges justifying below-Guideline sentences by citing the problem of over-incarceration.

As with other determinants studied, the degree to which the incarceration rate is influential is not perfectly clear. Objective incarceration statistics are doubtless intertwined with public and elite evaluations of the incarceration problem, which could also impact judges. Furthermore, as set forth in more detail in Chapter 4, district judges' sensitivity to the incarceration problem may be related to their personal political ideology or to their individual conceptual framework for judges' policymaking roles. Still, the findings regarding the impact of incarceration levels on district judges' sentencing preferences is perhaps one of the more important and timely of the dissertation. It suggests many district judges play an active role in addressing policy problems, even when legal standards remain static.

\section{Crime Rates}

Finally, the dissertation sought to examine any connection between crime rates and district judges' punitive sentencing habits. There are several reasons district judges would likely be aware of crime rates. First, they are residents of the community and may have direct experience with crime. Second, judges are well-educated and ambitious individuals who are very likely closely follow local media reports about crime. Finally, and perhaps most importantly, they are professionally exposed to the problem of crime through their role as judges in federal criminal cases.

Assuming judicial awareness of crime levels, the basis for why these levels would impact district judges' sentencing preferences bears similarities to the aforementioned argument for the effect of incarceration rates on judicial sentencing behavior. Essentially, I argue that judges are not solely driven by ideological or reputational concerns but are also individuals who seek to 
attain the "best" consequences with their decisions (Posner 2009). Since both punishment and general deterrence are stated goals of federal sentencing ${ }^{136}$, it's likely that district judges' conceptions of "appropriate sentences" are shaped by their evaluation of the crime problem in their community. Thus, the larger this problem (the higher the crime rate), the more likely judges will seek to punish criminals and deter future criminals by issuing more punitive sentences (See Ulmer and Bradley 2006; Gibson 1980).

Evidence from the dissertation regarding the crime rate's effect on district judges was mixed. The national-level model in Chapter 2 failed to show any significant relationship between crime rates and punitive sentences. On the other hand, the panel design of Chapter 3 provided fairly strong evidence that district judges in higher crime areas issued more punitive sentences. Evidence from interviews conducted in Chapter 4 was ambiguous. Several subjects agreed that district judges in high-crime areas are more likely to embrace deterrence. Thus they would be more prone to issue longer sentences to offenders in order to "send a message" to future criminals. However, other subjects suggested that judges were not concerned with the problem of local crime when sentencing individual offenders and were content to leave this issue up to law enforcement.

Still other subjects suggested high crime rates might have the opposite effect and actually increase the likelihood of below-Guideline sentences. These subjects surmised that judges who reside in lower-crime rural areas would be less familiar with serious crime, and thus more likely to issue harsher sentences. However the models presented in Chapter 3, which control for type and seriousness of crime in each district, did not support this alternative theory presented by subjects. In sum, further testing is clearly needed to determine whether or not crime rates truly impact district judges' sentencing decisions, and if so, in what direction and to what degree.

${ }^{136}$ See 18 U.S.C.\$3553 


\section{The Important Role of Contextual Influences}

Overall, what is to be made of the admittedly mixed results regarding contextual influence on district judges? Probably the most reasonable interpretation of the findings as a whole is that while no one contextual factor is of paramount importance to district judges, many judges will take into account certain conditions in the community when make sentencing decisions. Thus, contextual variables should no longer be excluded from studies of district judges' sentencing behavior (See Epstein, et. al. 2013; Fischman and Schanzenbach 2011). The importance of these contextual determinants in general is demonstrated by several findings of the dissertation.

First, the explanatory power of quantitative models of district judges' departure decisions presented in both Chapters 2 and 3 were improved once the exogenous environmental variables were included. The relative strength of quantitative models that include these variables implies that more simplistic models of district judges' sentencing are likely to underestimate important community-based influences. In other words, past research studies of federal sentencing trends that only assessed the impact of judicial partisanship, policy change, or prosecutorial practices are capable of providing only partial explanations for sentencing outcomes (See Lynch and Omori 2014; Epstein, et. al. 2013; Fischman and Schanzenbach 2011).

In addition, results from Chapter 4 of the dissertation, while mixed as to each individual factor, demonstrated fairly strong support for contextual influence in general. Very few subjects ( 2 of 19) believed that all four of the environmental influences studied were unimportant in shaping district judges' sentencing decisions. This finding further bolsters the claim that the contextual conditions existing in the community are an important aspect of understanding why district judges' derive their sentencing decisions. 
Admittedly, the impact of contextual variables on district judges sentencing also appears to be highly conditional. There is variability among district judges as to the degree to which community influences are important. Some district judges are undoubtedly very concerned with the local public or the local legal communities' views on sentencing, while other district judges pay less heed to these groups (Schauer 2000). Similarly, some judges clearly care about broader social conditions, such as crime rates or incarceration rates, when making sentencing decisions, while other judges will be unaffected. This finding confirms that judicial sentencing decisions are inextricably a reflection of the frame of reference of a given judge.

As discussed in more detail below, the conditional nature of contextual influence suggests future studies of district judges should seek to determine which judges are likely to internalize environmental conditions and in what type of cases those conditions are likely to be most important. Still, the findings in this dissertation strongly imply that it would be a mistake for scholars to limit future sentencing studies to judicial partisanship or legal rules and ignore the differing contextual backgrounds in which sentencing decisions are made. In many instances, these community-level factors will play an important role in determining the ultimate outcome for federal offenders.

\section{District Judges' Roles and the Incarceration Problem}

Moving beyond the importance of various contextual variables, the results of the dissertation also advance understandings of district judges' role within a punitive federal sentencing framework. There is no doubt the federal sentencing framework that was adopted in 1984 and implemented in 1987 created a regime that drastically increased the length of prison sentences for federal offenders. This rise in federal incarceration has been disproportionately felt by African-American and Hispanic communities, and now over 1 in 300 males of color in the 
United States are currently serving time in federal prison (DOJ 2015). Given the problem, an important question to ask relates to district judges' role in this system. Namely, are district judges contributing to the systemic problem of over-incarceration? Or, alternatively, do district judges act as bulwark against even more punitive outcomes?

From the perspective of critics of punitive sentencing, this dissertation unequivocally finds that district judges are part of the solution rather than part of the problem. First, the raw data demonstrates that more than half of offenders in FY 2014 received below-Guideline sentences, and offenders are now nearly 25 times more likely to receive below-Guideline sentences than above-Guideline sentences (USSC 1995-2014). These facts demonstrate that district judges clearly question the baseline appropriateness of Guideline-level sentences in a large segment of cases.

Secondly, evidence from Chapters 2 and 4 suggest the increase in below-Guideline sentences was not merely the byproduct of any increase in the proportion of Democratic judges that sat on the District Court. Instead, the increase in below-Guideline sentences is at least partially explained by changes to sitting district judges' own preferences for optimal sentences. Specifically, quantitative evidence from Chapter 2 and qualitative evidence from Chapter 4 demonstrate district judges' gradual acknowledgement that long sentences were not only an ineffective criminal justice policy, but were also damaging to society.

Finally, some findings from the dissertation suggest that any connection between public punitive preferences and policymaker behavior may soon result in a more dramatic revolt against Guideline-level sentences. Results from Chapters 3 and 4 suggest that district judges' punitive behavior may be related to the local public's preferences. ${ }^{137}$ Unlike the previously discussed

\footnotetext{
${ }^{137}$ Although recall that in Chapter 3, general ideology was used as a proxy variable for public punitive preferences. To the extent this relationship between conservative ideology and punitive preferences is weakening in recent years
} 
results, this finding is not necessarily indicative of district judges' resistance to an overly

punitive sentencing regime. Indeed, recent scholars of criminal justice policy have attributed the decades-long policy of long prison sentences to the effect that a fearful public has on policymakers (Enns 2014; Nicholson-Crotty, et. al. 2009).

Yet, the public's attitudes are changing. For instance, a 2014 Pew Poll finds that $63 \%$ of the public now oppose mandatory minimum sentences for non-violent drug offenders, up from 47\% in 2001 (Pew 2014). More broadly, Enns' (2014) measure of general public punitiveness peaked in the early 1990s. Thus, while the connection between public preferences and policymaker behavior has generally been regarded as being partially responsible for the rise in incarceration in this country, recent trends suggest that any connection may produce less punitive outcomes in the future. ${ }^{138}$

\section{Future Areas of Research}

Finally, the results of this dissertation provide several opportunities of further study of the contextual influence on district judges. One such opportunity is to expand the interview project conducted in Chapter 4 to include more interview subjects from more districts. This would serve several purposes. First, it would increase the sample of subjects and potentially allow for stronger causal statements regarding the effect of contextual variables on district judges' sentencing decisions. Relatedly, a larger and more diverse array of subjects would improve the generalizability of the results. Two clear limitations of the research conducted in Chapter 4 were the underrepresentation of female subjects and the total lack of perspectives from attorneys

(See e.g. Act, et. al. 2015), the ability of the findings of Chapter 3 to forecast a future link between public punitive preferences and district judges' sentences is also weakened.

${ }^{138}$ Although as discussed in Chapter 3, the connection between public preferences and judicial sentencing also has the potential to exacerbate racial disparities in sentencing. This is especially likely if Southern populaces are less likely to have changed their views on punitive sentencing than other Americans. 
and judges in Western or small, rural districts. Third, an expanded project could more appropriately analyze any differences in opinion among sub-groups (e.g. defense attorneys vs. U.S. Attorneys) as to what factors are most important in explaining sentencing outcomes.

Another opportunity for future studies of contextual influence on district judges is to use direct observation. Both Kritzer (1998) and Blank, et. al. (1989) argue that observation of both lawyers and judges is a particularly useful method for studying trial courts. These scholars suggest that since many of the important decisions of trial courts are made in the courtroom, social scientists should observe how both attorneys and trial judges behave during court proceedings. This type of observational research could be used to evaluate how district judges respond to attorneys' arguments that judges should consider broader community concerns when sentencing individual offenders. Results from Chapter 4 suggest that many attorneys do in fact appeal to societal issues such as the crime rates or incarceration rates when making arguments to district judges regarding appropriate sentences. Direct observation of sentencing hearings could evaluate how often these appeals made by attorneys and how they are received by district judges during hearings. These observations could then be supplemented with analyses of decisions to assess whether district judges are more or less likely to ultimately rule in favor of the attorneys making these socially-framed arguments.

Another opportunity for future research is related to a key finding of this dissertation: variability among district judges. As discussed at length by Baum (2006), failure to account for differences in judges' hierarchy of goals is one of the weaknesses of the dominant models of judicial behavior. Some judges' decisions will be guided largely by their ideology and personal preferences. Other judges might primarily be concerned with their reputations among certain 
groups and thus decide cases with the goal of preserving this reputation. Still other judges might be concerned with making the best public policy in light of the available information.

But empirically, how large is each of these groups of judges? In addition, is there anything systematic about each type of judge that would allow us to better understand why they are different? From a research perspective, perhaps the best way to answer these questions with respect to district judges is to conduct intensive studies of individual districts. This type of design would allow researchers to determine how different judges potentially respond differently to the same environments. It would also make a strong supplement to the expanded interview project discussed above, which would focus on the differences of judges operating in different contexts.

Finally, another potential opportunity for future research is to test the theory of contextual influences on district judges in other policy areas. As discussed in Chapter 3, there are several ways in which salient social or political concerns could impact the content of district judges' decisions. For instance, does income inequality make it more likely that district court judges make rulings favorable to individual litigants in suits against business or wealthy litigants? Does the local legal community's position on tort reform have an impact on judges' rulings for tort plaintiffs vs. tort defendants? The weight of the evidence from this dissertation is that district judges' criminal sentencing decisions cannot be divorced from the environments in which those decisions are made. But it remains to be seen whether or not this conclusion holds for other policy areas.

\section{Conclusion}

In summary, this dissertation has demonstrated that many district judges' sentencing behavior must be viewed in the context of both local attitudes and local conditions pertinent to 
crime and punishment. To scholars who study district courts, and indeed to anybody familiar with the heterogeneity that exists in the United States, this conclusion might hardly seem revolutionary. Few persons would likely be surprised to learn that a district judge living and working in rural Arkansas would approach criminal sentencing differently than a district judge from Chicago. Indeed, past researchers of district courts have generalized district judges throughout the country behave differently due to different "cultures" or different "sociological impacts" (Lynch and Omori 2014; Ulmer 2005; Rowland and Carp 1996).

Still, the findings of this dissertation extend beyond a mere confirmation of regional differences among district judges. Evidence suggests that several district judges have actually altered their sentencing preferences over time in the face of changing conditions. It is this finding that has far-reaching implications for how we understand the role of district judges. If changing facts and circumstances lead many district judges to alter their preferences, then the argument that many trial judges behave pragmatically is bolstered. This finding also calls into question the conception of district judges as behaving solely ideologically (See Sisk and Heise 2012). One of the stronger findings of this dissertation is that the combination of changes to legal rules and judicial partisanship were collectively unable to fully explain variation in district judges' sentencing behavior over time. Instead, judges' preferences changed in the face of changing conditions.

Thus, the broader implication of this dissertation is that proponents of the attitudinal model may be only half-right (See Segal and Spaeth 2002). Consistent with a legal realist conception of judges, individual policy preferences clearly impact the content of decisions. However, at least for district judges in the area of criminal sentencing, those preferences cannot be simply understood in terms of left/right ideology. Other factors, such as preferences of 
salient groups and relevant environmental conditions, also have the ability to impact judicial decisions.

Finally, far from being definitive, the results also raise several new questions. Many of the individual factors studied produced mixed results. In addition, while the findings suggest that different judges will attach different levels of importance to contextual conditions, the extent and nature of those differences remains somewhat of a mystery. Yet as discussed above, these new questions create exciting opportunities to conduct further research and ultimately improve understandings of how district judges make decisions.

\section{References}

Act, Justice, Richard Vigueire, David Keene, Pat Nolan, and Grover G. Norquist. 2015. "Conservative Letters in Support of SAFE Justice Act of 2015." Federal Sentencing Reporter 28(2):135

Baum, Lawrence. 2006. Judges and Their Audiences. Princeton, NJ: Princeton University Press.

Blanck, Peter David, Robert Rosenthal, Allen J. Hart, and Frank Bernieri. 1989. "Measure of the Judge: an Empirically-Based Framework for Exploring Trial Judges' Behavior." Iowa Law Review 75: 653.

Casillas, Christopher J., Peter K. Enns, and Patrick C. Wohlfarth. 2011. "How Public Opinion Constrains the US Supreme Court." American Journal of Political Science 55(1): 74-88.

Cohen, Jeffrey E. 1999. Presidential Responsiveness and Public Policy-Making: The Public and the Policies that Presidents Choose. University of Michigan Press.

Cook, Beverly B. 1977. "Public Opinion and Federal Judicial Policy." American Journal of Political Science 21: 567-600

Enns, Peter. 2014. "The Public's Increasing Punitiveness and Its Influence on Mass Incarceration in the United States.” The American Journal of Political Science. 58(4): 857-872

Epstein, Lee, and Jack Knight. 1998. The Choices Justices Make. Washington, DC: CQ Press.

Epstein, Lee, William M. Landes, \& Richard A. Posner. 2013. The Behavior of Federal Judges. Cambridge, MA: Harvard University Press.

Fischman, Joshua B. \& Max Schanzenbach. 2011 "Do Standards of Review Matter? The Case of Federal Criminal Sentencing." Journal of Legal Studies 40:405-437.

Gibson, James L. 1980. "Environmental Constraints on the Behavior of Judges: A Representational Model of Judicial Decision Making." Law \& Society Review 14:343-370.

Goulden, Joseph C. 1974. The Benchwarmers: The Private World of the Powerful Federal Judges. Random House Inc. 
Hofer, Paul J. \& Mark H. Allenbaugh. 2003. "The Reason Behind the Rules: Finding and Using the Philosophy of the Federal Sentencing Guidelines" American Criminal Law Review. 40: 19-29.

Jones, Bryan D., and Frank R. Baumgartner. 2005. The Politics Of Attention: How Government Prioritizes Problems. University of Chicago Press.

Kautt, Paula M. 2002. "Location, Location, Location: Interdistrict and Intercircuit Variation in Sentencing Outcomes for Federal Drug-Trafficking Offenses." Justice Quarterly 19(4): 633-671.

Kritzer, Herbert M. 1998. Legal Advocacy: Lawyers and Nonlawyers at Work. Ann Arbor: University of Michigan Press.

Kritzer, Herbert. 1978. "Political Correlates of the Behavior of Federal District Judges: A Best Case Analysis." Journal of Politics 40:25-58.

Lynch, Mona and Marisa Omori. 2014. "Legal Change and Sentencing Norms in the Wake of Booker: The Impact of Time and Place on Drug Trafficking Cases in Federal Court." Law and Society Review 48 (2):411-445.

Miceli, Thomas J., and Metin M. Coşgel. 1994. "Reputation and Judicial Decision-Making." Journal of Economic Behavior \& Organization 23(1): 31-51.

Mishler, William, and Reginald S. Sheehan. 1996. "Public Opinion, the Attitudinal Model, and Supreme Court Decision Making: A Micro-Analytic Perspective." The Journal of Politics 58(1):169-200.

Morriss, Andrew P., Michael Heise, and Gregory C. Sisk. 2005. "Signaling and Precedent in Federal District Court Opinions." Supreme Court Economic Review 13: 63-97.

Nardulli, Peter F., James Eisenstein, and Roy B. Flemming. 1988. The Tenor of Justice: Criminal Courts and the Guilty Plea Process. Urbana: University of Illinois Press.

Nicholson-Crotty, Sean, David A.M. Peterson, and Mark D. Ramirez. 2009. "Dynamic Representation(s): Federal Criminal Justice Policy and an Alternative Dimension of Public Mood.” Political Behavior 31(4):629-655.

Peltason, Jack AW. 1971. Fifty-Eight Lonely Men: Southern Federal Judges and School Desegregation. Urbana, IL: University of Illinois Press.

Pew Research Center. 2014. “America’s New Drug Policy Landscape.” Accessible at: http://www.peoplepress.org/2014/04/02/americas-new-drug-policy-landscape/

Posner, Richard A. 1993. "What do Judges and Justices Maximize? (The Same Thing Everybody Else Does)." Supreme Court Economic Review 3:1-41.

Posner, Richard A. 2009. Law, Pragmatism, And Democracy. Cambridge, MA: Harvard University Press.

Posner, Richard A. 2010. How Judges Think. Cambridge, MA: Harvard University Press.

Rowland, C.K. \& Robert A. Carp. 1996. Politics and Judgment in Federal District Courts. Lawrence, KS: University of Kansas Press.

Schauer, Frederick. 2000. "Incentives, Reputation, and the Inglorious Determinants Of Judicial Behavior." University of Cincinnati Law Review. 68:615-647.

Segal, Jefferey A. and Harold J. Spaeth. 2002. The Supreme Court and the Attitudinal Model Revisited. New York: Cambridge University Press. 
Sisk, Gregory C., and Michael Heise. 2005. "Judges and ideology: Public and academic debates about statistical measures." Northwestern University Law Review 99:743.

Silver, Charles and Robert Shapiro. 1984. "Public opinion and the federal judiciary: Crime, punishment, and demographic constraints." Population Research and Policy Review 3:255-280.

Stith, Kate \& Jose A. Cabranes. 1998. Fear of Judging: Sentencing Guidelines in the Federal Courts. Chicago, Il: University of Chicago Press.

Tiede, Lydia B. 2009. "The Impact of the Federal Sentencing Guidelines and Reform: A Comparative Analysis." Justice System Journal 30:34-49.

Ulmer, Jeffery T. 2005. "The Localized Uses of Federal Sentencing Guidelines in Four U.S. District Courts: Evidence of Processual Order." Symbolic Interaction 28: 255.

Ulmer, Jeffery T. \& Mindy S. Bradley. 2006. "Variation in Trial Penalties Among Serious Violent Offenses." Criminology 44:631-670.

United States Department of Justice. 2015. "Prisoners in 2014." Accessible at: http://www.bjs.gov/content/pub/pdf/p14.pdf.

United States Sentencing Commission. 2012. Report on the Continuing Impact of United States v. Booker on Federal Sentencing. Washington, DC: US Sentencing Commission.

United States Sentencing Commission. 2006. Final Report of the Impact of United States v. Booker on Federal Sentencing. Washington, D.C.: United States Sentencing Commission.

United States Sentencing Commission. 1995-2014. Sourcebook of Federal Sentencing Statistics. Accessible at: http://www.ussc.gov/Research_and_Statistics/Annual_Reports_and_Sourcebooks/Archives.cfm.

Vines, Kenneth. 1964. "Federal District Judges and Race Relations Cases in the South." Journal of Politics 26:337-35. 